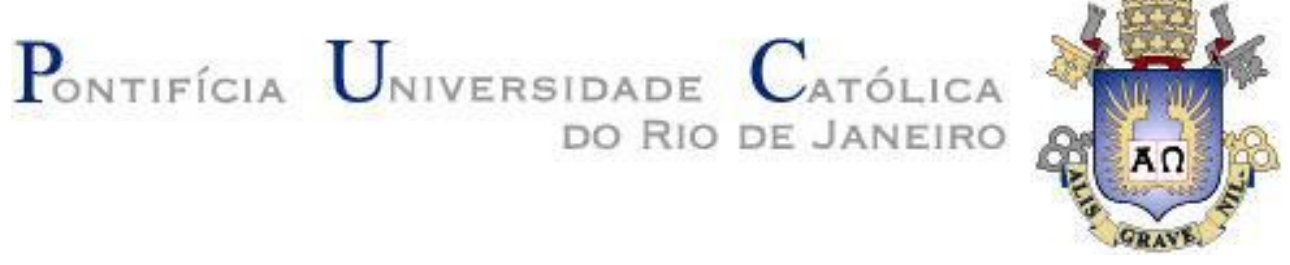

Eliza Martinelli

BAGUNÇANDO AS TEMPORALIDADES: os difusos desenhos temporais da categoria (ex-) criança soldado

Dissertação de Mestrado

Dissertação apresentada ao Programa de Pós-graduação em Relações Internacionais da PUC-Rio como requisito parcial para obtenção do grau de Mestre em Relações Internacionais.

Orientadora: Profa. Marta Regina Fernández Y Garcia Moreno Co-orientadora: Profa. Jana Tabak 


\section{BAGUNÇANDO AS TEMPORALIDADES: os difusos desenhos temporais da categoria (ex-) criança soldado}

Dissertação apresentada ao Programa de Pós-graduação em Relações Internacionais da PUC-Rio como requisito parcial para obtenção do grau de Mestre em Relações Internacionais. Aprovada pela Comissão Examinadora abaixo assinada.

\section{Prof- Marta Regina Fernandéz Y Garcia Moreno \\ Orientadora e Presidente Instituto de Relações Internacionais - PUC-Rio \\ Prof ${ }^{a}$ Jana Tabak \\ Co-orientadora}

Instituto de Relações Internacionais - PUC-Rio

Prof. Roberto Vilchez Yamato Instituto de Relações Internacionais - PUC-Rio

Prof - Rosana Kohl Bines

PUC-Rio

Prof ${ }^{a}$ Elizabete Sanches Rocha Universidade Estadual Paulista - UNESP

Prof. Augusto Cesar Pinheiro da Silva Vice-Decano de Pós-Graduação do Centro de

Ciências Sociais - PUC-Rio 
Todos os direitos reservados. É proibida a reprodução total ou parcial do trabalho sem autorização da Universidade, da autora ou da orientadora.

\section{Eliza Martinelli}

Graduou-se em Relações Internacionais pela Faculdade de Ciências Humanas e Sociais da Universidade Estadual Paulista - UNESP Câmpus de Franca em 2015. Foi pesquisadora e bolsista da Fundação de Amparo à Pesquisa do Estado de São Paulo (FAPESP) e membro do Núcleo de Ensino de Relações Internacionais (NERI), um grupo de extensão que ensinava e aprendia junto a alunos do segundo colegial de uma escola da rede pública.

Ficha Catalográfica

Martinelli, Eliza

Bagunçando as temporalidades: os difusos desenhos temporais da categoria (ex-) criança soldado / Eliza Martinelli; orientadora: Marta Regina Fernández Y Garcia Moreno; co-orientadora: Jana Tabak. - 2018.

172 f.: il. color.; $30 \mathrm{~cm}$

Dissertação (mestrado) - Pontifícia Universidade Católica do Rio de Janeiro, Instituto de Relações Internacionais, 2018.

Inclui bibliografia

1. Relações Internacionais - Teses. 2. Ex-criança soldado. 3. Trauma. 4. Resiliência. 5. (Pós-) conflito. I. Moreno, Marta Regina Fernández Y Garcia. II. Tabak, Jana. III. Pontifícia Universidade Católica do Rio de Janeiro. Instituto de Relações Internacionais. IV. Título. 
Para meu vô Toninho e minha vó Gessy, dois grandes contadores de histórias a quem hoje somente consigo abraçar por meio destas minhas histórias. 


\section{Agradecimentos}

Gostaria, inicialmente, de agradecer tanto à minha família: meu pai Roberto, minha mãe Claudia, minha irmã Sílvia e minha cachorrinha Cléo; quanto ao meu companheiro Matheus pelo amor, carinho, confiança, compreensão e paciência concedidos a mim nos "antes" e "durantes" do mestrado. Afinal, vocês me mostram todos os dias que a melhor forma do amor é aquela que nos (desen)forma e, consequentemente, transborda-nos.

Agradeço, especialmente, minha orientadora Marta Fernández e minha coorientadora Jana Tabak, pelo apoio e confiança; por estarem ao meu lado durante todo este processo e por dedicarem seus precisos tempos e esforços ao meu trabalho. Além disso, um muito obrigado caloroso aos professores: Roberto Yamato, Rosana Kohl Bines e Elizabete Sanches Rocha por aceitarem participar de minha banca de defesa e por me ajudarem na elaboração de minha escrita com seus conselhos e pensamentos.

Agradeço também à PUC-Rio, ao Instituto de Relações Internacionais (IRI) - junto a todos seus funcionários - e à CAPES pelo suporte institucional, financeiro e acadêmico.

Aos amigos e amigas do mestrado que me ajudaram nos processos de mudança, adaptação e transformação no Rio de Janeiro; muito obrigada pela presença, amor e carinho de todos, pelos nossos encontros e nossas conversas dentro e fora do IRI. Agradeço a Vinícius Santiago pelo acolhimento e amizade; a Laís Ramalho pelo carinho e companheirismo; ao Yuri, Marcelle, Luciana e Pedro Maia por compartilharmos discussões, angústias e risadas durante as diversas disciplinas do nosso eixo; a Thais, Ricardo, Luiz, Bruna, Pedro Melo, Sofia e Lucas pelas reflexões instigantes e por participarem e pertencerem a este meu momento único de carinho e aprendizagem

Aos meus avôs e avó: Toninho, Zébio e Gessy pelas memórias, estórias e lembranças que até hoje me fazem presença. E a minha querida avó Cida, pela companhia e pelo sorriso nos momentos de brisas e de tempestades. Sou grata a todos meus familiares, tios, tias, primos e primas que me aconselharam e me ampararam, de alguma forma, ao longo de minha escrita.

De igual maneira, agradeço aos meus amigos (des)de sempre, Viviane Faion e Murilo Bruno que são/estão presentes, mesmo quando distantes. Às pessoas especiais e únicas que entraram e permaneceram em meu caminho, plantando amor e paz: Larissa Heise, Seu Dorival, Ana Maria, Bete, Laura e Caio Furtado.

Muito obrigada a todos! 


\section{Resumo}

Martinelli, Eliza; Moreno, Marta Regina Fernández Y Garcia; Tabak, Jana. Bagunçando as temporalidades: os difusos desenhos temporais da categoria (ex-) criança soldado. Rio de Janeiro, 2018. p. 172. Dissertação de Mestrado - Instituto de Relações Internacionais, Pontifícia Universidade Católica do Rio de Janeiro.

O principal objetivo deste trabalho é discutir e problematizar o modo como a categoria ex-criança soldado vem sendo formada e projetada dentre os discursos do trauma e da resiliência que traduzem o seu prefixo temporal 'ex' por meio certos esquecimentos (temporais e subjetivos) e superação. Desse modo, o ideal para a reintegração social bem-sucedida das ex-crianças soldado está inscrito na possibilidade de superação do passado militar e na projeção de um futuro estável. Além disso, penso ser a relação desta produção temporal entre passado militar traumático e futuro do sujeito resiliente para ex-criança soldado que revela as construções do entendimento de sua categoria no presente como em uma posição de espera. Espera no sentido tanto de aguardo (da criança que espera pertencer ao mundo adulto) quanto de esperança (da ex-criança soldado que espera ser resiliente). De outro lado, questionando a produção do tempo como linear, junto com a relação, essencialmente, opositora entre os discursos do trauma e da resiliência, pretendo refletir sobre as (des)continuidades temporais entre a categoria (ex-) criança soldado, o envolvimento militar e o (pós-) conflito, que marcam seus desenhos temporais difusos. Assim, o parêntese que guarda o prefixo 'ex' traduz uma forma de abranger as múltiplas temporalidades que coexistem nas histórias e estórias das (ex-) crianças soldado e bagunçam com a noção moderna da infância e do conflito armado. A categoria (ex-) criança soldado e sua posição temporal confusa, portanto, incomoda certos binarismos, como: adulto e criança; guerra e paz; público e privado, etc.

\section{Palavras-chave}

Ex-criança soldado; trauma; resiliência; (pós-) conflito. 


\section{Abstract}

Martinelli, Eliza; Moreno, Marta Regina Fernández Y Garcia; Tabak, Jana. Messing temporalities: the diffuse temporal drawings of the (former) child soldier category. Rio de Janeiro, 2018. p. 172. Dissertação de Mestrado Instituto de Relações Internacionais, Pontifícia Universidade Católica do Rio de Janeiro.

The central aim of this work is to discuss and problematize the way that the former child soldier category has been formed and projected into the trauma and resilience discourse, translating the temporal word "former" through certain forgetfulnesses (temporal and subjective) and overcoming. The ideal plan for the successful social reintegration of former child soldiers lies in the possibility of overcoming the military past and of projecting a stable future. Besides, I think that the relation of this temporal production between military and traumatic past and the future of the resilient subject reveals the constructions for understanding the former child soldier category in the present as in a waiting position. The waiting position, in this sense, refers to the Portuguese word espera, which means both "wait" (the child who waits to become an adult) and "hope" (the former child soldier who hopes to be resilient). On the other hand, I intend to think about the temporal (des)continuities among the (former) child soldiers, the military involvement and the (post-) conflict, which define the category's diffuse temporal drawing, by questioning the linear production of time and the mainly oppositional relation between the trauma and the resilience discourses. Thus, the parentheses in the word "former" translate a manner of embracing the multiples temporalities which coexist inside the (former) child soldiers' stories and mess up the modern notion of childhood and armed conflict. On that account, the former child soldier category and its confused temporal position are able to disturb some binarisms, such as adult and child; war and peace; public and private, etc.

\section{Keywords}

Fomer child soldier; trauma; resilience; (post-) conflict. 


\section{Sumário}

1 Introdução 13

1.1 (Des)começos 13

1.2 (Ex-) criança soldado como categoria temporal 16

1.3 Os "entres" do tempo: os discursos do trauma e da resiliência $\begin{array}{ll}\text { para a ex-criança soldado } & 20\end{array}$

1.4 Histórias e estórias de (des)encontros: os difusos desenhos temporais da (ex-) criança soldado 29

1.5 Disposição e conteúdo dos capítulos 35

2 Ser (ex-) criança soldado: desvios e possibilidades 38

2.1 Introdução 38

2.2 A categoria (ex-) criança soldado: o ser em suspensão 41

2.2.1 Quem é a (ex-) criança soldado para o internacional? 43

2.2.2 (Ex-) criança soldado como novo "problema" global 51

2.2.3 Ex-criança soldado e (pós-) conflito: o discurso do retorno 61

2.3 Descaso e amparo: a infância temporal moderna e a posição de espera da criança $\quad 66$

2.3.1 As múltiplas temporalidades e o ser (ex-) criança soldado 72

2.3.2 As histórias e estórias de (des)encontros: a conjugação de ex-crianças soldado no (pós-) conflito 76

2.4 Concluindo: os ventos do tempo 83

3 Passado e futuro: os discursos do tratamento do trauma e da resiliência para a ex-criança soldado 85

3.1 Introdução $\quad 85$

3.2 Ex-crianças soldado como traumatizadas 88

3.2.1 O passado militar: o envolvimento no singular 92

3.3 Ex-crianças soldado como resilientes 100 
3.4 A (re)produção do discurso do trauma e da resiliência para ex-criança soldado

3.4.1 Handbook of resilience on children of war

3.4.1.1 Capítulo sexto: When children become killers: child soldiers in the civil war in Sierra Leone

3.4.1.2 Capítulo sétimo: The fallacy of the ticking time bomb: resilience of children formerly recruited into armed forces and groups

3.4.1.3 Capítulo oitavo: Children of war in Colombia and Iraq

3.4.2 IASC Guidelines on Mental Health and psychosocial support in emergency settings

3.4.3 Muito Longe de Casa: memórias de um menino-soldado

3.5 Os três em um e o um em muitos: questionando a categoria ex-criança soldado

3.6 Concluindo: as asas nas tempestades

4 No traço da espera: a produção do presente para a categoria ex-criança soldado

4.1 Introdução

4.2 A posição incômoda da ex-criança soldado no presente

4.2.1 A infância temporal moderna: a criança que espera

4.2.2 Para além do binarismo ser e tornar-se: (des)continuidades temporais

4.3 A interrogação que se mantem: os desenhos temporais difusos das (ex-) crianças soldado

4.4 Concluindo: bagunçando as temporalidades

5 Considerações Finais: os "entres" temporais e as estórias das ex-crianças soldado 


\section{Lista de Sigla}

AS Assembleia Geral das Nações Unidas

CDC Convenção dos Direitos das Crianças

CPI Corte Penal Internacional

CS Conselho de Segurança das Nações Unidas

DDR Desarmamento, Desmobilização e Reintegração

FAA Forças Armadas Angolana

IASC Inter-agency Standing Committee

OI Organização Internacional

OIT Organização Internacional do Trabalho

ONG Organização não-governamental

ONU Organização das Nações Unidas

OPAC Optional Protocol to the Convention on the Rights of the Child on Armed Conflict

PTSD Post-traumatic stress disorder

RI Relações Internacionais

RUF Revolutionary United Front

UNICEF United Nations Children's Fund 


\section{Lista de Figuras}

Figura 1 - Imagem da produção do filme Johnny Mad Dog, 2008

Figura 2 - Foto do ensaio The rape of a Nation de Marcus Bleasdale, 2008

Figura 3 - Criança síria fotografada por Osman Sagirli (2012)

Figura 4 - Ex-crianças soldado da Libéria. Foto da Polka Magazine, 2013

Figura 5 - Exemplo de questionário sobre trauma destinado às ex-crianças soldado

Figura 6 - Foto de uma menina soldado encontrada no livro Child Soldiers de Leora Kahn (ed.), 2008

Figura 7 - Foto do livro Child Soldiers de Leora Kahn (ed.), 2008

Figura 8 - Ishmael Beah dando palestras na República Central Africana, 2012 
Uns, com os olhos postos no passado, Veem o que não veem: outros, fitos Os mesmos olhos no futuro, veem O que não pode ver-se.

Por que tão longe ir pôr o que está perto A segurança nossa? Este é o dia, Esta é a hora, este o momento, isto É quem somos, e é tudo.

Perene flui a interminável hora Que nos confessa nulos. No mesmo hausto Em que vivemos, morreremos. Colhe O dia, porque és ele.

Odes, Ricardo Reis 


\section{1 \\ Introdução}

1.1

(Des)começos

Nestes primeiros momentos, eu me deparo com a dura tarefa de trazer em letras algum começo, o qual sempre me toma emprestado rimas e vidas de páginas e vozes alheias, sendo nem de longe um enredo isolado ou uma ruptura do acaso ajeitada nos meus primeiros pares de linhas. Há continuações entre as muitas histórias e estórias: são (des)começos, eu digo; mostram os outros mundos que intermedeiam estas nossas miradas. Qualquer início, por isso, sempre me parece mais difícil. Traduzir todos os milhões de pensamentos que vagam em minha mente - não desejosos de fazerem algum sentido - e jogá-los em uma folha com margem e espaçamento definidos para que ali, naquele espaço outrora branco, as palavras possam se aninhar e compartilhar alguns e, ao mesmo tempo, vários sentidos. É um grande drama com enredo misterioso, digo isto como pesquisadora e também como poetisa. Amontoar rimas e vindas não é um processo fácil, pois é necessário sempre se (re)encontrar, por algum momento, com aqueles vários outros em nós mesmos.

Prefiro, assim, começar aguçando o sentido da audição, fechando os olhos e me embalando ao som da música de Emmanuel Jal, um ex-menino soldado sudanês, recrutado pelo Exército Popular de Libertação do Sudão, quando tinha sete anos de idade, e que hoje se destaca internacionalmente como cantor de hip hop. Em uma de suas músicas mais conhecidas Warchild ${ }^{1}$, Emmanuel Jal traz suas experiências como (ex-) menino soldado ao dizer que "I was forced to be a war child [...] I am a war child" (Jal, 2008) e, juntamente, "I believe I've survived for a reason: to tell my story to touch lives". (Jal, 2008).

Nos enquadramentos dos jogos verbais em que o cantor se encontra e permanece como criança da guerra, há alguns movimentos específicos e ambíguos que orientam seu tornar-se e seu ser, tanto em relação à criança soldado quanto à ex-criança soldado e também ao modo como ele percebe sua sobrevivência na adultez. Dessa maneira, percebo que é entre o passado militar e o futuro do mundo

\footnotetext{
${ }^{1}$ Primeira faixa do álbum também intitulado Warchild de 2008.
} 
adulto que as relações produzidas nos discursos do trauma e da resiliência ${ }^{2}$ para a ex-criança soldado orbitam a partir da produção do sujeito resiliente capaz de contar sua história de superação. Os entornos da ex-criança soldado no presente, por entre esses discursos, parece marcar um fim com tons de (re)começo, desvios e possibilidades entre o passado militar traumático e o futuro resiliente que permanecem em dúvidas e interrogações. Em tons passivos e ativos, a canção vai construindo as possibilidades de se conhecer a categoria (ex-) criança soldado por meio de conjugações dos tempos verbais entre o passado militar e o presente do adulto resiliente que agora narra sua história de infância. Os arranjos temporais entre superação e esquecimentos mostram os entornos silenciados da categoria excriança soldado entre uma ideia de criança soldado, uma percepção do envolvimento militar e uma concepção de resiliência que vêm junto ao prefixo 'ex'.

Neste sentido, busco, neste trabalho, (des)envolver como a concepção da categoria (ex-) criança soldado vem sendo construída e como, igualmente, movimenta singulares noções de temporalidade pelos atos de fala e pelos silêncios, atrelando esquecimentos ${ }^{3}$, superação e estabilidade em uma mesma narrativa. Além disso, tentarei navegar por entre os desvios e possibilidades concedidos às ex-crianças soldado nos discursos do retorno, principalmente, aqueles do trauma e da resiliência, no processo de retorno à vida social, analisando o dito sobre o caminho específico para a volta da estabilidade seja física, mental, emocional e social destas crianças. Desse modo, os discursos do trauma e da resiliência para a ex-criança soldado e também suas relações ambíguas funcionam como justificativas capazes de desenhar um passado militar (essencialmente negativo) a ser (re)configurado e um futuro estável no mundo adulto a ser esperado.

As narrativas tradicionais sobre os estudos de crianças afetadas pela guerra mantêm, em sua maioria, uma perspectiva de tratamento altamente medicalizada com ênfase em terapias individuais, ressaltando que "war experience is characterized as an illness that must be cured, with children presented as broken." (Guyot-Diangone, 2012, p. 1, itálico no original).

\footnotetext{
${ }^{2}$ Tais discursos não são apresentados de forma coesa e singular, por isso, tentarei (des)apontar suas produções por meio da análise de três textos apresentados mais adiante.

${ }^{3}$ A minha ideia de esquecimento está atrelada também ao discurso de qual superação é esperada para a ex-criança soldado e qual passado deve ser (re)configurado a fim de se ter um futuro desejável. Também correspondendo à dificuldade da sociedade adulta em traduzir as histórias do passado militar que estão em descompasso com a do ser resiliente que conta sobre sua sobrevivência.
} 
Esta visão das ex-crianças soldado como, primeiramente, traumatizadas e do passado militar como, essencialmente, negativo esconde muitas outras histórias e narrativas sobre as plurais experiências da (ex-) criança soldado no (pós-) conflito e sobre seus relacionamentos interpessoais desenvolvidos e mantidos durante o envolvimento com o grupo armado ${ }^{4}$. Além disso, estes discursos do 'estar traumatizadas' tendem a passar uma condição de passividade e vitimização da excriança soldado como enferma em necessidade de tratamento médico que, em contrapartida, é questionada pelos discursos da resiliência, cujo foco está na capacidade da criança em se recuperar, em adaptar-se e lidar com esses eventos traumáticos.

Estando majoritariamente em oposição, os discursos do trauma e os da resiliência para a ex-criança soldado parecem movimentar ideais específicos de superação e de estabilidade junto aos processos de reintegração social; sendo a partir dessas contraposições e incompatibilidades que a categoria ex-criança soldado expressa suas temporalidades entre a escolha de um passado militar que a define e de um futuro adulto que a espera.

Exemplifico este ponto com uma das recomendações ao livro de Chandi Fernando e Michel Ferrari (2013) em que LGen Roméo Dallaire ${ }^{5}$ deixa suas impressões acerca do conteúdo da obra, destacando a posição de vulnerabilidade do ser criança (concepção moderna sobre infância) no conflito armado moderno. Tal visão relaciona-se, de certa forma, a possibilidade de conceber a distância das experiências passadas (do envolvimento militar) como forma de solução para um futuro melhor e de projetar as crianças como mais flexíveis e, assim, mais capazes de ser resilientes.

My friend Emmanuel Jal says he believes he has survived for a reason - to tell his story, to touch lives. It is remarkable how children, the most vulnerable in conflict, are able to transcend the worst evils this world has to offer. The authors of this book recount positive stories of struggles for survival and the remarkable journeys of young people who refused to let their adverse circumstances dictate their future possibilities. (Dallaire, 2013, p. v).

\footnotetext{
${ }^{4}$ Neste trabalho, utilizo o termo grupo armado para falar tanto das forças armadas estatais quanto de grupos armados não-estatais.

${ }^{5}$ Roméo Dallaire é fundador da Iniciativa Roméo Dallaire sobre Criança Soldado, uma parceria global com a missão de acabar com o recrutamento e uso de crianças soldado. Além disso, o General Dallaire é um conselheiro do governo canadense e também da ONU.
} 


\section{2}

\section{(Ex-) criança soldado como categoria temporal}

Quando comecei a investigar com mais profundidade as crianças soldado e suas histórias, eu me sentia confusa acerca dos caminhos que deveria seguir e de como lidar com as desconfortantes impressões que os textos iam deixando em mim. Foi então que, durante um encontro de família, minha tia me perguntou sobre o que se tratava o meu trabalho de pesquisa. No fim de tal pergunta, senti, ao meu redor, vários olhares curiosos que esperavam de minhas futuras palavras o conforto do entendimento fácil e da resposta instantânea no mesmo tom da pergunta, capaz de embalar, prontamente, meu argumento em uma bela caixa de presente. Eu tenho certeza de que a decepcionei naquele dia, como outras pessoas, amigos e parentes que me dirigiram a mesma pergunta em outros momentos. Eu me sentia intraduzível, não tinha a intenção de simplificar a complexidade daquilo em mim, mas, ao mesmo tempo, o silêncio da incompreensão parecia gerar um tédio social.

Depois de alguns pensamentos silenciosos, resolvi responder somente 'criança soldado', porém, o interessante foi notar a estranheza nas faces de meus familiares que, por desconhecerem a definição do conceito, também não se sentiam confortáveis em fazer associações entre os sentidos das duas palavras. A distância invisível construída em nosso imaginário moderno entre a criança e o soldado esculpiu dúvidas e confusões nos semblantes dos que me cercavam. Enquanto esperava de mim uma posterior explicação, minha tia parecia suplicar internamente pela coerência dos sentidos que ali joguei, eram sentimentos como pena e medo que se misturavam em seu olhar relutante. Deixei-a assim como eu estava - banhada em dúvidas e perguntas - e, naquele momento, conseguimos de certa forma nos entender, pois compartilhamos o desconforto da não resposta.

Após alguns anos, similares incômodos me encontraram de novo e me trouxeram o prefixo 'ex', ou melhor, fizeram-me pensar na categoria do passado, de algo que já foi, mas que, ao mesmo tempo, ainda risca o nome. A ex-criança soldado, além do desconforto entre juntar criança e soldado em uma mesma concepção, tenta alocar, igualmente, esta disputa de definições, ambiguidades e experiências que definem uma criança soldado no passado, no tempo a ser superado e no futuro da estabilidade e do ser resiliente. É neste jogo temporal específico, 
entre o passado do envolvimento militar e o futuro do sujeito resiliente, em que são mobilizados os discursos da reintegração social para a agora ex-criança soldado, a fim de se localizarem nesses discursos o reflexo do soldado no 'ex', o da criança no agora para que seja possível preparar o adulto que está por vir.

Pautando-me nestas relações, meu principal objetivo nesta pesquisa é refletir sobre e problematizar o modo como a categoria ex-criança soldado vem sendo formada e projetada pelo discurso do retorno (processos destinados à reintegração social), principalmente, os discursos do trauma e da resiliência, cujo ideal está na superação do passado militar e na projeção de um futuro estável. Ou seja, debruçome também por entre os desvios e as possibilidades produzidos para a ex-criança soldado como categoria, capazes de acomodar, sob a temporalidade moderna ${ }^{6}$, certas lembranças e projetos como ideais, enquanto outras histórias e estórias ${ }^{7}$ são silenciadas.

Passado e futuro são tempos articulados e divididos por meio de, respectivamente, superação e estabilidade e também entre uma concepção de trauma e outra de resiliência, sendo importantes no desenho temporal da categoria ex-criança soldado e na suspensão do ser no presente. Sendo assim, minha proposta é trazer o conceito de $e s p e r a^{8}$ no intuito de traduzir a peculiar posição da ex-criança soldado no presente, uma vez que os dois significados do termo - aguardo e desejo - são capazes de, simultaneamente, relacionar a continuidade e a ambiguidade de ser junto com o anseio e a aspiração para o futuro.

Por conta disso, penso ser a relação desta produção temporal entre passado militar traumático e futuro do sujeito resiliente para ex-criança soldado que revela as construções do entendimento de sua categoria no agora e dos movimentos que o contar de uma história possibilita. Ou seja, considero que tais percepções sobre as divisões temporais são capazes de estabelecer diferentes sujeitos traduzidos por meio de certas memórias e planos. Nessas alocações temporais, o ser ex-criança

\footnotetext{
${ }^{6} \mathrm{~A}$ temporalidade moderna se refere à produção linear entre passado, presente e futuro junto a suas divisões demarcadas. Ou seja, o passado, presente e futuro são projetados como blocos temporais específicos e diferentes entre si.

${ }^{7}$ Por definição, na língua portuguesa, histórias são entendidas como o real relato de um evento, enquanto que as estórias são narrativas ficcionais, contos ou fábulas com a finalidade de entretenimento, contudo, atualmente, o uso do termo 'estória' não mais é recomendável pela Academia Brasileira de Letras, retirada dos principais dicionários. Todavia, utilizo as duas em separado a fim de questionar a construída e ficcional fronteira entre fatos e ficção e também destacar as simultaneidades e ambiguidades que formam suas produções.

${ }^{8} \mathrm{O}$ conceito de espera em relação à infância já é algo discutido pelos Estudos da Infância, reflexões que explorarei melhor no quarto capítulo.
} 
soldado continua em espera, respirando entre idas e vindas do ontem e do amanhã, do trauma e da resiliência. Na linear temporalidade moderna,

[...] a memória do passado e a confiança no futuro foram até aqui os dois pilares em que se apoiavam as pontes culturais e morais entre a transitoriedade e a durabilidade, a mortalidade humana e a imortalidade das realizações humanas, e também entre assumir a responsabilidade e viver o momento. (Bauman, 2000, p. 163).

Sob este prisma, alguns dos questionamentos que me guiam e me guiarão nestas linhas vão ao encontro de com minha intenção primária aqui: refletir sobre e, ao mesmo tempo, questionar as construções da ex-criança soldado como uma categoria suspensa no presente e inserida em uma específica narrativa do 'estar traumatizada' e/ou 'ser resiliente'. Isto é, meu objetivo é 'bagunçar' ontologias ao questionar, principalmente o que é esperado de uma ex-criança soldado.

A partir das dadas respostas certas, das dúvidas, dos suspiros e dos silêncios que possam resultar dessa pergunta, outras perguntas aparecem e algumas permanecem caladas. Quem pode ser uma ex-criança soldado? Como se dá esta categorização? Essas perguntas estão em constante disputa; mesmo que haja um esforço de transparecer um ar de fixidez e coerência por entre os discursos que as formam, as entranhas do ser e a produção da categoria ex-criança soldado são jogadas em voz ativa (entre aspas) e passiva. As confusões de seu existir criam espaços e tempos específicos para a sua tradução, ou melhor, o aparecimento e a camuflagem da categoria ex-criança soldado por entre os discursos do retorno (re)produzem um certo entendimento e sentido para suas histórias, estórias e identidades. Portanto, a posição temporal da ex-criança soldado não é afirmação, mas sim, uma constante interrogação.

$\mathrm{Na}$ continuidade de minha escrita, deparei com uma literatura escassa sobre a relação entre criança soldado e ex-criança soldado junto às desenvolturas (também temporais) do conflito e do envolvimento com o grupo armado. A ex-criança soldado se encontra camuflada nas entrelinhas dos discursos do retorno à vida civil, sendo que, como categoria, não recebe devida atenção em comparação à análise das crianças soldado, ou melhor, da criança recrutada por um grupo armado oficial ou não-estatal ${ }^{9}$, ainda que este tema também já seja caracterizado como marginal

\footnotetext{
${ }^{9} \mathrm{O}$ conceito de criança soldado foi substituído por criança associada a uma força armada ou grupo armado pelos Princípios de Paris em 2007, porém, neste trabalho, continuo trabalhando com o conceito criança soldado, mais especificamente, quando o prefixo temporal 'ex' entre em cena a
} 
dentro dos estudos tradicionais de Relações Internacionais. Marginalizado por conta, principalmente, de seu desvio aos temas principais da disciplina (ex: Estados, sistema internacional, etc.) e também da problemática ideia de uma infância universalmente entendida pela vulnerabilidade e inocência do ser criança (apresentada, internacionalmente, pela Convenção dos Direitos da Criança) que dispensa discussão e questionamento. (Macmillan, 2009). Destarte, neste cenário, a categoria ex-criança soldado parece estar mascarada no mesmo dilema entre o fim e o (re)começo da infância e da criança soldado que permite um virar de olhos quando questionada.

De outro lado, acredito que conseguir, simultaneamente, separar, unir e inverter a criança soldado e a ex-criança soldado e suas relações temporais difusas envolvem funções e inclusões, negações e permissões capazes de bagunçar uma fixa ideia de infância moderna (ocidentalizada) e do conflito armado moderno (nãoocidental) que estão em jogo. Além de desmontar o quebra-cabeça das posições das categorias entre passado, presente e futuro, ou seja, a ex-criança soldado como categoria está em constante disputa entre os tempos verbais que caracterizam uma criança soldado, rearticulando histórias, comportamentos e respostas esperados. Sendo assim, conceder porosidade e ambiguidade na análise crítica dessas categorias incentiva estudos e práticas em prol de um maior reconhecimento de peculiaridades e ambivalências da ex-criança soldado e suas histórias e estórias.

Em virtude disso, pretendo englobar, em outro ponto, os discursos que complexificam a infância e o ser criança, trazendo a categoria ex-criança soldado para o palco ao destacar suas produções e seus significados por entre os discursos que a produzem. Faz-se mister também ressaltar que o silêncio e a ausência de estudos críticos que envolvem a (re)produção desta categoria somente a escondem mais dentro dos significados espaciais e temporais estabelecidos de entendimentos possíveis para a criança soldado como desviante da infância inocente e pertencente somente à realidade do conflito moderno, acomodando-a dentro de um discurso tradicional limitado.

Desse modo, incomodar as bases temporais e a produção da categoria (ex-) criança soldado pode contribuir para bagunçar as imagens construídas da criança normal e da desviante e também do passado, presente e futuro que orientam as

fim de questionar o distanciamento entre o mundo da infância moderna e do conflito armado moderno e entre passado e futuro. 
conjugações verbais do ser. Por este motivo, reafirmo a importância de problematizar a formação de categorias e conceitos que norteiam nossa mirada à realidade, pois, ao questionar os discursos produzidos e produtores da categoria excriança soldado, as promessas e esperanças do “crescer para poder ser" são também incomodadas, refletindo a ambiguidade e porosidade de se pensar nossos tempos e temporalidades além da linear divisão entre passado/presente/futuro.

A partir dessas produções de categorias e definições, as narrativas e histórias das (ex-) crianças soldado vão sendo contadas e recontadas pelas linhas que traduzem uma certa concepção de infância e também de adultez, do público e do privado, do conflito e da paz, sendo válido enfatizar que, neste trabalho, minha escolha é seguir com o conceito de (ex-) criança soldado para transparecer o incômodo dos significados conflitantes e da alocação do ser na temporalidade moderna pelo prefixo 'ex'.

O choque e o impacto causados quando juntamos os termos 'criança' e 'soldado' e depois o prefixo 'ex' conseguem mostrar como certos discursos são (re)produzidos e como determinadas relações sociais e histórias são tidas como inquestionáveis pelas ações e atuações do internacional. Logo, reconheço a relevância de colocar em dúvida certos conceitos e significados que moldam os discursos, visto que é na percepção crítica da linguagem que as vozes e os silêncios se misturam, produzindo conceitos, relações sociais e subjetividades. Neste caso, entre os desvios e possibilidades do ser ex-criança soldado e de sua alocação temporal.

\section{3 \\ Os "entres" do tempo: os discursos do trauma e da resiliência para a ex-criança soldado}

Storms only come for a while. Then after a while they'll be gone.

Emmnuel Jal, Warchild.

Na duração desta sentença, penso na construção do tempo. Quando criança, eu achava que o tempo era a força invisível que movia os ponteiros dos relógios, todos juntos em um mesmo compasso ritmado. Poderia ser o relógio de pulso do meu pai ou o da parede da cozinha da minha avó, todos apontavam para o mesmo lugar no mesmo instante. Magia bonita de se ver! Contínuo compasso que se 
construía sem, muitas vezes, ser percebido. Movimento constante com emoção e determinação. Sentia o tempo, portanto, como igual ao vento, vinha bagunçando os meus cabelos e os alheios, remexendo e chacoalhando os ponteiros dos variados relógios.

Era do tic ao tac, dos segundos às horas, que o tempo me ganhava alguma forma. Aos meus olhos, a mecânica simplificada da questão: “ que horas são? ” era mais enigmática do que se apresentava; como eu poderia adivinhar quem ou o que era capaz de mudar as horas? Com o que o tempo se parecia? A resposta numérica era séria e não me satisfazia.

Quando escutei a história dentro da mitologia grega sobre Atlas, o homem que sustentava o peso do mundo nas costas, pensei que o tempo poderia ser um homem idoso, um tempo masculinizado com tempo para poder ser tempo, o qual, sem poder ser visto, movimentava todos os ponteiros no mesmo instante. Ele era a força e o poder capaz de ditar o movimento das horas e, por consequência, dos seres humanos, já que todos faziam do tempo alguma vida florescer. Minha avó olhava o relógio enquanto mexia, freneticamente, as panelas que borbulhavam seus temperos, o fogo deveria estar desligado antes das doze horas para o almoço. O único patrão do meu pai fora seu relógio de pulso, ele o via na tentativa de confirmar sua intuição, seja a fim de começar ou de acabar seu expediente. São esses tempos que me formaram e deformaram, que ganham passo e compasso por entre minhas vivências, sendo materializados nas histórias, nas rotinas, nos (des)encontros, nos sentimentos e nos comportamentos...

O tempo e as temporalidades que se mesclam nas histórias e estórias não são homogêneos, trazem linhas que pluralizam os eventos e fazem os momentos se conhecerem para além da contagem das horas. A construção das memórias, do agora e das esperanças se conectam por meio de um certo imaginário temporal moderno representado, metaforicamente, pelo compasso dos ponteiros. Minha intenção aqui também é problematizar a construção do tempo moderno que estipula um caminho linear e unificado de se pensar sobre superação, pois, aqui me encontro pluralizando a disposição dos eventos e a alocação temporal das ex-crianças soldado nos discursos que as tratam ora como traumatizadas, ora como resilientes.

Por isso, com o objetivo de explorar os dizeres sobre a produção da (ex-) criança soldado como categoria, através das relações entre os discursos do trauma e da resiliência, analisarei aqui três textos. O primeiro, intitulado Handbook of 
Resilience in Children of War (2013), foi elaborado por Chandi Fernando e Michel Ferrari - estudiosos do campo da "Psicologia aplicada e Desenvolvimento humano" na Universidade de Toronto - por meio de uma compilação de escritos dos vários contribuintes do volume. O objetivo do trabalho supra é estudar as crianças e jovens que demonstraram notável resiliência perante as experiências da guerra. $\mathrm{O}$ segundo texto - Iasc Guidelines on Mental Health and Psychosocial Support in Emergency Settings (2007) - representa um guia, também utilizado pela UNICEF, para ajudar os trabalhadores humanitários a lidarem com populações em tempos de crises de modo a reforçar o bem-estar, a dignidade e a resiliência. (UNICEF, 2011). Finalmente, o terceiro texto - "Muito longe de casa: memórias de um meninosoldado" de Ishmael Beah - é um livro publicado em 2006, que traz a história das memórias do autor como menino soldado em Serra Leoa.

São três textos que mobilizam diferentes tipos de escritas e propostas, mas que se interligam nas dinâmicas das relações e repostas estabelecidas para a excriança soldado. Para a análise dos discursos desses textos, respaldo-me numa concepção tanto social quanto política da linguagem, uma vez que ela se mostra capaz de mobilizar sujeitos, objetos, estruturas materiais e relações sociais ao produzir e reproduzir determinadas subjetividades e identidades. "Language is social and political, an inherently unstable system of signs that generate meaning through a simultaneous construction of identity and difference." (Hansen, 2006, p. 15). Neste sentido, percebe-se que através da linguagem as identidades que dão base ao discurso político são produzidas e, simultaneamente, são (re)produzidas por tais discursos, ou seja, "they are simultaneously (discursive) foundation and product." (Hansen, 2006, p. 19).

Por isso, parto da visão de que materialidade e ideias são construídas através do discurso, isto é, a realidade material tem importância, encontrando-se sempre mediada discursivamente, pois o discurso incorpora ambos: fatores ideacionais e materiais. Ademais, é importante reconhecer que, por mais que os discursos produzidos tentam fixar um determinado significado sob uma estrutura, transparecendo um ar de fixidez, eles serão sempre instáveis e não previsíveis. (Hansen, 2006). A categoria ex-criança soldado vem sendo (re)produzida e fixada por meio de determinados discursos, dentre outros, por entre aqueles que a qualificam como traumatizada e/ou resiliente, ajeitando sua posição temporal e suas 
histórias ao trazer um entendimento unificado e 'automático' do envolvimento militar como, essencialmente, negativo.

A partir desta dinâmica, fixar um entendimento específico para a categoria ex-criança soldado camufla as relações de poder que movimentam a maneira como os discursos acerca do trauma e da resiliência são apresentados e estudados. Estando em deslocamentos, repetições e sobreposições, a relação entre os discursos da resiliência e do trauma, no que tange à formação da categoria ex-criança soldado, mostra-se capaz de guiar discursos de multiplicidades, ambiguidades, fragmentos e heterogeneidade, mesmo que os interesses que a apoiam estejam voltados para a (re)produção e manutenção de certa estabilidade social - neste caso, futura.

Assim, creio ser possível questionar: qual relação é fixada para a (re)produção do sujeito traumático e do modo de se pensar a resiliência? Isto é, pretendo problematizar a maneira pela qual o discurso da resiliência se manifesta, seja pela superação da memória do trauma ou pela (re)produção do evento traumático ou ainda pela ideia do retorno a uma infância idealizada. Nestes escritos, portanto, critico esta 'natural' relação entre os discursos do trauma e os da resiliência que produzem a categoria ex-criança soldado e oscilam dentre certos esquecimentos e superação, relacionados ao passado militar e ao futuro do adulto.

Ao trazer outras maneiras de mostrar as relações temporais plurais e ambíguas entre a produção do trauma e da resiliência para a ex-criança soldado, consigo, igualmente, perguntar: a projeção do ser resiliente não é, igualmente, um meio de (sobre)viver durante o conflito? Quais são os outros passados e também os outros futuros nas histórias e estórias da ex-criança soldado? O discurso da resiliência não pode ser tratado sob um olhar de enfrentamento e embate das variadas temporalidades que coexistem durante e após o conflito? Como os discursos do trauma e da resiliência colocam o envolvimento militar da ex-criança soldado no passado?

Dessa forma, busco trazer algumas outras histórias e estórias das ex-crianças soldado passíveis de questionar o tradicional entendimento sobre o (pós-) conflito e sobre seus envolvimentos nos grupos armado. Ou seja, por meio de outros depoimentos - encontrados, majoritariamente, em relatórios de ONGs atuantes na causa, mas também dentro de textos acadêmicos - será possível reconhecer o modo com que outros passados são capazes, igualmente, de desenharem uma diferente concepção de presente. E, assim, problematizando o consolidado discurso temporal 
de rupturas que embasa a relação entre a (ex-) criança soldado e o (pós-) conflito. Indo além da ruptura temporal entre criança soldado e ex-criança soldado, o depoimento abaixo mostra como as dinâmicas temporais são difusas e (des)contínuas.

[The RUF] left a farewell 'gift', an everlasting farewell gift with me ... I am carrying on my breast right now. They wrote 'RUF' on me and they wrote 'AFRC' on me ... What they did to me was calculated on their part. They knew that once they put this brand on me, if I went off to some other place, the people on the opposing side would kill me. That is why they put this on me. They wanted me to always be with them. They wanted to make me incapable of leaving them. That is why they did this to me...It is the most painful part of life right now. [Ex-menina soldado, Serra-Leoa]. (Denov, 2010, p. 165-66).

Essas marcas e rastros deixados pelo (pós-) conflito e pelo envolvimento da criança no grupo armado transparece nas relações temporais confusas e ambíguas entre o prefixo 'ex' da categoria ex-criança soldado e o (pós-) conflito. Suas temporalidades, muitas vezes, díspares, traduzem a dificuldade de manter um olhar temporal linear (e também de rupturas) por entre os eventos narrados, sendo a marca física que permanece no corpo desta ex-menina soldado uma forma capaz de manter um passado militar em constante envolvimento com as experiências do presente. $\mathrm{O}$ passado militar, neste caso, é (re)vivido de outras formas e em outros momentos e a criança traz inscrito em si, de certa maneira, o tempo da guerra.

[...] after the conflict, the individual and collective histories of young people too need to be taken into account in order to disentangle the complex social realities in which violent struggles have occurred and where young people made decisions related to their own involvement in the conflict. (Hanson, 2017, p.283).

Portanto, igualmente entendo que trazer outras vivências e histórias das excrianças soldado possibilita englobar a complexidade das experiências da (ex-) criança soldado no antes, no durante e no após seu envolvimento no grupo armado, além de pensar na construção destes desvios e possibilidades (entre o passado militar traumático e o futuro do ser resiliente) dentro do atual discurso do trauma e da resiliência que formam sua categoria. Estas outras histórias e experiências desconfortam a concepção moderna de infância ao fragmentarem e dispersarem o que se esperava do ser criança (essencialmente inocente) nas divisões do espaço e tempo ou, mais especificamente, nas relações temporais com o (pós-) conflito. 
Neste sentido, a partir do discurso da infância temporal moderna, busco mostrar como a posição temporal da ex-criança soldado é desenhada, principalmente, em relação aos elementos das temporalidades do ser criança que tratam sobre sua posição de espera no presente e a infância como um período temporário e de preparação para a adultez. Por isso, o binarismo presente no campo dos Estudos da Infância ${ }^{10}$ do human being (ser) e human becoming (tornar-se) e suas relações (sejam de oposições, evoluções ou complementariedade) se apresentam, nesta minha proposta, como um fator analítico central para compreender como se dá a concepção da (ex-) criança soldado no momento presente e suas construções temporais plurais e ambíguas.

Este binarismo aloca a posição do ser no presente - como sujeito social, construtor ativamente de sua realidade - e, do outro lado, o tornar-se como uma condição de possibilidade orientada para o futuro, projetando a criança como um adulto em formação, isto é, a criança é apresentada como incompetente em relação ao ser adulto, estando em processo de construção no tempo presente. (Uprichard, 2008). Em virtude disso, a condição da criança individual no presente é de preparação; sendo a infância, portanto, descrita como um período transitório e marcado por mudanças em que a criança vai adquirindo capacidade, competência, maturidade e racionalidade com o propósito de adentrar o mundo adulto com sucesso. (Qvortrup, 2004).

Destarte, como um indivíduo 'em formação', a criança ainda não está integrada na sociedade, sendo sociedade igualada à sociedade adulta, pois, " the type of 'growth' metaphors that are readily adopted in discussions about childhood all pertain to the character of what is yet to be and yet which is also presupposed." (Jenks, 2005, p.8).

De outro lado, estando de acordo com a discussão de Uprichard (2008), igualmente vejo que possuir uma visão dicotômica e opositora entre ser e tornar-se (presente ou futuro, criança ou adulto) se mostra como limitante e problemática, visto que alimenta divisões de competência e temporalidades específicas entre

\footnotetext{
${ }^{10} \mathrm{O}$ interesse em firmar um paradigma acadêmico sobre a infância e as crianças veio no final da década de 1970 com o propósito, primeiramente, de se distanciar do discurso tradicional sobre o tema que trazia a infância como universal e indissociável ao estudo da família. Além disso, inspirados nos argumentos de Phillipe Aries (1962) sobre a construção social da infância, os Estudos da Infância afirmam que as experiências das crianças e jovens são mediadas pela cultura, o que produz uma diversidade de se pensar a infância e trazem a criança como participante da sociedade. (James, 2004).
} 
infância e adultez, em que a criança ora é agente, ora é incapaz, ora é presente, ora é futuro. Desse modo, Jenks (2005) propõe pensar na criança como ambos (human being e human becoming), ou seja, a infância, a vida adulta, o adulto e a criança se encontram sempre na complexa dinâmica do ser e tornar-se, engajando-se com presente e futuro no curso de suas plurais experiências diárias. (p. 308).

Nas entrelinhas dessas 'misturas' e (des)continuidades entre o ser e tornarse, trago o conceito de espera para traduzir o presente da categoria ex-criança soldado, manifestando ideias de aguardo e, ao mesmo tempo, de esperança. O ser ex-criança soldado, codificado nas linhas temporais, está sempre esperando algum momento no presente a fim de ser, por essa razão, a posição da ex-criança soldado nesse tempo apresenta-se como duvidosa e ambígua, caracterizada como o momento entre o passado militar traumático e o futuro do adulto. Portanto, acredito que, nesta análise, "to understand what children are, we do need to understand not only their past, present and future but also the mutable relations and shifting sequences between these temporal orders. "(Hanson, 2017, p. 282).

Durante as (des)contínuas relações temporais da (ex-) criança soldado com o (pós-) conflito e também com o grupo armado, exponho uma análise temporal crítica, que desafia o entendimento linear e fixo do tempo dividido entre passado/presente/futuro. Por isso, a fim de reconhecer a ambiguidade e a pluralidade das temporalidades que coexistem nas histórias e estórias das (ex-) crianças soldado, envolvo-me nas concepções críticas de Shapiro (2016) sobre o tempo, principalmente, através do futuro anterior will-have-been (terá sido) - uma gramática capaz de demonstrar como os eventos do passado são reconfigurados pelo momento presente, obtendo outras relevâncias políticas - ou também pela ideia de que as percepções do tempo e das temporalidades são plurais e coexistem de modo descontínuos por entre os grupos humanos: há múltiplas temporalidades.

Reescrever a noção de temporalidade no texto implica reconhecer o tempo como uma experiência viva situada, historicamente, por entre específicos sujeitos. (Shapiro, 2016 apud Romano, 2014, p. x). Logo, pensar e questionar as fronteiras fluídas da produção do evento e perceber a história do tempo além dos moldes oficiais de narração de um momento podem, igualmente, corresponder com o modo de interrogar a posição temporal da categoria (ex-) criança soldado e as histórias gerais que vão sendo formadas em seu nome entre o passado militar traumático e o futuro resiliente. 
Junto a isto, percebo que minha análise, portanto, consegue se abrir para o diálogo com outras disciplinas e transborda o tom tradicional dos estudos dentro da área de Relações Internacionais, trazendo temáticas e conceitos poucos trabalhados ou, majoritariamente, excluídos de seus marcos disciplinares. Ou seja, ao me envolver na discussão sobre a produção discursiva da categoria ex-criança soldado - a partir de análises temporais, estéticas e subjetivas sobre ideias de resiliência e de infância, por exemplo - apresento outras formas de contar histórias e estórias e de mostrar os questionamentos e críticas sobre conceitos, significados e discursos.

De igual maneira, gostaria, neste momento, de destacar que os discursos da resiliência que formam a categoria ex-criança soldado estão envolvidos, mais especificamente, dentro das áreas de Psicologia e da Saúde Mental. Contudo, existem outras concepções de resiliência sendo trabalhadas nos campos das ciências políticas e das Relações Internacionais que movimentam outras relações de sentidos e entendimentos. Sendo assim, elaborarei agora uma breve exposição da relação entre resiliência e RI com o intuito de mostrar, pontualmente, as variadas abordagens e espaços onde o conceito foi se acomodando nestes discursos.

Foi a partir da década de 1980 e 1990 que a discussão acerca da resiliência estacionou nas ciências políticas e nas RI. Pesquisadores dessas áreas começaram a trabalhar com a concepção da resiliência para entender desde as ações de grupos e indivíduos em meio a liberalização econômica e mudanças no serviço público até a influência de conflitos armados na vida dos indivíduos, preparação para riscos e infraestruturas de respostas. Desse modo, os debates e discussões sobre o tema se concentram na busca de uma forma de se estudar a resiliência e como se daria seu emprego no mundo político, sendo que, segundo Bourbeau (2015), isto se deve ao imaturo programa de pesquisa sobre os estudos de resiliência, à ideia errônea de que as RI inventaram um 'novo' conceito e à escassa pesquisa empírica dentro do campo. (p. 375). Seguindo o argumento do autor, são propostos cinco caminhos pelos quais a resiliência foi incorporada na disciplina de RI. (p. 377).

Primeiramente, a resiliência estaria ligada à perspectiva de governança global, sendo vista como persistência ou manutenção de uma ordem, norma social e instituição, assim, estudos sobre globalização, ruptura de soberania, liberalização econômica, etc. entram como exemplos. Em segundo, a resiliência também achou espaço no campo do desenvolvimento internacional, da ajuda humanitária e da redução de desastres, neste sentido, seu significado estaria mais próximo ao da 
Psicologia, em que o desequilíbrio é visto como negativo e a resiliência igual à positiva superação e adaptação. Várias organizações internacionais começaram a desenvolver programas sob a clave da resiliência, promovendo slogans sobre 'ser resiliente' como sinônimo positivo de flexibilidade e adaptação às dificuldades. (Bourbeau, 2015).

Terceiro, veio o modelo de controle de riscos influenciado pelos estudos sobre terrorismo e contraterrorismo, isto é, foram incentivados programas de preparação e treinamento para riscos e ataques, principalmente, no âmbito da comunidade. Portanto, a resiliência seria apresentada como uma estratégia relacionada com os discursos nacionais de segurança. Em quarto, alguns pesquisadores buscam entender a conexão entre resiliência e neoliberalismo através da capacidade de indivíduos em lidar com os desafios impostos pelo sistema ou da transferência de responsabilidade do Estado para o indivíduo ou da resiliência como negação e/ou aceitação do próprio neoliberalismo. (Bourbeau, 2015)

O quinto e último caminho apresenta a relação entre RI e resiliência de maneira mais ampla, ressaltando a necessidade de olhar além da instrumentalização do conceito, através de uma perspectiva que englobe um desenho mais abrangente da resiliência no mundo político. Bourbeau (2015) se coloca nesta quinta posição, destacando três proposições inter-relacionadas que orientam o estudo na área: 1) resiliência possui ambos os aspectos: negativos e positivos; 2) o conhecimento acerca da resiliência é contingente; 3) resiliência é um processo dinâmico, variado e sociocultural.

Neste sentido, esses discursos da resiliência, dentro dos campos das RI, em alguns sentidos, tangenciam e, igualmente, distanciam-se da análise da ex-criança soldado como resiliente; entretanto, as desenvolturas do termo no cenário político trazem outras formas de se projetarem as escritas da infância moderna e do conflito armado moderno dentro da gramática internacional. Movimentando noções de estabilidade, ordem, preparação, flexibilidade e adaptação, os significados plurais da resiliência nas RI refletem momentos e tempos de certas falas e de certos silêncios, de outras negações e permissões capazes de traduzir as posições temporais das ex-crianças soldado em relação à infância moderna e ao (pós-) conflito moderno. 


\section{4 \\ Histórias e estórias de (des)encontros: os difusos desenhos temporais da (ex-) criança soldado}

Meu avô era um grande contador de histórias, tinha um gosto abrangente para livros e documentários históricos, assim, além de minha avó, seus dois grandes amores eram as histórias e as estórias: as histórias e estórias que ele contava para seus netos e a História do mundo e do ser humano que ele lia e com as quais ele se deslumbrava nos livros e documentários. Eu amava o tom de sua voz enquanto narrava a mais simples e curta história, pois, ele encaixava os eventos em cada fala, ajeitando as referências próprias e alheias com aquele seu jeito único de sorrir para seus próprios pensamentos.

Tanto ao iniciar uma história como ao terminá-la, sua empolgação era sempre a mesma, ele ia mascando as palavras para frisar sua importância na frase, eram nesses momentos que eu entendia de onde minha mãe havia pegado o agudo das ênfases silábicas. O final não gostava de ficar ou criar raízes, meu avô ia adaptando as circunstâncias de acordo com nossas travessuras, às vezes, o mesmo enredo poderia ter vários desfechos diferentes. Ele fazia um papel de tradução para mim, suas histórias me faziam deixar um tempo e, em coincidente momento, permanecer em um mesmo tempo, entre meu mundo fantasioso e o 'real', entre a minha infância sua adultez; as nossas vidas ganhavam histórias e estórias; no momento em que eu o ouvia, era outro mundo que se erguia em mim. Era o sentimento de poder ser alguém outro mesmo sendo eu.

Quando meu avô contava uma história, portanto, era como se várias estórias surgissem em nós. E é com esta esperança que conto, aqui, mais outras histórias que não se demoram, tomam rumos outros, tornam passado em presente e se mesclam nas temporalidades. As (ex-) crianças soldado me mostraram muitas estórias ambíguas e plurais sobre seus envolvimentos militares e suas (des)contínuas relações com o (pós-) conflito. Por isso, busco refletir, neste trabalho, sobre estes meus encontros com as difusas imagens, falas e movimentos das (ex-) crianças soldado que me fizeram pensar e questionar as variadas disposições de nossa realidade social.

Assim, por entre as múltiplas temporalidades do envolvimento da criança no grupo armado e também no (pós-) conflito, pretendo mobilizar, em vários momentos, ao decorrer do texto, o recurso gráfico do parêntese no termo (ex-) 
criança soldado. O parêntese aqui tem uma proposição política, pois se mostra capaz de envolver certos conceitos e eventos alocados em uma disposição temporal linear e, ao mesmo tempo, bagunçar as temporalidades, trazendo eventos que estão e não estão no passado, no presente e no futuro. Além disso, o parêntese guarda e revela os contornos temporais nas (des)continuidades entre criança soldado e ex-criança soldado que vão além de uma concepção de ruptura com o passado militar, mobilizada no discurso do retorno (e também dentro dos discursos do trauma e da resiliência para sua categoria). Desse modo, o prefixo temporal 'ex' colocado entre parênteses busca traduzir os difusos desenhos temporais da categoria criança soldado e ex-criança soldado, através das relações confusas dos discursos do trauma e os da resiliência, (re)articulando a posição do ser e tornar-se a partir das possibilidades de 'misturas' e ambiguidades.

A roupagem do passado militar incorpora ao termo 'ex' seu entorno e contorno, o prefixo do que era permanece inscrito em seu significado e qualifica o que já não mais é no agora, orientando, igualmente, um futuro a ser esperado. Esta confusão de sentidos temporais, camuflada por entre o discurso do retorno, é o que busco frisar ao destacar a importância do parêntese na construção da categoria (ex-) criança soldado, que entra nos jogos temporais difusos através da dupla possibilidade de ser, ao mesmo tempo, criança soldado e ex-criança soldado em um mesmo tempo verbal. Frisando as (des)continuidades do (pós-) conflito entre passado, presente e futuro e questionando os eventos de rupturas temporais, o parêntese deixa visível o 'ex' silenciado pelas definições, alocações e flexões verbais de tempo que envolvem a categoria criança soldado.

Todavia, minha intenção não está em clarificar quando há diferenciação ou similaridade entre os conceitos da criança soldado e da ex-criança soldado, já que isto fixaria de novo uma verdade sobre a produção de suas categorias. Em contrapartida, pretendo realçar a ambiguidade, a confusão e a porosidade que se encontram nos discursos sobre o tema, mesmo que esses tendam a simplificar os dizeres para garantir um entendimento específico. Sendo assim, acredito que refletir sobre os discursos que produzem e reproduzem a (ex-) criança soldado como categoria se conecta ao modo com que as narrativas do trauma e da resiliência são direcionadas em suas histórias e experiências entre superação e esquecimentos, ajeitadas dentre uma relação temporal específica. 


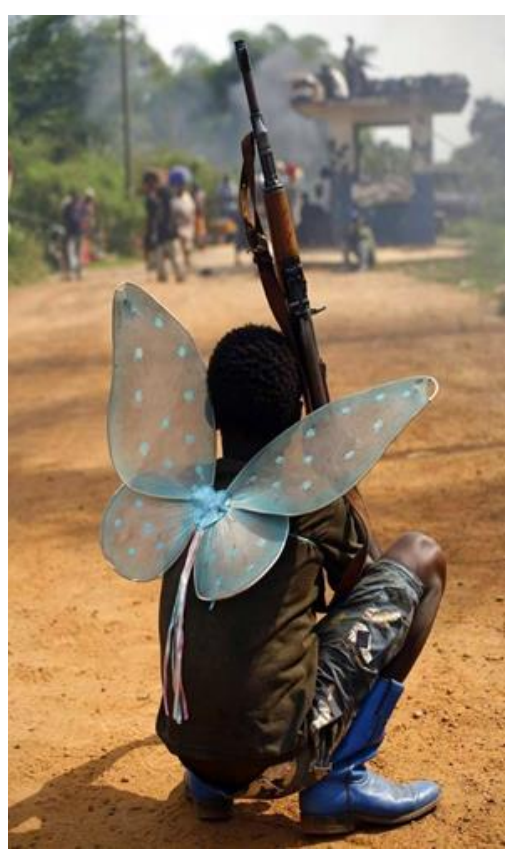

Figura 1: Imagem da produção do filme Johnny Mad Dog, 2008.

Encanto-me, particularmente, com esta imagem, que traduz sentimentos e dizeres difíceis de serem encaixados em letras, palavras ou atos de fala. Ela transpõe instrumentos e navegadores na imensidão artística das interpretações e nos choca a fronte através de inúmeras expressões. A arma, as botas azuis, as asas da borboleta, sua posição, tudo parece deixar um rastro no impessoal fictício da (ex-) criança soldado. A fantasia liberta a alma, eles dizem - "a imaginação nos faz voar" transforma os olhos para nos deixar sonhando, mesmo quando abertos. Durante as metamorfoses da vida, não existe apenas uma estrada, os passantes carregam armas mesmo desejosos de paz, de mudança.

Estes caminhos que abrem junto com os olhos refletem o que o passado foi e o que o passado é no agora, modificando a mirada para o futuro. Sob este enfoque, eu busco me questionar: qual seria a expressão ou o olhar desse menino? O que ele procura naquela estrada? Para mim, existe uma metamorfose se apresentando por entre as cores e os rumos, pois há uma transcrição lenta e contínua nos ares da possibilidade, da potencialidade do ser e tornar-se. Talvez ainda é podido ser a tal criança vulnerável neste vácuo descompassado. Porém, o que machuca mais: as asas ou a arma?

Os paradoxos que formam os fatos e a ficção, as estórias e histórias, o passado e futuro relacionam-se de variadas maneiras no espaço e tempo desta imagem, de uma fotografia que transparece o silêncio do movimento do ser (ex-) criança soldado brincando com concepções de imaturidade e inocência, juntamente com 
ideias de violências, desvios, passado e futuro. O acaso é uma possibilidade do nãodito, da condição de espera no presente, penso que é isto que nos rouba as falas nessa foto. Ela diz em silêncio como o processo de ser e tornar-se ocorre, muitas vezes, ao avesso e ao contrário, embaralhando as temporalidades e as possibilidades construídas para esta criança.

Talvez, a sua face esteja oculta porque ela não precisa dizer, as máscaras que carregam no termo criança soldado ou ex-criança soldado já nos levam a lugares comuns, cujo pensamento é orientado pelos vetores da narrativa da infância moderna e do conflito armado moderno junto a suas temporalidades. No discurso do retorno para a ex-criança soldado se acomodam expressões e lições para sua categoria, cuja formação oscila entre negações e permissões, passado e futuro, no conjunto das experiências que o (pós-) conflito desenrola.

Neste sentido, assim como Shapiro (2013), apoio-me na possibilidade de produzir um pensamento político-crítico ao reconhecer a filosofia (por entre as perspectivas das ciências sociais) como uma prática criativa e inovativa, capaz de construir conceitos e ideias. E, portanto, aberta também à articulação com as artes na promoção de um modo outro de se pensar e de se questionar a realidade social, tendo como base os encontros que nos fazem pensar. Ou seja,

when philosophy is conceived as conceptual invention, rather than as norms for truth testing and validation, it become hospitable to the epistemological contributions of those genres of the arts that challenge hierarchies of sense-making and entrenched models of intelligibility from which 'problems' tend to be unreflectively presumed. (Shapiro, 2013, p. 20).

Por conta disso, se de um lado as filosofias empiristas das ciências sociais se apoiam em questões sobre a validação e confiabilidade do conhecimento, por outro uma proposta filosófica crítica é capaz de envolver modelos estéticos de compreensão ao movimentar construções de conceitos e ideias em diferentes gêneros de expressão.

Neste momento, respaldo-me em uma referência de Shapiro (2013) sobre Rancière com o intuito de explicar o modo de compreensão a partir da "experiência estética" (p.9) capaz de perturbar as distribuições sociais autoritárias sobre identidade e, por isso, produzir um efeito político que problematiza os agrupamentos sociais e suas disposições. Além disso, inspirado em uma abordagem pós-Kantiana, Rancière e outros filósofos - como Deleuze, por exemplo - destacam 
como uma análise crítica vem com os encontros que desestabilizam as tradicionais condições do sensível ao suspenderem a coordenação comum das experiências.

Dessa forma, "what constitutes the aesthetics of knowledge from both Rancière and Deleuze's perspectives has to do with the way the encounter leads to an alteration in sensible experience" (Shapiro, 2013, p. 30). Tomando-se por base essa citação, vale ressaltar que Rancière elabora uma política do estético em que um trabalho artístico crítico constitui a política, sendo estética e política homólogas em si. Por isso, o encontro com os gêneros artísticos representa um momento de reflexão e questionamento passíveis de perturbar as disposições dominantes (sejam espaciais, temporais, etc.) do contexto em que estamos.

Sendo assim, aqui mostro um de meus encontros. Em 2012, tive meu primeiro encontro com o livro de Ishmael Beah, estava cursando o meu segundo ano de graduação em Relações Internacionais. Uma amiga me recomendou sua leitura após descobrir que eu iria fazer um trabalho acerca do comércio internacional de armas para uma disciplina e me sugeriu a possibilidade de investigar o 'fenômeno' da criança soldado em conexão. Fui à biblioteca da universidade, peguei o livro, meus olhos se fixaram na capa e a foto de um menino negro carregando uma arma enquanto caminhava - meio que despreocupado - calçando um chinelo amarelo despedaçado orbitou durante alguns segundos em meus pensamentos silenciosos. Naquele momento, fiquei sem saber se o folheava ali mesmo na frente das prateleiras da biblioteca e mantinha qualquer reação em sussurros ou se me permitia sentir qualquer coisa em qualquer altura na minha casa. Escolhi a segunda opção.

As primeiras páginas me despedaçaram, chorei por alguns minutos depois de ler as palavras de Beah sobre seu primeiro encontro com a guerra do país. Não avancei mais do que 50 páginas. Abandonei. Cheguei a renovar por alguns dias na biblioteca para tentar retomar a leitura. Falhei. Naquele ano, não consegui conhecer a história e trajetória de Ishmael Beah por inteiro, mas fiquei sabendo um pouco mais sobre a minha. Foi logo depois desta experiência que a categoria da criança soldado se fez presente em meus estudos; decidi, então, pesquisar este tema que tanto me intrigou.

Em 2016, tive meu segundo encontro com o livro, agora com outra capa e eu em outra rotina, li-o em partes, encaixando as leituras por entre meus períodos livres, consegui finalizá-lo. As impressões que tive, naquele momento, guiaram as minhas reflexões no agora sobre a categoria ex-criança soldado e seus desenhos 
temporais difusos por entre os discursos do trauma e da resiliência, discussões e reflexões que tento abordar neste trabalho.

Desse modo, as minhas reflexões aqui representam encontros que me fizeram pensar, interpretações que se manifestaram em minhas leituras e olhares ao artístico, cuja necessidade de expressão me trouxe à construção de reflexões e de dúvidas sobre a categoria (ex-) criança soldado e seus desenhos temporais difusos. Neste trabalho, trarei algumas fotos de (ex-) crianças soldado capazes de mobilizar focos e enfoques de crítica e questionamentos de sua categoria e também algumas cenas do filme Beasts of no Nation (2015), em que Agu - (ex-) menino soldado - é mobilizado, nas minhas análises, como sujeito estético.

Esses sujeitos estéticos, propostos por Shapiro (2013), são articulados por entre os gêneros artísticos e são capazes de movimentar questionamentos sobre o seu contexto social. Ou melhor, o interesse não está em decifrar os processos internos dos personagens que criam suas expressões e impressões da realidade (como dos sujeitos psicológicos), mas sim em como os seus movimentos no mundo e suas conexões nos traduzem, por meio de suas relações, inibições, proibições, etc., em que tipo de mundo nós vivemos.

O filme Beasts of no Nation (2015) mostra a relação de Agu com a guerra civil em seu país, um menino recrutado por um grupo armado não-estatal, que participa da guerra como soldado e, depois, faz parte dos programas de reintegração social destinados às ex-crianças soldado. Rearticulando e reinterpretando histórias e trajetórias de ex-crianças soldado, procuro mostrar e montar uma análise crítica sobre a produção de sua categoria trazendo a ambiguidade e a pluralidade que perpassam o seu entendimento temporal.

Portanto, neste momento, vejo a importância de me colocar na construção de minha escrita, no modo como articulo, por aqui, questionamentos e dúvidas sobre meus encontros e procuro pensar e refletir junto às minhas palavras. Os meus processos de escrita, assim, guiam-me na mostra de minhas dúvidas e perguntas pelos encontros de argumentação reflexiva, "because those encounters are ultimately articulated in how I write. " (Shapiro, 2013, p. 31).

Dessa maneira, percebo quão necessária se mostra esta abertura dos processos de escrita no campo de Relações Internacionais, pois “ the self-conscious presence of the writing subject contravenes the ususal fictive distance between reader and writer." (Inayatullah, 2011, p.7) e consegue complexificar as narrativas tradicionais 
neste campo de estudo ao desmantelar o objetivismo esperado na elaboração de uma pesquisa e/ou trabalho científico.

As linhas de minhas escritas e de meu posicionamento, neste momento, constroem-se na ambiguidade e multiplicidade do ser e do existir que reconfiguram e, simultaneamente, rompem as fronteiras que separam o pesquisador de sua pesquisa, os escritos objetivos dos emotivos, os fatos da ficção. Por isso, compreender as angústias, incômodos e surpresas do ser pesquisador não está isolado de nossas incertezas e desafios como ser humano no cotidiano, abrangendo o traduzível e o intraduzível de nossas experiências. O meu "eu" no texto, igualmente, busca refletir sobre o modo como venho acomodando os meus encontros com as histórias das (ex-) criança soldado e suas alocações temporais difusas e ambíguas. Além disso, creio que

the deeper secret we hide from ourselves is that, in the end, there is little to our claim of uniqueness or our presumed self-indulgence. Excavate the self and what do we find? Not ontologized and essentialized indulgence, but the differentiated dynamism of whole worlds. Scientists and mystics, I want to believe, can both harbor this claim. (Inayatullah, 2011, p. 8).

\section{5 \\ Disposição e conteúdo dos capítulos}

Em relação ao modo como construo aqui a minha análise, a disposição e o conteúdo dos capítulos seguem envolvendo todas essas linhas de reflexões e dúvidas sobre a categoria ex-criança soldado e sua alocação temporal. Em virtude disso, no segundo capítulo, meu objetivo está em explorar a formação e reprodução da categoria (ex-) criança soldado a partir de um discurso tradicional dominante ${ }^{11}$ que perpassa a construção da criança soldado como 'novo problema' global junto ao que chamei de discurso do retorno, que engloba os processos de reintegração social das agora ex-crianças soldado. Esses momentos interconectados no envolvimento da criança no grupo armado conseguem traduzir fins e recomeços ou rupturas e (des)continuidades temporais sobre uma concepção de infância ideal refletida na vulnerabilidade e inocência do ser criança - em conexão a uma concepção de conflito armado moderno como brutal e caótico.

\footnotetext{
${ }^{11}$ Este discurso tradicional sobre a concepção da categoria (ex-) criança soldado está embasado em um entendimento específico da infância moderna ocidental e sua relação com ao conflito moderno não-ocidental, levados a cabo por políticos, acadêmicos, grupos humanitários, entre outros.
} 
O discurso do retorno para as ex-crianças soldado é construído a partir de uma noção de ruptura com o passado militar que acompanha um certo ideal de volta à vida civil. Entretanto, os desenhos temporais difusos da categoria (ex-) criança soldado movimentam relações outras com o (pós-) conflito e suas (des)continuidades temporais, apresentando, igualmente, histórias que bagunçam as concepções esperadas de temporalidade e do envolvimento da criança no conflito.

No capítulo terceiro, busco analisar os discursos do tratamento do trauma e da resiliência em relação às ex-crianças soldado, frisando como uma concepção temporal é montada e reafirmada a fim de que certas memórias e planos pertençam e sejam ajeitadas, respectivamente, no passado do envolvimento militar e no futuro do sujeito resiliente. Nesse sentido, cabe a análise dos três documentos descritos acima que descrevem e reinscrevem a categoria ex-criança soldado e sua alocação temporal nos discursos sobre a resiliência (em constante relação com os do trauma) e sua relação com o passado militar traumático, visto que sendo tipos e estilos textuais diferentes, os textos me possibilitam refletir sobre as ambiguidades e incoerências na tentativa de estipular um significado para $a$ ex-criança soldado.

Seguindo as estórias e histórias das ex-crianças soldado em seus relatos, minha intenção no quarto capítulo se encontra em desdobrar a reflexão sobre a análise temporal envolvida nos desenhos temporais difusos da ex-criança soldado e sua posição particular de espera no presente: no aguardo e na esperança do ser (relações que movimentam superação e esquecimentos do passado militar). Sendo assim, trago as discussões presentes nos Estudos da Infância sobre o ser e o tornarse e as dinâmicas do adulto e da criança para a ex-criança soldado, buscando analisá-las além de binários opositores, mostrando as ambiguidades temporais da categoria. Neste ponto, pretendo abranger o conceito de espera para a ex-criança soldado com o intuito de abraçar as relações paradoxais entre os discursos do trauma e os da resiliência.

Durante os capítulos, vou me guiando pelo modo de análise de Shapiro (2013) na concepção do sujeito estético, uma vez que suas reflexões me proporcionam uma abertura para reinterpretar os desenhos temporais da ex-criança soldado, além de resgatar o aspecto emocional e subjetivo das temporalidades que se cruzam em nossos entendimentos e miradas ao (pós-) conflito. Portanto, apoiando-me na reflexão das imagens das (ex-) crianças soldado e em algumas cenas do filme Beast 
of no Nation (2015), conto mais um ponto das histórias e estórias ao permitir uma mistura entre meus escritos e os ambíguos desenhos temporais das ex-crianças soldado nas interpretações e percepções, principalmente, sobre as temporalidades e a subjetividade.

Finalmente, caminhar por essas estradas tão múltiplas e ambíguas desafia o conforto do saber moderno que anseia encaixar a escolha no isto ou no aquilo e eliminar as incertezas, mas que, na verdade, expressa rastros e traços da complexa e ambígua construção temporal do (pós-) conflito sobre, mormente, a (ex-) criança soldado e sua posição incômoda no momento presente.

Em suma, é como se o conflito ainda encontrasse um jeito de não relaxar, de permanecer e de continuar. Quando se é passado, não se tem espaço para descrever um alívio, há somente uma esperança vazia nos medos do amanhã. Os movimentos são pálidos como o luar na imensidão negra e o presente está ausente durante as metamorfoses da rotina. Neste encontro material, constroem-se confortos no 'olá', nos encontros e nas remanescências do que um dia era presença, olha-se no espelho e as sombras aparecem, o reflexo está presente, de repente, o passado é também presente e as cicatrizes se transformam em abertura, talvez para algo bom. 


\section{2 \\ Ser (ex-) criança soldado: desvios e possibilidades}

\section{1 Introdução}

Nas palavras ritmadas de Emmanuel Jal, suas histórias vão sendo cantadas: "All my life I've been hiding in the jungle. The pain I am cutting is too much to handle. Who's there please to light up my candle? Who's there anyone to hear my cry? Here I am, pale and dry, no one to lead us, I wonder why?" (Jal, 2008). Sua voz no compasso de hip-hop constrói uma narrativa estética presente sobre um passado das experiências que conjugam seu viver entre o passado militar e o sujeito adulto. Entre tons passivos e ativos, entre presente e passado, as concepções do ser criança e do ser adulto e também do trauma e da resiliência vão sendo desenhadas e reproduzidas por entre certas histórias e certos sujeitos. Assim, na presença destes caminhos, os tempos e temporalidades são, igualmente, desenhados na produção das memórias e dos planos para a (ex-) criança soldado entre o passado militar negativo e o futuro do adulto estável. Desse modo, percebo que as histórias contadas e fixadas para as ex-crianças soldado no presente vão se ajeitando em tons e termos passivos e reafirmando um entendimento específico sobre a formação da sua categoria e o envolvimento militar infantil.

Neste capítulo, proponho, portanto, apresentar, principalmente, como a (ex-) criança soldado ganha sentido como categoria por entre os discursos que a formam como 'novo fenômeno' junto com os processos de reintegração social (no que chamei, de maneira mais abrangente, de discurso do retorno). Estes discursos são capazes de conduzir a um imaginário do ser ex-criança soldado e de sua alocação temporal dentre a (re)produção das narrativas da infância moderna e do tempo linear, traduzindo os desvios e as possibilidades projetados para sua categoria. Ou seja, esses desvios e possibilidades passam pela (re)produção da categoria (ex-) criança soldado como 'nova crise' global - tão presentes nas narrativas humanitárias e de segurança internacional - e também pela atuação dos programas de reintegração social para a agora ex-criança soldado em necessidade de tratamento e intervenção.

A categoria ex-criança soldado, nestas linguagens, representa um desvio em busca da normalidade, movimentando o passado em relação à criança soldado e o 
presente no ser criança - indivíduo menor de dezoito anos de idade ${ }^{12}$ - junto aos processos de tornar-se um adulto no futuro. No entanto, as múltiplas temporalidades que coexistem nos enredos das ex-crianças soldado expõem as (des)continuidades de se pensar a infância moderna (ocidentalizada) em relação ao (pós-) conflito moderno (não-ocidental). Sendo minha ideia aqui recuperar e, ao mesmo tempo, questionar a posição do prefixo 'ex', que apoia uma visão de infância no singular e uma temporalidade específica, e o quanto ele carrega concepções de ruptura entre a normalidade e o desvio.

Sendo assim, o que vem a significar o 'ex'? Nas ideias que movimentam as palavras e suas junções, entendo que o ser ex-criança soldado se encontra na potencialidade de alocar o ser criança passivo no presente ao deixar a criança soldado no passado e, simultaneamente, o adulto no futuro; refletindo as dúvidas, ambiguidades e incoerências de se pensar a infância moderna pela vida adulta moderna, o passado pelo presente e o trauma pela resiliência. Desse modo, o 'ex', bem entendido como prefixo temporal, também consegue trazer a formação do sujeito que existe entre a categoria. Sendo que os desvios e as possibilidades pensados, neste contexto, traduzem o que é esperado para a ex-criança soldado e qual subjetividade caber-lhe-ia melhor. Tal categoria, portanto, é colocada em espera, borbulhando a ansiedade para a estabilidade do sujeito racional; com um passado conturbado pela violência dentro do grupo armado, o tempo presente é uma constante incógnita orientada para o futuro: será um adulto saudável e bemsucedido ou não?

Porém, de outro lado, este 'ex', de acordo com os discursos tradicionais, deve ser capaz de mostrar mais respostas do que perguntas. As falas que guiam tais preocupações, entre esses discursos, deslizam entre as ameaças, inseguranças e, ao mesmo tempo, a notável maleabilidade constituinte do entendimento da (ex-) criança soldado. Ou seja, os apelos tomam a forma universal de intervir: "our collective task as an international community is to promote children's capacity for resilience by minimizing risks and maximizing opportunities." (Magid; Boothby, 2013, p.47).

Assim, penso, por um lado que a condição desviante da (ex-) criança soldado se apresenta em relação a duas narrativas: primeiro, a da infância moderna ideal da

\footnotetext{
${ }^{12}$ De acordo com a CDC de 1989 em seu primeiro artigo.
} 
criança, essencialmente, inocente e segunda, a da sua posição incerta e duvidosa no presente. Esses fatores correspondem aos riscos a serem minimizados na tentativa de bloquear as dúvidas e paradoxos que cercam o próprio significado da categoria ex-criança soldado e de suas relações com o (pós-) conflito.

As suas possibilidades vão se desenrolando por meio de uma ideia de retorno à infância desejada pelo discurso de vítima e dos espaços e tempos dispostos às excrianças soldado, narrando suas vivências entre superação e esquecimentos, cujas linhas parecem fazer sentido na conquista do ser resiliente perante seus traumas. As possibilidades de entendimento da categoria da ex-criança soldado, portanto, estão na capacidade do discurso predominante do trauma e da resiliência em estabelecer um significado comum à categoria pelas divisões temporais do passado militar e o futuro resiliente. Consequentemente, maximizar as oportunidades representa alinhar as experiências das ex-crianças soldado no tempo e ser capaz de detectar os eventos de rupturas, reconfigurando e/ou minimizando a ocorrência do trauma por meio da resiliência, eventos esses aliados a uma concepção de retorno à infância idealizada.

Levando-se em conta o exposto, o caminho que pretendo traçar neste capítulo passa, primeiramente, pela (re)produção da criança soldado como categoria, juntamente com sua construção como 'crise' no contemporâneo ao discurso do retorno à vida civil para a então ex-criança soldado e seus ideais de superação. Posteriormente, busco trazer uma análise mais crítica sobre construção da infância temporal e como a (ex-) criança soldado veio a ser entendida a partir de desvios e possibilidades da narrativa da infância moderna ocidentalizada em relação ao (pós-) conflito moderno não-ocidental e de sua alocação temporal. Por último, a partir da desconstrução das imagens destinadas às (ex-) crianças oldado - vítimas, monstros e heróis redimidos - (Denov, 2010) e da apresentação de outras histórias e estórias sobre as múltiplas relações da criança com o (pós-) conflito, tornar-se-á possível bagunçar as falas e reconhecer as ambiguidades temporais que cercam a produção da categoria ex-criança soldado.

Finalmente, na conclusão, procuro retomar as reflexões sobre desvios e as possibilidades pensados para a ex-criança soldado por entre o discurso do retorno (que também engloba, de certa forma, os discursos do trauma e da resiliência que a produz como categoria), puxando a discussão para a sua alocação temporal entre o passado militar negativo e o futuro adulto da resiliência e como se dá o 
relacionamento entre estes "entres" do tempo - ponto que será aprofundado no terceiro capítulo.

\section{2}

\section{A categoria (ex-) criança soldado: o ser em suspensão}

Primeiramente, considero ser possível encarar o conceito da criança soldado, por assim dizer, como uma " unnatural conflation of two contradictory and incompatible terms. " (Rosen, 2005, p.3), paradoxal nos sentidos que movimentam dois polos extremos de entendimento. Por um lado, o termo criança parece refletir em nossas mentes qualidades como ingenuidade, imaturidade, incapacidade de se autogovernar, entre outros fatores que modelam uma imagem de vulnerabilidade $\mathrm{e}$ inocência dada como 'natural' ao período da infância. De outro lado, a imagem construída do ser soldado incorpora entendimentos que orbitam na figura masculinizada do sujeito adulto atuante na guerra com expertise de administrar e efetuar uma organizada violência, sendo que a base por trás da condição de existência de um grupo armado se acomoda no treinamento, preparação e operação desses agentes. São nestes dois mundos tidos como distintos - um situado na paz e inocência da criança e o outro na violência do contexto de guerra do mundo adulto - em que a formação discursiva de específicos sentidos e concepções se apoia, vindo uma sensação de estranheza e desconforto quando colocados juntos.

Nesta minha análise, desse modo, a categoria criança soldado estará sempre posta em dinamismo e questionamentos, ou seja, ao invés de tratá-la como um termo naturalizado e passivo entre os discursos tradicionais que a formam principalmente, aqueles que a traduzem como 'crise' no contemporâneo - pretendo aqui reconhecer como sua (re)produção social como conceito e categoria é capaz de movimentar determinados entendimentos sobre o lugar e tempo da infância moderna, da guerra moderna e do modo como estes dois mundos se relacionam (sobretudo quando encaixados no discurso do retorno para a agora ex-criança soldado).

Dessa maneira, assim como Ben-Ari (2011), percebo que a situação de incompatibilidade entre a "criança" e o "soldado" se mostra intensificada a partir da difusão das imagens das crianças soldado por meio do que o autor chama de uma “frouxa coalização" (p.3) formada pela mídia, políticos, tomadores de decisões, 
pesquisadores (sobretudo, no campo da Psicologia), atores de segurança, defensores dos direitos humanos e ativistas humanitários. Esta coalizão encara a posição da criança na guerra como insegura e em necessidade de salvamento, sendo a (ex-) criança soldado "the very personification to hazard posed by armed conflict and social disorder" (Ben-Ari, 2011, p.3).

Assim como mostrarei no próximo capítulo com o discurso da resiliência e do trauma para a ex-criança soldado, a sua categoria como objeto de pesquisa é, igualmente, dominada pelos campos da Medicina, Psiquiatria, Psicologia e Biomedicina, ressaltando o impacto, essencialmente, negativo da presença da criança na guerra. (Ben-Ari, 2011 apud Boyden; De Berry, 2004). A criança soldado é projetada por esta 'frouxa coalizão' como, basicamente, vítima do conflito e corrompida pelo sujeito adulto a cometer atos violentos, pois sua posição como, primeiramente, criança faz com que qualquer link com a violência se torne desconfortável em termos morais.

É neste sentido que, segundo Tabak (2015), o discurso predominante da criança como, essencialmente, inocente e vulnerável produz a criança-soldado ${ }^{13}$ como novo 'problema' do internacional em necessidade de salvamento e proteção por meio de dois fatores inter-relacionados: 1) as (ex-) crianças soldado têm problemas que devem ser resolvidos pela intervenção do internacional; 2) as crianças soldado são encaradas como um problema social ao se desviarem do campo semântico e conceitual reconhecido da infância moderna. (2015, p.34). Pretendo me aproximar desta discussão neste capítulo, apontando os desvios e as possibilidades projetados para a categoria ex-criança soldado na produção binária do ser criança/ser adulto, do conflito/paz, criança soldado/ex-criança soldado, do público/privado nos discursos tradicionais sobre o tema, principalmente, aqueles propagados por essa "frouxa coalizão" adulta que emaranham os dizeres e os entendimentos sobre quem é a criança soldado e, já por consequência, quem é a excriança soldado.

\footnotetext{
13 Tabak traz o hífen entre a criança e soldado como uma marca gráfica capaz de desafiar e, ao mesmo tempo, (re)produzir duas categorias da sociedade moderna: o conflito como espaço violento e inapropriado para a criança e a criança 'normal' como inocente que deve ser protegida e retirada da guerra. $(2015$, p. 54).
} 


\subsection{1}

\section{Quem é a (ex-) criança soldado para o internacional?}

Em 2003, a organização Human Rights Watch publicou um relatório intitulado Forgotten fighters: child soldiers in Angola sobre a situação das (ex-) crianças soldado em Angola no contexto de pós-conflito, no qual trata sobre as dificuldades impostas à reintegração social das ex-crianças soldado no país. Após narrar, brevemente, sua experiência no grupo armado FAA (em três parágrafos curtos), o ex-menino soldado Felipe A., de dezessete anos, é descrito como "wearing tattered clothing and visibly underweight, he was nervous and shaking throughout the interview. " (Human Rights Watch, 2003, p. 14). Esta imagem da ex- criança soldado além da arma, como indivíduo digno de pena, viria como forma de apelo à comunidade internacional, frisando a necessidade de ajuda e salvamento dessas crianças que deixaram as armas para trás e agora, aterrorizadas e traumatizadas, mal têm o que vestir e/ou o que comer.

A partir desta condição de vítima que demanda compaixão, a ex-criança soldado é movimentada em voz passiva nestes discursos humanitários como, 'automaticamente' traumatizada em urgente necessidade de apoio e suporte adulto alheio. Não pretendo desqualificar a veracidade da descrição deste ex-menino soldado, mas sim ressaltar que a produção desta exposição e o porquê de sua existência no texto estão relacionados com uma certa visão de como a ex-criança soldado é construída nos discursos internacionais (articulados pela 'frouxa coalizão') e o modo com que sua categoria entra em cena, estando, de certa forma, em consonância a uma narrativa de retorno a uma infância ideal e do tempo do conflito já no passado.

Por mais que no título do relatório esteja escrito criança soldado, o seu conteúdo conjuga as histórias sobre o envolvimento militar da criança no passado, sendo, por isso, mais bem entendidas temporalmente com base nos entornos explicativos do prefixo 'ex'. As confusões, silêncios e ambiguidades que cercam a relação de sentidos entre a criança soldado e a ex-criança soldado tentam ser traduzidos, nestas minhas palavras, pelos recursos gráficos do parêntese no termo (ex-) crianças soldado, capazes de mostrar os desenhos temporais difusos e 
(des)contínuos que categorizam a ex-criança soldado em relação às temporalidades plurais do (pós-) conflito.

Além disso, vejo que as ONGs, tais como a Human Rights Watch, Save the Children e Child Soldiers International (antigamente, Coalition to Stop the Use of Child Soldiers) lideram campanhas contra o recrutamento infantil e têm um papel importante na promoção do entendimento da categoria (ex-) criança soldado na gramática do internacional. Noto, contudo, que a maioria dos relatórios sobre (ex-) criança soldado a localizam dentro do continente africano, ou seja, "seven out of nine reports put out by Human Rights Watch on the use of child soldiers in the last ten years (1996-2006) concern sub-Saharan Africa countries.” (Jézéquel, 2006, p.3).

A partir do supracitado, ao trazer a produção da categoria da (ex-) criança soldado e sua alocação temporal para análise, percebo o quanto a construção de um ideal de infância articulado pelo mundo ocidental, de certa forma, é transportado para, principalmente, os países africanos em conflito no intuito de justificar as intervenções humanitárias em nome do 'salvamento' das crianças (a partir de um ideal específico de infância e de seu tempo). Endossando este posicionamento, "it must be understood that children constitute a central issue in efforts to legitimise Western interventions in Africa." (Jézéquel, 2006, p. 4). Por conta disso, o pensamento comum da criança soldado como caos e desordem social no presente parece fixar, igualmente, um lugar comum para sua ocorrência, rearranjando uma noção de 'problema' colocado no Outro geograficamente e temporalmente distante.

Esta discussão abrange muitas outras relações na projeção do 'outro' como inferior, relações de identidade e diferença que emanam nos discursos pós-coloniais e que acham espaços também na produção da categoria (ex-) criança soldado. Reconhecendo a pluralidade e heterogeneidade do conceito e do entendimento do ser (ex-) criança soldado, penso que a análise das relações entre os dois mundos o da infância moderna (ocidentalizada) e o da guerra moderna (não-ocidental) e suas temporalidades - está sendo constantemente modelada pelos discursos que categorizam a (ex-) criança soldado. Parafraseando: percebo que a construção das bases de entendimentos do ser criança e do ser soldado, que orbitam entre o mundo infantil e adulto e também entre passado e futuro, vão se relacionando de modo ambíguo ao buscarem fixar cada vez mais uma distância entre eles. 
Já em relação aos números, mesmo com dificuldades em se estabelecer uma cifra segura da quantidade das crianças soldado, estima-se que dentre ao menos 86 países haja cerca de 300.000 crianças recrutadas (Coalition to Stop the Use of Child Soldiers, 2008, p. 12). O dígito dos 300.000 é reproduzido em quase todos os relatórios e documentos sobre a temática das (ex-) crianças soldado é um número quase natural quando se fala sobre o recrutamento infantil, sendo responsável por consolidar a base numérica, mesmo que incerta, para o discurso da formação da categoria da criança soldado e de sua numeração diante do conflito moderno.

Uma primeira referência legal à concepção da criança combatente apareceu dentro dos discursos humanitários e políticos internacionais a partir de 1977 com a introdução dos protocolos adicionas na Convenção de Genebra (1949) (Jézéquel, 2006). Em 1989, a Convenção dos Direitos da Criança, mantendo a mesma linguagem que o documento anterior, abordou a temática do recrutamento infantil a partir de uma concepção de infância (ocidentalizada) e de sua confusa relação com a guerra - pensada ainda, basicamente, nas bases do conflito armado tradicional. ${ }^{14}$

No artigo 38, parágrafo $3^{\circ}$ da CDC, está disposto que os Estados partes devem evitar o recrutamento militar de qualquer indivíduo menor de quinze anos de idade e, caso haja a possibilidade de escolha, dar preferência aos mais velhos - acima de quinze anos. Sendo assim, a definição etária da criança (indivíduo menor de dezoito anos) presente na própria Convenção e sua idade mínima para o recrutamento se encontram ainda em descompasso, o que, em um primeiro momento, revela uma confusão acerca de qual é a relação desejada entre esta tal infância etária e a participação no conflito (algo que tentará ser remediado com o Protocolo Opcional, explicado mais adiante). Além disso, o meio de se construir a participação das crianças na guerra se mantinha amarrado na percepção de que o Estado soberano é o único capaz de fazer guerra e, igualmente, de recrutar essas crianças.

Percebo, neste sentido, que a definição e construção da (ex-) criança soldado como categoria vem sendo (re)produzida pela gramática do internacional por entre

\footnotetext{
14 Trago aqui a explicação da tipologia clássica da guerra de acordo com o trabalho de Clausewitz, que entende a guerra como uma luta em escala ampliada, um ato de violência que tenta obrigar um dos lados a submeter à vontade do oponente. Desse modo, as guerras se dão entre as forças armadas de Estados diferentes e por motivos político, ou seja, seu objetivo é político, porém seu meio é militar. Portanto, a guerra tem uma condição tripartite para sua existência: meios violentos, objetivos militares e fins políticos.
} 
a mobilização dos discursos da agenda humanitária, da lei internacional e de segurança internacional através de, principalmente, seis documentos importantes, juntamente com as resoluções emitidas pelo CS das Nações Unidas desde 1999 até atualmente, cuja atenção se encontra na proibição do recrutamento infantil e do uso de criança em conflitos armados. Esses documentos tentam estipular um entendimento para a categoria da (ex-) criança soldado a partir da produção de um distanciamento entre os discursos da infância moderna e daqueles conduzidos para os conflitos modernos.

O primeiro texto, portanto, é o Relatório Machel de 1996, nomeado “Impacto dos Conflitos Armados nas Crianças” e elaborado por Graça Machel, ex-ministra da Educação em Moçambique a pedidos do ex-Secretário-Geral das Nações Unidas, Boutros Boutros Ghali. Este documento tomou forma por conta da Resolução emitida pela Assembleia Geral de 1993 referente à atuação das crianças em conflitos armados. Esta pesquisa foi conduzida por uma série de vinte e quatro estudos de caso sobre o uso de crianças soldado por meio da análise dos conflitos armados nos últimos trinta anos (Machel, 1996, p. 16). Incluiu em seu cerne concretas recomendações para a proteção das crianças em conflitos, frisando a urgência de se acabar com esta forma de exploração infantil. (Tabak, 2015,).

Machel (1996, p. 16) enfatiza que "one of the most alarming trends in armed conflict is the participation of children as soldiers". Neste sentido, segundo Tabak (2015), este documento arranjou as bases principais de entendimento que constitui o discurso 'da' criança soldado, promovendo 'a' concepção da "criança natural" que não pode combater, universalizando assim suas necessidades, sejam biológicas ou sociais, endossando o posicionamento de Machel (1996), para quem "the needs of all children are the same: nutritious food, adequate health care, a decent education, shelter and a secure and loving family" (p. 10).

Ademais, no texto do relatório, o entendimento do conflito moderno é produzido como 'diferente' do tradicional, mais brutalizado e desorganizado, localizando-se no interior de alguns Estados pós-coloniais, onde a violência armada também é praticada por outros grupos além do Estado. Neste sentido, "the patterns and characteristics of contemporary armed conflicts, however, have increased the risks for children." (Machel, 1996, p. 13). Discursos como estes produzem um determinado entendimento para a (ex-) criança soldado (projetada, no contexto contemporâneo, como 'problema') com base na difícil relação construída cada vez 
mais como de extremos antagonismos entre os dois mundos: o da infância moderna ocidental (com a criança, essencialmente, inocente, vítima e vulnerável) e o do conflito contemporâneo não-ocidental (projetado como bárbaro, brutal e irracional).

Por isso, ao tratar das especificidades desta criança moderna, no singular, como não compatíveis com as atividades do conflito armado moderno, também no singular, os discursos que traduzem a categoria (ex-) criança soldado se tornam cada vez mais díspares e indecisos, demandam escolhas e caminhos difíceis de permanecerem. Por consequência, a posição da criança soldado no presente é configurada como 'crise' ou 'problema' no internacional, em necessidade de urgente intervenção a fim de retirar o mundo negativo do conflito moderno de sua tradução no presente.

Logo depois, os Princípios da Cidade do Cabo de 1997 vieram como outro documento capaz de nortear a concepção da categoria (ex-) criança soldado e que tinha como objetivo desenvolver estratégicas com a finalidade de prevenir o recrutamento de menores de dezoito anos de idade por grupos armados (estatais e não-estatais) e também de dar atenção aos processos de reintegração das ex-crianças soldado na sociedade. Adotado em um Simpósio organizado pela UNICEF no continente africano, o texto traz, em destaque, a relação entre a categoria (ex-) criança soldado e o discurso da infância moderna ao tentar promover uma definição internacionalmente aceita para o conceito, abrangendo a relação etária do ser criança e o significado além do soldado. Sendo assim, a partir deste documento, o termo criança soldado foi trazido para além da criança que combate, ou seja,

[...] child soldier in this document is any person under 18 years of age who is part of any kind of regular or irregular armed force or armed group in any capacity, including but not limited to cooks, porters, messengers and anyone accompanying such groups, other than family members. The definition includes girls recruited for sexual purposes and for forced marriage. It does not, therefore, only refer to a child who is carrying or has carried arms. (UNICEF, 1997, p. 12).

"Vazado" o entendimento do termo soldado - relacionado ao conflito moderno (não-ocidental) -, a criança soldado como categoria se mostra plural entre suas funções no grupo armado, mostrando que a relação de incompatibilidade com o conflito moderno está além da utilização ou não de uma arma, mas sim em seu próprio envolvimento militar no presente. 
Junto a isso, o terceiro documento, Estatuto de Roma do Tribunal Penal Internacional da CPI, adotado em 1998 e entrando em vigor em 2002, em seu artigo $8^{\circ}$, penaliza crimes de guerra, mais precisamente, classifica como crime de guerra o recrutamento de menores de quinze anos nas forças armadas governamentais e na participação de hostilidades. (Artigo 8 (2) (b) (xxvi)).

Além disso, em quarto, a Convenção $n^{\circ} 182$ da OIT, que foi aprovada em 1999 entrando em vigor em 2000, incluiu o recrutamento militar forçado e o envolvimento de menores de dezoito anos em conflitos como a pior forma de trabalho infantil. Neste documento, destaco a construção do recrutamento militar infantil como um tipo de trabalho (conceito pertencente à esfera adulta), trazendo junto concepções de exploração e utilização das crianças para funções não cabíveis à sua categoria social de dependência ao ser adulto.

Estes dois documentos em formato de leis internacionais posicionaram o 'problema' da criança soldado como pertencente, essencialmente, ao mundo adulto. Ou seja, a responsabilização do recrutamento infantil - já projetado como incompatível - é colocada na parte adulta capaz de recebê-la, pois a criança inocente e irracional (no discurso da infância moderna) se mostra incapaz de atuar no conflito por sua vontade e/ou necessidade e, igualmente, de optar por si só sobre seu recrutamento militar.

O Protocolo Facultativo da Convenção dos direitos da Criança (OPAC, sigla em inglês) foi aprovado na Assembleia Geral das Nações Unidas em 2000 e entrou em vigor em 2002. Esse protocolo pretendia, basicamente, elevar a idade mínima do recrutamento obrigatório pelas forças armadas e da participação nas hostilidades de quinze para dezoito anos, estipulando também que, caso haja recrutamento voluntário com idade inferior, deverá ser a partir dos dezesseis anos, e o Estado deverá oferecer uma série de salvaguardas e garantias, como a autorização formal dos responsáveis pela criança. Ademais, nenhum grupo armado não-estatal, isto é, fora das forças armadas, pode, em momento algum, recrutar menores de dezoito anos.

Tal documento representou o esforço humanitário para levantar o marco etário até os dezoito anos em relação ao recrutamento infantil, rearticulando a participação da criança em conflitos armados ao inserir a definição etária de infância - presente na Convenção dos Direitos da Criança - para os documentos do recrutamento infantil. Outrossim, este Protocolo permite que Estados soberanos 
recrutem crianças entre dezesseis e dezoito anos como voluntárias - com a autorização dos responsáveis -, contudo impede que qualquer grupo armado nãoestatal faça o mesmo, sendo que, conforme Rosen (2005), este fato traduz os primeiros passos do corpo internacional em criminalizar a rebelião e a revolução. Ressaltando também a primazia do Estado em relação ao domínio do espaço da guerra e à autoridade de interferência no ser criança e de sua relação temporal com a violência.

Por último, os Princípios de Paris de 2007 foram o resultado de uma revisão e atualização dos Princípios da Cidade do Cabo, em que o termo criança soldado passa a ser substituído e utilizado pela UNICEF por criança associada a uma força armada ou grupo armado. A possibilidade aqui de articular um novo conceito, ao meu olhar, tem a ver com uma mudança de linguagem passível de traduzir este novo fenômeno e a relação entre a infância moderna e a guerra moderna, indo além da maior coerência de seu significado - não somente a criança que combate. Ou seja, a saída do conceito de 'soldado' e de seu entendimento, basicamente, relacionado à uma atuação do mundo adulto realocou, de certa maneira, uma linguagem mais 'cabível' ao sentido infantil de incapacidade e passividade. A criança adjetivada como associada a uma força armada ou a um grupo armado se encontra mais bem inserida nos discursos que a qualifica como vítima do conflito do que quando qualificada como 'soldado'.

Acrescenta-se, ainda, que a presença dos dois termos separados: grupos armados e forças armadas movimenta uma posição de autoridade do Estado no tange à decisão e emancipação das crianças e à possibilidade de alocar a violência na infância, caso o veja como necessário aos seus interesses. Falar em grupos armados já corresponde em alocar a violência armada fora do Estado e, desse modo, como "fora de controle". A presença da criança nessas frentes transparece o medo e a incerteza promovida por estas novas guerras (bárbaras), mesclados com a urgente necessidade de " ter que fazer algo sobre isto".

A child associated with an armed force or armed group refers to any person below 18 years of age who is or who has been recruited or used by an armed force or armed group in any capacity, including but not limited to children, boys and girls, used as fighters, cooks, porters, messengers, spies or for sexual purposes. It does not only refer to a child who is taking or has taken a direct part in hostilities. (UNICEF, 2007, p.7). 
Em razão disso, considero que a categorização da criança soldado passa, conjuntamente, pela sua produção como novo problema global inserido na agenda de segurança internacional e nos discursos humanitários - discursos dominantes no campo das Relações Internacionais - e traduzido pela 'frouxa coalizão'. Assim, sendo projetada entre as práticas dos novos conflitos (não-ocidentais) que estruturam as relações sociais e o espaço da violência, a categoria (ex-) criança soldado como 'crise' é mobilizada e ressignificada dentre uma específica ideia de infância (ocidentalizada) por meio de exclusões e impossibilidades. Mesmo que, em tempos passados, muitas crianças frequentassem os campos de batalha durante, por exemplo, a Segunda Guerra Mundial. (Rosen, 2005).

Assim, "broadening the protections for children, including redefining and expanding the definition of childhood, adds to the growing list of internationally recognized legal obstacles to war." (Rosen, 2005, p. 136). E aqui acrescento uma específica ideia de infância e uma singular noção de guerra: a guerra do mundo nãoocidental. Há, portanto, uma relação indissociável entre a produção do banimento do recrutamento infantil e as tentativas morais e legais para dificultar tal conflito armado, sendo que a ideia das (ex-) crianças soldado como 'nova crise' apresentase como uma crise política moderna. (Rosen, 2005).

Concernente a essa fala, entendo que a produção desta crise política moderna se encontra na relação construída nas relações, cada vez mais, de incompatibilidade e antagonismos entre o discurso da infância moderna e o discurso do conflito armado moderno. Vendo o mundo da infância moderna como positivo e desejável, a realidade do conflito moderno (não-ocidental) e de suas temporalidades é articulada como negativa e incabível para a participação da tal criança inocente e vulnerável.

Além desses aspectos mencionados, as temporalidades que marcam a categoria ex- criança soldado se apresentam como (des)contínuas e ambíguas, assim como o embate de sentido desses dois mundos, pois, a relação entre a durabilidade do conflito moderno e o da infância temporal moderna articula paradoxais posições do ser (ex-) criança soldado no tempo. Enquanto o prefixo 'ex' movimenta noções de passado para o militar, para o discurso da infância moderna, este, igualmente, projeta concepções de estabilidade para o futuro adulto, ainda que o conflito armado continue acontecendo no contexto social ou nas relações estabelecidas pelas crianças. As minhas reflexões, portanto, envolvem esses desenhos temporais 
ambíguos e múltiplos das (ex-) crianças soldado que desafiam o entendimento linear do tempo moderno e da infância temporal.

Destarte, neste trabalho, como já dito, prefiro seguir com o conceito de (ex-) criança soldado com vistas a transparecer o incômodo encontro entre os dois mundos conflitantes e da alocação difusa da ex-criança soldado na temporalidade moderna. O desconforto, impacto e (des)continuidades que as palavras 'ex', 'criança' e 'soldado' trazem quando juntas conseguem mostrar como certas ideias e discursos são mobilizados e por que determinadas práticas são naturalizadas dentro dos anseios do internacional, traduzindo sua categoria como um 'problema' em si. Por isso, vejo a importância em me debruçar nas entranhas deste conceito ao reparar como ele veio a desempenhar uma função nominativa e explicativa em um momento e, posteriormente, saiu pelas portas dos fundos e foi substituído por outro termo dito mais 'apropriado' a uma realidade infantil ideal em oposição ao 'caos' do conflito armado moderno. Esse fato se explica porque são nesses espaços onde as vozes e os silêncios se misturam na projeção de determinados desvios e possibilidades para a categoria (ex-) criança soldado e sua confusa e plural alocação temporal.

\subsection{2 \\ (Ex-) criança soldado como 'novo problema' global}

Em 2012, a Iniciativa Roméo Dallaire sobre Criança Soldado lançou a primeira edição do texto Child Soldiers: a handbook for security sector actors, com o objetivo de reforçar as variadas funções dos agentes de segurança - militares, polícia e peacekeepers - em relação à proteção das crianças afetadas pela guerra. Este manual de treinamento visa conscientizar os agentes de segurança sobre o 'problema' das crianças soldado e promover um guia operacional básico para a ação no momento do contato entre os sujeitos adultos de segurança e as crianças soldado (2012). A ideia é que, se os agentes de segurança não forem propriamente treinados para lidarem com o fenômeno das crianças soldado no campo de batalha, eles agirão de maneira emocional e colocarão em risco tanto a vida de seus companheiros quanto a própria operação. Além do mais, eles podem desenvolver efeitos psicológicos negativos como o estresse pós-traumático, por exemplo, ao se chocarem com a criança soldado atuando no conflito. Por essa razão, 
All security sector actors must acknowledge the unique duality of the child soldiers. On the one hand, he or she is still very much a child - someone who is vulnerable, impressionable, frequently irrational and worthy of protection. On the other, he or she is a soldier - and to deny this fact may be both detrimental to the safety of the security sector actors and not in keeping with the child's own experience. (Roméo Dallaire Child Soldiers Initiative, 2012, p.47).

O enfrentamento no presente com as criança soldado é traduzido, nessa linguagem, como um "dilema moral” (Roméo Dallaire Child Soldiers Initiative, 2012, p.47) para os agentes de segurança, como colocado no texto, capaz de acentuar e expressar a distância entre as duas narrativas modernas ou os dois regimes de verdades ${ }^{15}$ : a criança e o soldado e o quão, na prática da segurança, eles se mostram como incompatíveis juntos, já que “the security sector actor's two moral imperatives are: 1) to protect innocents; and 2) to defeat the enemy." (Roméo Dallaire Child Soldiers Initiative, 2012, p.48). Tendo como base esse quadro, a preparação que este manual promete vem na tentativa de evitar tal dilema moral, ou melhor, reajustar estas duas missões - que a criança soldado, em sua dupla condição, consegue bagunçar tão bem - apresentando aos agentes de segurança as específicas dinâmicas do recrutamento infantil, de modo a frisar a posição de vítima da criança no conflito e qual poderia ser o papel de cada agente para a erradicação do fenômeno.

A linguagem aqui é ambígua assim como a posição do ser criança soldado e oscila entre, de um lado, a centralidade da criança como vulnerável e vítima do conflito promovido por adultos e, de outro, a prioridade da estabilidade e da preservação da ordem social, motivo pelo qual os agentes de segurança destinam suas missões. Isto é, o imaginário da criança inocente e vulnerável deve ser mantido no constante das missões até o aparecimento de um momento crítico capaz de reconfigurar a olhada do agente de segurança para a agora criança soldado em atuação como sujeito do conflito.

Esta posição binária, esse confronto que cerca o entendimento e discursos da criança soldado, ocupa as linhas deste manual de maneira que qualquer 'solução' ao 'problema' venha com um porém; as escolhas excludentes deixam rastros de

\footnotetext{
${ }^{15}$ Os regimes de verdade, para Foucault, operam como profecias autorrealizáveis. Como exemplo, os modos de pensar sobre a infância se juntam com as práticas institucionais a fim de produzir sujeitos autoconscientes que pensam e sentem sobre eles mesmos por meio dos termos daqueles modos de pensar. Assim, a 'verdade' sobre eles mesmos se apresenta como auto-validada. (Prout; James, 1990, p. 23).
} 
incoerências e desencaixes que produzem a criança soldado como 'crise' do contemporâneo, principalmente, "by contrasting the helplessness of children with an excessively idealized version of adult autonomy, independence, and maturity. " (Rosen, 2005, p.134). Pois, a presença da criança no conflito, dentre estas percepções, é compreensível através do papel de vítima, seu movimento no contexto de guerra permite sua 'natural' passividade, dada sua imaturidade e vulnerabilidade. Entretanto, como a criança soldado se apresenta também como participante do conflito, ela é capaz de embaralhar as imagens entre o adulto e a criança, entre a vítima e o perpetrador, sendo projetada como um ser desviante, uma anomalia em si.

Culturally speaking, not only are children not 'proper' military enemies, but, confronting them is experienced as an abnormal situation since such youngsters contravene assumptions and deeply held beliefs about children as innocents and vulnerable. (Ben-Ari, 2011, p.3).

Considerando-se o exposto, a pergunta que permanece na leitura do texto é: como, então, reconhecer "a criança" quando ela já não ocupa mais a posição da criança moderna no singular? Nesta interrogação, é mostrada a urgência por soluções capazes de “(re)colocarem a criança em seu lugar", tentativas que revelam a relação paradoxal e binária entre criança/adulto; conflito/paz; público/privada; vítima/perpetrador no que tange à produção da categoria (ex-) criança soldado.

Nessa perspectiva, quando o Relatório Machel traz a categoria da criança soldado como 'novo problema social', este, igualmente, explica tal fenômeno por meio de três pilares de entendimentos correlacionados: primeiro, a construção da criança como, essencialmente, inocente e vulnerável, incapaz de ser soldado; segundo, a criança soldado como marca da brutalidade das novas guerras nãoocidentais; e, por fim, a proliferação das armas pequenas e leves como facilitador do recrutamento infantil dentro do conflito armado moderno.

Segundo Rosen, o 'problema' das crianças soldado não se apresenta somente como um esforço humanitário para a proteção das crianças,

[...] but is part of a global politics of age in which humanitarian and human rights groups, sovereign states, and the United Nations and its administrative agencies battle over the rights and duties of children and over the issues of who is a child and who is a child soldier. $(2005$, p.2). 
Na configuração da política global, o conceito de criança soldado ganhou destaque e sua emergência na mídia e nos discursos das agências internacionais como 'problema social' ressalta a (re)produção de seu desvio à concepção dominante de infância moderna embasada na inocência e vulnerabilidade, cujo começo está no nascimento, tendo fim aos dezoito anos.

O primeiro pilar de entendimento do discurso da (ex-) criança soldado como 'novo problema', portanto, encontra-se na construção da criança como essencialmente vulnerável, inocente e irracional em consonância ao discurso da infância moderna ocidental. Necessariamente vítimas do conflito, as crianças postas em situações de risco estão em necessidade de proteção e salvamento, desse modo, as posições que ocupam são de incompetência e irracionalidade acerca das ações e decisões, pois a prática da guerra é tida como pertencente à esfera de atuação e decisão da vida adulta e não da infância moderna. As crianças, então, são projetadas como atores irracionais e emocionais, passíveis somente de sentir e acreditar e não de entender, julgar e decidir. (Rosen, 2005).

Somando ao exposto, de um ângulo, há a ideia de passividade e vitimização da criança soldado em relação ao seu envolvimento no grupo armado e sua inferioridade em relação ao ser adulto - coagida pela força e medo - e de outro, existe a mobilização de sua potencialidade para a morte e o caos ao atuarem de modo delirante estando sob efeitos de drogas e álcool, por exemplo. Sendo, em consequência, passíveis de manipulação pelos adultos com o intuito de cometerem atos criminais e/ou ilegais. "Weakened psychologically and fearful of their commanders, children can become obedient killers, willing to carry out the most dangerous and horrifying assignments." (Singer, 2005, p. 80).

Outrossim, existe o argumento de que a vulnerabilidade das crianças é o que as tornam valiosas nos serviços dos grupos armados, uma vez que, quando capturadas para tarefas militares, são ensinadas a matar, a limpar suas armas, a praticar hostilidades e a normalizar suas atitudes violentas, tornando-se obedientes a seus comandantes por medo, fraqueza ou disciplina; e, por não reconhecerem o perigo de suas ações, transformam-se em verdadeiros assassinos. Para esses discursos, a naturalização do comportamento violento é o que sustenta a hipótese da instabilidade sem fim, gerando um ciclo vicioso em que a criança abandonada, assustada e acostumada a lidar com hostilidades, 'doutrinada' desse modo, não consegue visualizar outra maneira de vida e de subsistência. E, em muitos casos, 
mesmo após o conflito, acaba retornando a seu estágio de soldado ou voltando-se ao crime. (Singer, 2001).

Portanto, as (ex-) crianças soldado orbitam em torno dos discursos que as caracterizam como incapazes, discursos esses que as reconhecem basicamente como vítimas do conflito em necessidade de intervenção e tratamento. Sua racionalidade, participação e responsabilidade são constantemente negadas nos tempos, de alguma forma, desde seu envolvimento no grupo armado, sua atuação em batalhas até sua categorização como ex-criança soldado. Assim sendo, os discursos mobilizados pelas agências internacionais e humanitárias "stress a single message: children are at serious risk. " (Tabak, 2015, p. 33-34, itálico no original).

Seguindo esta lógica da irracionalidade da criança, o recrutamento infantil como voluntário precisa vir sempre entre aspas, pelo fato de as crianças se mostrarem incapazes de optar ou não pela sua participação no grupo armado e de visualizarem as consequências dos seus próprios atos. Além disso, as condicionantes socioeconômicas estão sempre interferindo e deturpando suas escolhas; em cada situação e por trás de cada opção, existem fatores, ambientes e circunstâncias que condicionam a decisão das crianças de se envolverem em um grupo armado. Essas condicionantes são projetadas como causas, cuja permanência continuará incentivando a participação dos menores nos conflitos armados, como um ciclo vicioso.

Consoante esta discussão predominante, os motivos que levariam as crianças a optarem (entre aspas) pelo recrutamento, no sentido de negarem sua racionalidade, são múltiplos e igualmente capazes de traduzir a vulnerabilidade posta na criança e sua situação de risco, entre eles, destacam-se: ausência de perspectiva na vida; busca de estruturas básicas como alimentação, acomodação e roupas; ajuda financeira para a família por meio de salários que lhes são oferecidos; desejo de se empenhar em algo diferente; desconhecendo, todavia, as dimensões de estar envolvido na guerra; e vontade de estar engajado em algum tipo de treinamento ou educação. (Brett; Spetch, 2004, p. 112).

Nesses discursos da infância moderna, a concepção de recrutamento voluntário é mascarada e tida como contraditória por entre tais circunstâncias, logo, a escolha da criança já é, automaticamente, negada pelas situações de pobreza, miséria, abuso doméstico, morte dos pais, etc. É um termo sempre colocado entre aspas, anulando a própria possibilidade de ser um ato de livre escolha, o que 
constrói a incapacidade de decisão da criança, visto que sua racionalidade é desestabilizada pelas condições do contexto e seu envolvimento militar sempre uma falsa livre escolha. Creio ser importante destacar que problematizar esta narrativa é abrir espaços para outras histórias e estórias, cujos moldes não são compatíveis e não conseguem se encaixar nos planos e discursos da infância moderna em que a criança é posta na constante condição de vítima e vulnerável.

Diante desse panorama, percebe-se que as (ex-) crianças soldado são projetadas tanto como vítimas do conflito em uma posição de incompetência e irracionalidade na tomada de decisões quanto como incontroláveis ou selvagens, monstruosas e violentas não possuindo consciência ou controle sobre seu corpo e seus atos. Por mais que a criança consiga chegar a uma posição, tradicionalmente, reconhecida como adulta - a de combatente, por exemplo - ela a ocupa de maneira incompleta ou de forma emocional e delirante, necessitando de regulação e supervisão. Portanto, como potencial e ameaça, a vulnerabilidade da criança soldado traduz a ambiguidade do ser criança.

O segundo ponto conceitual que sustenta a narrativa da criança soldado como 'nova crise' do contemporâneo está relacionada ao desenvolvimento das 'novas guerras', um tipo de conflito específico com características diferentes das do tradicional, sendo conhecido, principalmente, pela sua brutalidade e constante desordem. "Conflicts around the globe are increasingly characterized not as temporary outbreaks of instability but rather as protracted states of disorder." (Singer, 2005, p. 52). Desse modo, esses conflitos "drag on for long periods with no clear beginning or end, subjecting successive generations to endless struggles for survival.” (Machel, 1996, p.14).

Kaldor (1999) afirma que estas 'novas guerras' necessitam ser entendidas no contexto de complexificação das interconexões globais do pós-Guerra Fria, como um novo tipo de violência armada organizada, capaz de resultar na opacidade entre as principais distinções presentes nos conflitos tradicionais. Assim, as fronteiras fundamentais acabam se tornando não diferenciáveis: seja entre o público e o privado; entre o território estatal e fora dele; entre atividade econômica e atividade estatal pública; entre civil e combatente, consoante se confirma na fala a seguir:

[...] the new wars involve a blurring of the distinctions between war (usually defined as violence between states or organized political groups for political motives), organ- 
ized crime (violence undertaken by privately organized groups for private purposes, usually financial gain) and large-scale violations of human rights (violence undertaken by states or politically organized groups against individuals). (Kaldor, 1999, p. 2)

Todos esses pontos que caracterizam os novos conflitos são capazes de mobilizar o discurso da (ex-) criança soldado como 'novo fenômeno global', dando como motivos o constante caos que afeta gerações e gerações e cuja estratégia de usar a criança soldado se torna uma alternativa não somente para suprir a demanda de combatentes, mas também para prolongar a violência. Consequentemente, "this creates the doctrine of child soldiers, a new way of enacting violence that prescribes the methods and circumstances of children's employment in battle." (Singer, 2005, p. 53).

Dessa forma, o argumento principal apresentado situa as guerras tradicionais em um patamar superior, ao contrapor suas autolimitações e seu caráter autorregulamentado ao caos e barbárie das novas guerras que trazem consigo o fenômeno da criança soldado. Seja no fator político, por não ter claros objetivos; temporal, por não possuir um claro começo e fim para a vitória e derrota; espacial, por não existir um espaço geográfico definido para o campo de batalha; e humanitário, por não ser possível distinguir entre civil e combatente.

Para Rosen (2005), os termos moderno, novo e tradicional, que qualificam os conflitos, são vagos e imprecisos, porém úteis para diferenciar e distinguir os conflitos étnicos e as guerras civil menores das guerras internacionais anteriores e as guerras de libertação nacional. A construção de linhas divisórias entre o 'velho' e o 'novo' permearam os discursos políticos, estratégicos e humanitários desde o fim do colonialismo e contribuem para a ideia de que esses novos conflitos, caricaturados como bárbaro e sem propósitos, são presenciados nos Estados póscoloniais e carregam em seu cerne o 'problema' das crianças soldado. Neste sentido, Rosen assevera que

[...] the child-soldier crisis is the crisis of the postcolonial state. For that reason the international community of humanitarian and human rights groups and of governments, once avid supporters of the armies of national liberation, have now redefined all rebels and their leaders as apolitical criminals and child abusers. (2005, p. 14). 
Sendo assim, "child soldiers appear, thus as a symptom that became a normalized mark of these new 'barbarous and uncivilized' wars"' (Tabak, 2015, p. 62). Segundo Macmillan (2009), ao colocar a criança soldado como símbolo das 'novas guerras', descredibiliza-se o protagonista, seus objetivos e os meios de alcançá-los. A autora salienta que os países ocidentais projetam uma identificação com as guerras tracionais (construídas como superiores), enquanto as crianças soldado (dentro das guerras bárbaras) se localizam longe em outros espaços, no mundo não-ocidental.

Todavia, o que está escondido nas entrelinhas dos discursos tradicionais é que milhares de crianças nos países ocidentais se encontram envolvidas nas forças armadas de seu Estado. Sendo assim, “contemporary discourses are shot through with colonial notions and child soldier constructions show great consonance with them." (Macmillian, 2009, p. 47).

O último pilar pelo qual a categoria criança soldado é construída como um 'novo problema global' se encontra na recente proliferação e no avanço tecnológico das armas leves, mais precisamente, das chamadas armas pequenas e leves (small arms and light weapons). Consoante Singer (2005), estas armas são as mais simples e também as de menor custo disponíveis, sendo capazes de permitir "the transformation of children into fighters just as lethal as any adult. " (p. 46); devido ao seu menor peso e fácil manuseio e transporte, elas são passíveis de serem utilizadas/ portadas por crianças.

O Small Arms Survey ${ }^{16}$ - um centro global de excelência especializado na produção de dados, evidências e conhecimento sobre todos os aspectos das armas leves e de violência armada - afirma que não há uma definição, universalmente aceita para armas pequenas e leves, entretanto, adota a portabilidade como o fator definidor. Ou seja, são armas tanto civis, privadas, quanto militares que lançam um projétil com a condição de que a unidade ou sistema seja levado por um indivíduo, um pequeno grupo de pessoas ou transportado por um animal de carga ou um veículo leve. Podem ser consideradas armas pequenas os revólveres, pistolas autocarregáveis, rifles e carabinas, metralhadoras e suas munições, etc., e em relação às armas leves as metralhadoras pesadas, lançadores portáteis de mísseis e sistema de foguete, entre outras. (Small Arms Survey, 2014).

\footnotetext{
${ }^{16}$ Para mais informações, acesse o site: <http://www.smallarmssurvey.org/home.html>.
} 
I carried an Armalite, an M16. I was trained on how to use a gun, how to fire it, how to dismantle and assemble it. That was the training I received. The training included hopping over rocks, crawling, rolling. That was for three weeks. [Ex-criança soldado de Papua Nova Guiné - recrutado quando tinha 14 anos] (UNICEF, 2002, p. 37).

Em 2014, o Small Arms Survey apontou quais foram os Estados que mais exportaram armas leves e pequenas (com cifra maior de 100 milhões de dólares em exportação): Estados Unidos, Itália, Brasil, Alemanha, Coréia do Sul, Áustria, Turquia, Federação Russa, República Checa, Bélgica, Croácia, Israel, Espanha, Suíça e Japão, sendo que os Estados que mais produzem estas armas são aqueles apontados como maiores exportadores. (Small Arms Survey, 2014).

Minha intenção, neste ponto, é mostrar que, ao relacionar o 'problema' da criança soldado com a produção e proliferação das armas pequenas e leves, esquecemos de problematizar os processos que tornam comuns a manufatura e o comércio dessas armas que chegam até as crianças soldado. Isto é, penso que se mostra necessário questionar a naturalidade de se produzir o 'problema' da criança soldado em conexão às armas leves e pequenas, não se atentando ao fato de que o 'problema' estaria ligado a uma estruturada estratégia de guerra e suas indústrias. Os maiores países exportadores de armas leves e pequenas estão em sua maioria localizados no Ocidente, transparecendo ideais de poder que embasam os discursos sobre a formação da categoria (ex-) criança soldado, suas causas e consequências.

Há que se atentar também para os discursos sobre a relação 'natural' e direta entre o avanço das armas leves e o fenômeno da criança soldado que se apoiam na curta duração dos treinamentos destinados à criança antes de sua atuação nos campos de batalha, como se verifica na seguinte passagem: "with only a few hours' training, a youngster can be taught all he or she needs to know in order to kill or wound hundreds of people in a matter of minutes. " (Singer, 2005, p. 47). Nesta discussão, entendo que o que vem a ser frisado é a facilidade de transformação da criança em soldado pela não necessidade de um treinado formal e especializado, seja por conta de sua vulnerabilidade na projeção do soldado incompleto (em relação ao ser adulto) e/ou pela própria evolução das armas, com as quais as crianças lidam como se fossem pequenos brinquedos (Singer, 2001). Em contraposição ao combatente adulto, a incapacidade e a vulnerabilidade da criança 
a jogam na posição do combatente imoral e incompleto, aquele inferior ao adulto, seja física seja racionalmente.

Dessa maneira, quando se parte da comparação com o soldado adulto, os aspectos físicos da criança (sua fraqueza e pequenez) logo aparecem como um fator de inadequação à vida militar, ou seja, "given this avowedly normative nature of the discourse, the characteristics chosen for comparison necessatily judge child soldiers to be inadequate." (Macmillian, 2009, p.42, itálico meu). No entanto, assim como Macmillan (2009) afirma, não existe uma relação direta e primordial entre a força física e ser um bom soldado.

Ademais, a visão de que a atual proliferação das armas leves é um dos fatores que leva, diretamente, ao uso da criança soldado não se apoia, segundo Rosen (2005) em nenhuma evidência empírica. Seu posicionamento se ampara no argumento de que a arma mais popular associada à criança soldado é a AK-47 (Russian Avtomat Kalashnikov odraztzia 1947 goda), instrumento já disponível desde as lutas de liberação nacional em 1949, antes da 'atual crise' das crianças soldado, e com peso de quatro quilos e 250 gramas aproximadamente, sendo igual ou superior aos rifles usados na guerra civil americana- onde se notava a participação de crianças nas batalhas.

De acordo com Rosen, é muito raro encontrar referências ou dados sobre a potencialidade de fogo, descrição e o peso das armas - ou até o que se entende por armas leves e armas pesadas - em relatórios sobre criança soldado no campo dos discursos que a categorizam, como dentro da UNICEF, por exemplo. E se a relação das armas pequenas e leves com a criança soldado tem a ver com o peso, as armas utilizadas por elas representam somente uma parcela do peso total carregado nas caminhadas, pensando nas cargas de munição e outros objetos para a sobrevivência. (2005). Logo, "in sum, small arms can be terrifying weapons of destruction, but their role as a factor in the child-soldier crisis is, at best, indirect." (Rosen, 2005, p. 16).

Por fim, os três pilares conceituais - construídos pelos discursos da 'frouxa coalizão', que norteiam a concepção do novo fenômeno das crianças soldado como crise - atuam de modo problemático ao buscarem formar específicas causas e consequências do atual recrutamento de menores e (re)produzindo uma concepção específica da criança soldado em contraposição ao ser criança e ao ser adulto, ambos no singular. $\mathrm{O}$ entendimento da criança soldado e da ex-criança soldado como 
problema social se baseia neste conjunto de causas e consequências que permeia desde a escolha de específicas experiências na construção da imagem de 'resgate' e 'salvação' das crianças associadas a uma força armada ou grupo armado até a fundação das concepções que orientam as inclusões e exclusões da narrativa da infância moderna e do conflito moderno. Quem/ quando/ como é podido ser criança? (Rosen, 2005). Além, das construções de um entendimento específico para a ex-criança soldado pelos discursos do trauma e da resiliência e suas relações.

\subsection{3}

\section{Ex-criança soldado e (pós-) conflito: o discurso do retorno}

O discurso do retorno, nesta minha análise, envolve as estratégias da reintegração social destinadas às agora ex-crianças soldado em necessidade de tratamento e de condução especial para que retornem ao ambiente civil de maneira 'satisfatória'. Por isso, por meio destas linhas, tento passar pelas práticas dos programas de Desarmamento Desmobilização e Reintegração para ex-criança soldado que, desde 2007, estão sendo chamados de programas de Liberação e Reintegração, com o objetivo de mostrar os argumentos que formam sua categoria e sua relação com o conflito e também com o pós-conflito. Para tanto, busco explorar a produção discursiva da categoria ex-criança soldado por entre os ideais de retorno à estabilidade e o modo como este retorno para as crianças da guerra se dá em relação às continuidades e descontinuidades da infância moderna e do conflito moderno pelos processos de desmobilização e reintegração social.

Como se dá a categorização da ex-criança soldado? Vem e vai junto com o conflito? Essas perguntas permeiam a discussão acerca do discurso do retorno e permanece nas histórias contadas pelas crianças por meio da conjugação de seus tempos verbais, pois quando são retiradas das "guaras do conflito", os processos de reintegração social tomam início. No momento em que a criança se desvincula do grupo armado e ainda é considerada uma criança pelo critério etário (menor de dezoito anos), a categoria de ex-criança soldado consegue vesti-la e, de repente, o prefixo temporal 'ex' entra em cena trazendo o ar do passado, mesmo que, em alguns casos, o conflito continue se desenrolando lá fora.

Assim fala este ex-menino soldado: 
When I was in the militia I was used to be alone and being independent. It's hard to go back living with parents after that. I didn't like living with my parents. I'm child, yes, in age, and in size I am still small, but I know so many things about the world that nobody can joke with me or tell me what to do. (...) I prefer to die a soldier. I want to go back to the bush to fight. If you die a soldier, your parents will be proud because you died on their behalf. Even your friends will be proud. If you die a civilian, you die in the hands of a machete in your home. That's a stupid pointless death [Ex-menino soldado, República Democrática do Congo]. (Children of conflict, 2007).

Desse modo, as descontinuidades que marcam a relação entre a categorização da ex-criança soldado e o conflito são desiguais e múltiplas, contudo são capazes de mostrar como a produção de sua categoria está camuflada entre os discursos da reintegração social, ainda que a desejada estabilidade social e política em seu contexto permaneça incerta. Este fato está ligado tanto aos ideais modernos do ser criança - (com base na inocência e vulnerabilidade) e da construída incompatibilidade entre os dois mundos: a infância moderna e a guerra moderna a não ser pelo olhar de vítima - quanto em relação ao desenho temporal que a excriança soldado movimenta entre passado e futuro.

É preciso salientar, outrossim, que a exclusão espacial da criança da esfera pública e da política, como no caso deste ex-menino soldado do espaço do conflito, coloca-a como pertencente, essencialmente à esfera privada, dentro do espaço da família. O processo de regulação e ordenamento da infância para a vida adulta cria espaços específicos para a rotina infantil, qualificando a vida pública como insegura para crianças, como exemplo extremo: a participação no conflito armado reflete um total desvio dos locais apropriados para o ser criança. Sendo assim, determinados espaços e contextos como a escola, o lar familiar e lugares de lazer infantil são designados como os únicos espaços possíveis de serem frequentados pela criança.

Portanto, os processos de retorno à vida social para as ex-crianças soldado se encaixam nesta narrativa da "infância perdida" na tentativa de "voltar a criança para o seu lugar" enquanto há tempo, confirmando que "reintegration programmes must re-establish contact with the family and the community." (Machel, 1996, p. 19), sendo que "education, and especially the completion of primary schooling, must be a high priority.” (Machel, 1996, p. 20).

Escola e família são os dois pilares fundamentais que acompanham o retorno das ex-crianças soldado ao meio social e que, igualmente, refletem um ideal específico de infância, cujas necessidades da criança, sejam físicas sejam 
emocionais, são universalizadas. Alicerçado a isso, as estratégias da reintegração social, assim, ganham formas pela reunificação familiar, frequência escolar e treinamento vocacional, primeiramente, a partir dos programas de DDR destinado às ex-crianças soldado e, depois, dos programas de Liberação e Reintegração

Num primeiro momento, o programa de DDR, voltado para ex-combatentes adultos e para ex-crianças soldado, é constituído por cinco estágios: entrega das armas, reuniões, saída/quitação, reinserção de curto e médio prazo e reintegração de longo prazo. (Ball; Van De Goor, 2006, p. 2).

O desarmamento corresponde à entrega, coleta, documentação e controle de armas pesadas e leves, explosivos e munições de combatentes e também de civis. A desmobilização compreende a saída formal dos combatentes das forças armadas ou de outros grupos armados e a entrada dos mesmos nos centros temporários de concentração das tropas. A reinserção é uma etapa intermediária - entre a desmobilização e a reintegração - e lida com a ajuda imediata concedida aos combatentes, como alimentos, roupas, tratamentos médicos, abrigos, etc., sendo vista como um apoio de curto prazo, a fim de sanar as necessidades básicas dos excombatentes e suas famílias. Por fim, a reintegração se refere ao processo pelo qual os ex-combatentes ganham o status civil e retornam ao meio social com um emprego estável ou algum meio de renda; é o estágio final do processo e corresponde a medidas a longo prazo para a estabilidade das estruturas políticas, sociais, econômicas e culturais do local para o nacional. (Ball; Van De Goor, 2006).

Em relação ao programa de DDR destinado às ex-crianças soldado, é recorrente encontramos, em algumas análises sobre o tema, os variados descompassos e impedimentos de seus procedimentos para a reintegração social das ex-crianças soldado ao ambiente civil, sejam referentes, por exemplo, à sua duração sejam aos seus recursos. Pois, além de serem uma adaptação do programa voltado aos combatentes adultos, o tempo previsto e os recursos disponíveis, muitas vezes, são insuficientes para cumprir as ações planejadas, acrescentando-se ainda o fato de que há as impossibilidades de interferir nas localidades e no contexto político local com um modelo fixo que estipule um certo padrão de se pensar a infância e o seu lugar.

Segundo Bhabha (2014), uma das falhas principais dos programas de DDR seria a relação temporal, isto é, o curto tempo proposto pela agenda humanitária não é compatível com a longa demanda dos processos de reintegração social das 
ex-crianças soldado, revelando certos descompassos entre o que se é oferecido e as suas necessidades. Além disso, o programa de DDR possui alguns outros obstáculos em relação à reintegração das ex-crianças soldado capazes de ser resumidos, de acordo com Bhabha (2014), por meio de: 1) discriminação na alocação de recursos provenientes do programa, o que cria ressentimento e inferioridade dentre os membros da comunidade, já que quem recebe os benefícios são os que praticaram a violência; 2) diferenciação de gênero, dando um tratamento inadequado às exmeninas soldado ou nem as reconhecendo como potenciais participantes do programa; 3) curto período do programa, que não corresponde às necessidades das ex-crianças soldado.

I was involved in the first DDR. But it didn't help me. It was of no use. The people eat the money. And there was also no good reintegration. And then I went fighting again. So now I'm not doing the DDR any more. [Ex-menina soldado, Liberia]. (Specht, 2009, p. 203).

A fala desta ex-menina soldado mostra como sua relação com os programas de DDR se deu de maneira negativa, ressaltando um certo desuso dos processos perante sua realidade social. A falta de suporte e a projeção de uma reintegração social específica, entre as muitas (des)continuidades temporais do contexto, traduz desvantagens sociais, políticas e também subjetivas que envolvem os ideais do discurso do retorno na vida das ex-crianças soldado.

Somam-se a esses fatores, outros que são ou foram apontados como obstáculos aos programas de DDR, como a utilização de modelos padronizados que estruturam os procedimentos do programa, silenciando as singularidades presentes nas localidades e implementando práticas incompatíveis com as realidades sociais onde as crianças serão reintegradas (Tabak, 2009; Bhabha, 2014; Verhey, 2001). Junto a isso, existe a dificuldade de englobar as demais funções das crianças soldado, não somente a de combatente, pois, em muitos locais, a chave de entrada nos programas de DDR era a entrega de armas (desarmamento), mas também a de reproduzir um padrão de infância universalizado e restrito à questão etária que não limitasse a participação no programa e as possíveis outras maneiras de se pensar a criança.

Todos esses fatores são apontados como enfraquecedores da 'bem-sucedida' reintegração social das ex-crianças soldado, tornando-as passíveis de retornarem à 
violência do conflito ou do pós-conflito, 'falha' esta tida pela incapacidade dos programas de DDR de construírem uma barreira vantajosa e definitiva - dentre a estrutura social - entre a infância moderna e o conflito moderno. Dessa forma, os programas de Liberação e Reintegração apresentados pelos Princípios de Paris, em 2007, vieram para cumprir esta demanda substituindo as práticas do DDR para as ex-crianças soldado, com o intuito de abranger todas as crianças associadas às forças armadas e grupos armados em caráter formal ou informal no desempenho de qualquer função, não somente a de combatente. Por essa razão, a noção de desarmamento e desmobilização não mais fazia sentido sob a ótica do aparato discursivo da categoria ex-criança soldado que deixava mais claro a imagem da criança (e seu direito de ser liberada) do que a do soldado.

Ademais, outro ponto que embasa o discurso do retorno para a ex-criança soldado se situa nas consequências emocionas e psicológicas que a exposição e participação da violência podem trazer à criança. Essa afirmação tem como suporte a narrativa naturalizada sobre a (ex-) criança soldado em que, uma vez acostumadas com a rotina dos grupos armados, doutrinadas e em contato constante com armas, munições e mortes, as crianças desconhecem a vida civil e/ou já introjetaram e naturalizaram a lógica militar. (Singer, 2005). A urgência em prover um tratamento adequado para a ressocialização das ex-crianças soldado é afirmada com a finalidade de produzir um 'aceitável' e específico ser adulto, pois "fear of transmission of violence justifies external intervention into the cultural processes of childhood socialization." (Macmillian, 2009, p. 44).

Nota-se, tendo como embasamento o supramencionado, que a ex-criança soldado já é projetada como traumatizada, machucada pelas feridas das guerras e com necessidade de tratamento psicológico especializado e medicalizado a fim de minimizar os efeitos do passado militar e/ou maximizar as oportunidades de superar tal passado através da projeção de um futuro estável; a relação entre construções de esquecimentos (subjetivos e temporais) e superação caminham juntos na produção da ex-criança soldado resiliente.

Todavia, abordarei essas discussões e reflexões no capítulo terceiro, porquanto em um primeiro momento, minha intenção foi mostrar o modo como a (re)produção da categoria ex-criança soldado se encontra camuflada e escondida nas entrelinhas do discurso do retorno, ressaltando que esta volta acaba envolvendo direções específicas para a reintegração social das ex-crianças soldado com base 
em um ideal de ser criança (discurso da infância moderna) e de se pensar o tempo (linearidade temporal moderna).

Parto, então, da concepção de que os entendimentos que cercam a categoria ex-criança soldado estão, intimamente, conectados a uma concepção de retorno: da infância moderna como período temporal da vida e/ou como produtora de certos comportamentos e espaços (escola e família). Mesmo que o contexto em que se situam as ex-crianças soldado ainda esteja na instabilidade política e social do conflito, a criança soldado é capaz de marcar seu status com o prefixo 'ex' ao se desligar do grupo armado e permanecer criança pela idade.

O ser ex-criança soldado, portanto, remete a uma esperada ruptura entre o militar e o civil e entre o conflito e a paz, porém, igualmente, movimenta ideias de continuidade e descontinuidade por entre sua relação incerta e desigual com a infância moderna e o (pós-) conflito. O ser da ex-criança soldado está nas possibilidades de produção de sua categoria, do seu status, de sua vida infantil e de sua alocação temporal.

\section{3 \\ Descaso e amparo: a infância temporal moderna e a posição de espera da criança}

Em muitos relatórios de ONGs sobre (ex-) criança soldado, como aqueles produzidos pela Child Soldiers International ou Save The Children, por exemplo, a diferenciação entre infância e vida adulta acompanha o critério etário presente na definição da CDC em seu artigo $1^{\circ}$, identificando o 'ser criança' através da delimitação etária da menoridade (qualquer indivíduo menor de dezoito anos de idade). Assim, internacionalmente, “ eighteen is the temporal point when age no longer matters" (Tabak, 2015, p.38), ou seja, este marco expressa o limite temporal da transição entre o ser criança e o ser adulto. Tal divisão etária já consegue excluir uma vasta pluralidade de se pensar a infância em cada ambiente social e formula uma específica maneira de se desenharem as linhas que separam o mundo da criança e do adulto. (Denov, 2010).

Por conta disso, creio ser importante, neste momento, traçar as diferenciações entre estes três conceitos: criança, crianças e infância, pois, muitas vezes, esses vocábulos são utilizados indiscriminadamente, sendo a criança no singular capaz de abranger toda uma categoria explicativa e generalizar suas definições. Desse 
modo, é o termo infância o único capaz de englobar a temporalidade do desenvolvimento da vida das crianças, representando um conceito analítico e explicativo sobre uma fase particular da vida humana. (James, 2004).

Já o termo crianças classifica o conjunto de pessoas que habitam esta fase ou tempo da vida chamado infância, ou seja, é um conjunto de indivíduos que compartilham similares características (sejam biológicas e sociais) dentro do tempo da infância. Por fim, o conceito criança marca a posição do ator social individual, de sua singularidade, no entanto, como afirma James (2004), "our day-to-day encounters with the individual child are necessarily informed by our understanding of the analytical concepts of childhood and children, but they are not - or should not be - dependent on them.” (p. 34).

Dadas essas produções conceituais e suas diferenciações, nesta parte, portanto, procuro apresentar como a infância moderna é construída por entre pilares temporais específicos capazes de traduzirem os movimentos temporais da categoria ex-criança soldado dentro do discurso do retorno junto com os do trauma e da resiliência. Além disso, essas diretrizes sobre o tempo da infância são responsáveis também por estipularem uma certa relação linear e natural entre o passado, o presente e o futuro relacionados à transição da criança soldado para ex-criança soldado e desta para o ser adulto.

A realidade social da criança e do adulto são construídas como essencialmente diferentes, enquanto a criança necessita ser protegida e cuidada, os adultos são assumidos como indivíduos racionais, competentes e autônomos, sendo os únicos capazes de prover a segurança e proteção às crianças. Segundo Jenks (2005), a imagem do ser criança somente consegue ser imaginada em relação a uma concepção de adulto, ou melhor, “ it becomes impossible to generate a well-defined sense of the adult, and indeed adult society, without first positing the child" (p. 3). Consequentemente, a relação entre criança e adulto perpassa os entendimentos, neste caso temporais, construídos para estas duas categorias sociais como distintas ao traçar as linhas divisórias e os limites para a infância, sejam espaciais ou temporais, em contraposição à adultez.

A recomendação elaborada por Machel no livro Seen but not heard: plac-ing children and youth on the security governance agenda (2009), editado por David Nosworthy, reforça esta distinta posição da criança em relação ao adulto na seguinte passagem: 
Children in every country, and in every culture, occupy a central place in society. They are a symbol of innocence, and they represent the continuity of life. However, the translation of this centrality into the building of a protective environment for them has failed almost universally. (Machel, 2009, p. vii).

Neste sentido, ao representarem a continuação da vida e o futuro da sociedade, as crianças são postas em uma condição temporária - no período transicional da infância - dentro da metáfora do crescimento e do desenvolvimento humano, em que o sujeito incompleto e imaturo da criança espera para poder ser adulto e pertencer à esfera social, tendo em vista que "this adult world is assumed to be not only complete, recognizable and in stasis, but also, and perhaps most significantly, desirable.” (Jenks, 2005, p.8).

A posição de espera da criança orienta seus comportamentos e sua participação social para o futuro, sendo o presente apenas um estágio de preparação e aprendizagem, identificando a etapa da infância, portanto, como temporária e 'em construção', como se a criança fosse incompleta por natureza e somente o progresso e o desenvolvimento social e etário a levassem ao mundo adulto. Desse modo, a infância se constitui, de um lado, como uma fase transitória a partir do processo da criança de tornar-se (human becoming), cujos esforços são dirigidos para o futuro, enquanto, de outro lado, a realidade do ser (human being) pertence à vida adulta, cujo sujeito se apresenta como completo, competente e estável. (Qvortrup, 2004).

O binarismo do human being (ser) e human becoming (tornar-se) é visto como um fator analítico central para entender a interação entre o momento presente da criança e seu futuro, guiando a maioria das pesquisas no campo da infância, discussão esta que irei aprofundar no quarto capítulo. (Hanson, 2017). De acordo com esta concepção, "it is the fate of children to be waiting. They are waiting to become adults; to mature; to become competent; to get capabilities; to acquire rights; to become useful; to have a say in societal matters; to share resources. " (Qvortrup, 2004, p. 267).

Sendo assim, "it is possible to say that the child is included in the social realm through precisely his/her exclusion in the present time." (Tabak, 2015, p. 39, itálico no original). A evolução linear que cerca o desenvolvimento humano opera em termos de gradualismos de maturidade em que a infância, dentre uma vertente teleológica, é explicada pelo já pré-estabelecido final: a vida adulta. (Jenks, 2005). 
As posições temporais e as temporalidades que formam a criança orientam tanto seu processo de crescimento para tornar-se um adulto, quanto noções de ser a esperança para o futuro da sociedade (o que permite sua instrumentalização) e, igualmente, da infância nostálgica do agora adulto que olha para trás. Dessa forma, as múltiplas relações temporais e emocionais do adulto com a infância traduzem esta produção específica da criança inocente, vulnerável e sem responsabilidades que modelam o imaginário da infância moderna e sua alocação temporal.

As noções temporais desenhadas para a 'criança natural' têm base em sua imaturidade biológica e física e são tomadas como pilares do discurso do desenvolvimento social e do desenvolvimento infantil, sendo capazes de uniformizarem e padronizarem as experiências da infância através da delimitação das universais necessidades básicas da criança. Ou seja, estas necessidades, como carinho e proteção, por exemplo, são tidas como intrínsecas às crianças, como se representassem algo de sua própria natureza, e não como socialmente produzidas. Assim, “ 'children's needs' are understood as unquestionable facts rather than being socially constructed, culturally specific and, thus, a matter for political discussion". (Tabak, 2015, p. 43).

Procuro, neste momento, traçar, brevemente, um panorama sobre o discurso do desenvolvimento infantil (produção temporal da infância) de modo que as reflexões aqui iniciadas se conectem com as discussões sobre a narrativas do trauma e da resiliência para a ex-criança soldado do próximo capítulo. Apoio-me, de maneira geral, nas perspectivas que englobam as áreas dominantes do desenvolvimento infantil como Pedagogia, Psicologia e Pediatria as quais enxergam a criança como membro da sociedade 'em formação', sendo a sociedade equalizada como a sociedade adulta, uma vez que "children are thus, by definition, excluded from society, since their integration into it marks the fact that their childhood has come to an end". (Qvortrup, 2009, p. 24)

O discurso do desenvolvimento infantil concentra sua dinâmica na concepção de transição pessoal e individual em que a criança - no singular - encontra-se imersa no processo cheio de grandes mudanças até a adultez, sejam elas: sexuais (imaturidade para maturidade), cognitivas (incompetência para competência), motoras (incapacidade para capacidade), entre outras. (Qvortrup, 2009). Essa concepção de evolução linear da infância à vida adulta, juntamente com os discursos do desenvolvimento infantil, conseguiram modelar certos estágios e graus 
no decorrer do processo em que as crianças são passíveis de comparação, sendo caracterizadas como adiantadas ou normais ou atrasadas em relação a um caminho específico. $^{17}$

Foi, predominantemente, o discurso do desenvolvimento infantil dentro da Psicologia que articulou as bases de explicação sobre a natureza da criança e justificou a concepção de naturalidade da própria infância, sendo, até recentemente, a área dominante na análise da infância. Esta perspectiva dominante da Psicologia concentrou seus estudos na ideia do crescimento natural da criança, de sua evolução linear da simplicidade rumo à complexidade do mundo adulto, sendo capaz de conectar os aspectos biológicos com os do desenvolvimento social. (Prout; James, 1990).

\begin{abstract}
A key concept in the dominant framework surrounding the study of children and childhood has been development and three themes predominate in relation to it: 'rationality', 'naturalness', and 'universality'. These have structured a mode of thought which stretches far beyond the disciplinary boundaries of psychology, influencing not only sociological approaches to child study but the socio-political context of childhood itself. (Prout; James, 1990, p. 10).
\end{abstract}

Durante a década de 1950, tais temas predominantes do estudo da criança presentes na Psicologia adentraram o campo da Sociologia na forma das chamadas teoria de socialização, no qual, foram oferecidas explicações científicas para entender o processo de aprendizado social em que a criança (naturalizada e universalizada) é ensinada a se inserir na sociedade. A socialização, portanto, como processo de transformação social da criança para o adulto seguiu os estudos do campo da infância dentro da Sociologia, articulando ideias de 'bem-sucedidas' e 'falhas' socializações em que a criança é colocada dentro de um processo de crescimento social específico. (Prout; James, 1990). Por assim dizer, penso que a ideia de sucesso ou falha deste processo está, intimamente, ligada ao desejo de permanência de determinada ordem social. Destarte,

\footnotetext{
${ }^{17}$ Estas divisões entre estágios pré-determinados que levam as crianças para a gradual aquisição da competência lógica (marca da racionalidade adulta) foi proposta por Piaget (1986) ao encarar o desenvolvimento infantil como uma estrutura particular. O trabalho de Piaget influenciou e ainda influencia vários campos de estudos no que tange à infância e também a práticas sociais como, por exemplo, as práticas educacionais. (Prout; James, 1990).
} 
the child is assembled intentionally to serve the purposes of supporting and perpetuating the fundamental grounds of and versions of humankind, action, order, language and rationality within particular theories. (Jenks, 2005, p.27).

Ademais, destaco que os processos de reintegração social das ex-crianças soldado, como analisados anteriormente, igualmente, movimentam concepções acerca da socialização e de seus caminhos em relação ao (re)aprendizado social das crianças desvinculadas dos grupos armados que agora necessitam desenvolver habilidades para a conivência do ambiente social. Esta visão, embutida nas linhas do discurso do retorno, remonta a um certo ideal de ser criança na projeção de um passado 'positivo' em contraposição ao passado militar 'negativo' e também de se pensar a infância em termos unificantes a partir do desenvolvimento infantil agora relacionados ao ideal de superação do passado militar.

Essas relações temporais entre a criança soldado, ex-criança soldado e o adulto são muito mais plurais e ambíguas do que a concepção linear do tempo moderno consegue mostrar, por isso, aprofundarei essa discussão no próximo capítulo. Quanto aos desenhos temporais para a (ex-) criança soldado, esses deslizam, em minha discussão, de modo a complicar o discurso do retorno que formam a sua categoria e a alocam no tempo. Visto que "complicating our understanding of temporality is crucial for theorizing childhood and children's subjectivity." (Conrad, 2011, p. 206).

Seguindo as reflexões de Conrad (2011), consigo reconhecer as possibilidades de interrogar o modo como nossas miradas para o passado, presente e futuro são direcionadas a partir de uma concepção una do sujeito temporal adulto. Nossos entendimentos sobre o tempo e a infância são guiados, basicamente, pela visão do sujeito adulto - por sua 'natural' habilidade de se pensar sobre isso interpretando o ser criança como passado que está se transformando em direção ao futuro. Esta premissa sobre o tempo limita a possibilidade de compreendê-lo pela ótica das crianças ou de aprender como as crianças se imaginam em relação ao tempo e como este atua em suas vidas.

Por isso, percebo como o escutar das histórias e estórias das ex-crianças soldado vão criando outras narrativas plurais sobre seus envolvimentos com o grupo militar e suas relações com o passado militar. No passo dessa escuta, reconheço as limitações, ambiguidades e porosidades que cercam os processos de tradução dos nossos mundos, seja o infantil seja o adulto, à medida que 
[...] as we listening to children we need to be careful that we know how to hear what they are saying, through acknowledging that theirs words and ideas may be filtered, obscured, or muted by the constructs of childhood that shape our conceptualization of the life course. (James, 2004, p. 33).

Face ao exposto e na tentativa de questionar estas discussões sobre as concepções temporais da infância moderna e o modo como são construídas a partir de uma linear relação entre passado/presente/futuro, apresento reflexões sobre a categoria da ex-criança soldado junto com as demais temporalidades que a formam, tendo como baliza o fato de que a categoria ex-criança soldado e sua alocação temporal se tornam a pergunta em si no momento em que os discursos da infância temporal moderna são (re)produzidos. Entre o 'estar traumatizada' e o 'ser resiliente', os relatos das ex-crianças soldado sobre o passado militar e seus anseios para o futuro se mostram ajeitados em ideias de superação e esquecimentos. Assim, qual (ou quais) história(s) pode(m) aparecer? Em qual (ou quais) tempo(s) verbal(is)?

\subsection{1 \\ As múltiplas temporalidades e o ser (ex-) criança soldado}

As estabelecidas alocações temporais do ser (ex-) criança soldado, através dos discursos do retorno, buscam articular um determinado sentido para as relações entre passado/presente/futuro e suas demarcações arbitrárias nas histórias das excrianças soldado, principalmente, entre passado militar e futuro adulto. Dessa maneira, procuro aqui trazer as reflexões e os pensamentos questionadores desta produção arbitrária de linhas divisórias entre passado, presente e futuro que projetam um certo entendimento sobre o tempo, além de mostrar como a linear relação de evolução entre passado e presente, por exemplo, demarca um momento específico para se adereçar ao passado como tempo acabado.

Fasolt (2004) afirma que a construída distinção entre o passado e o presente foi fundamental no direcionamento da concepção do sujeito adulto soberano e autônomo com liberdade de ser e agir no agora, visto que o passado como um pedaço da realidade, em contraposição ao estar no presente, é marcado como um tempo acabado, ausente e imutável. Essas características do passado como tempo acabado e imutável dão ao presente a mutabilidade e a possibilidade de o sujeito 
poder ser e transformar os rumos futuros. Além disso, o passado é construído como ausente das relações estabelecidas no presente; recolocado em um outro momento, o sujeito adulto moderno autônomo é capaz de se desprender e de se libertar das amarras do passado, tomando controle de seu destino no presente.

Desse modo, ideias de liberdade e progresso se encontram embasadas nesta distinção entre passado e presente a qual, igualmente, difere o presente do passado "as subjects differ from objects of agency and knowledge, as reason differs from custom, and as responsible adults differ from the children they once were. " (Fasolt, 2004, p. 9). Somente seres humanos adultos e autônomos moralmente, portanto, são projetados como capazes de controlar o presente e se emancipar do passado. Assim como no discurso da infância temporal, a divisão entre passado e presente também se encontra na relação com a própria construção de uma infância de incapacidade e irracionalidade.

Contudo, de mesmo modo como Fasolt (2004), entendo que a fixação de uma linha divisória entre passado e presente é extremamente duvidosa e arbitrária, apresentando-se, mais precisamente, como uma construção que estipula um entendimento específico sobre o tempo a partir da linearidade de um fluxo sem interrupções. Sendo assim, esta distinção produzida entre os marcos temporais traduz a ilusão de se projetar o passado como acabado e imutável e o presente como espaço e tempo de autonomia, sendo passado "anything at all, it is a dimension of the present and changes along with it." (Fasolt, 2004, p. 16).

Apresento, portanto, neste momento, a discussão das temporalidades críticas elaboradas por Shapiro (2016), cujo interesse se encontra na análise de como os eventos podem ser pensados e desenhados a partir do relacionamento com uma gramática específica. Por meio do futuro anterior, will-have-been, Shapiro expressa como os eventos do passado reemergem no presente e vão perdurando por entre futuros contingentes ao remodelarem suas relevâncias políticas. Acredito que reconfigurar e abranger as interpretações sobre os eventos e as temporalidades é essencial para complexificar e questionar a linearidade temporal moderna e suas divisões arbitrárias em que as histórias e narrativas sobre as (ex-) criança soldado são produzidas e reproduzidas.

Mostro a análise temporal feita por Shapiro (2016), no seu capítulo Hiroshima Temporalities, como modelo de estudo a ser utilizado em minha abordagem sobre a produção temporal da categoria (ex-) criança soldado. No capítulo, o autor busca 
questionar a unidimensionalidade da concepção temporal moderna e suas divisões estabelecidas e fixadas ao mostrar como o evento da bomba de Hiroshima é permeado por uma multiplicidade de temporalidades que coexistem na (re)produção das histórias e narrativas. Por meio da metáfora do cogumelo e da água-viva, o autor apresenta como as memórias dos Estados Unidos e do Japão sobre lançamento da bomba são construídas e presenciadas de modo diferente. $\mathrm{Ou}$ seja, enquanto a história estadunidense se apresenta como distante e abstrata em relação ao evento, remetendo à estratégia que colocou fim à guerra (assemelhandose a uma lógica fotográfica da bomba: o cogumelo de fumaça), diferentemente, o Japão compartilha experiências mutáveis e dinâmicas, cujas lembranças se mantêm presentes e ativas no dia-dia dos participantes (lógica de ação cinematográfica que compara o lançamento da bomba a uma água-viva).

Shapiro entende que as relações interpretativas de Hiroshima, principalmente, dentro dos variados gêneros artísticos, continuam reemergindo nas histórias e narrativas, reafirmando, continuamente, as vidas dos indivíduos que lidaram diretamente com as consequências do evento, representado, por isso, como um "never-ending event" (2016, p. 36). Como exemplo, Shapiro traz a análise do livro Hiroshima after Iraq de Rosalyn Deutsche para articular o modo como os eventos se relacionam ados com a gramática do futuro anterior, em que os movimentos do passado habitam o futuro. Isto é, a partir de interpretações do evento da Guerra no Iraque, os encontros com Hiroshima ganham novas relevâncias políticas.

Tais reflexões críticas sobre o tempo, capazes de incomodar os modos oficiais de se pensar a História e sua linearidade entre passado, presente e futuro trazem histórias e estórias outras de temporalidades vividas pelos diversos grupos humanos por meio de rupturas, descontinuidades, coexistência e multiplicidade, sendo possível ressaltar, igualmente, a relevância de outras narrativas e olhares na construção de um 'evento'. Portanto, assim como Shapiro se apoia na análise de filmes, penso que outros gêneros artísticos, como exemplo a literatura e a fotografia, são capazes de mobilizar e redefinir nossas interpretações sobre o momento e o tempo.

Desse modo, nesta minha análise, com o objetivo de questionar a temporalidade moderna e a coesão em que o passado, presente e futuro são arrumados nos discursos do trauma e resiliência para a ex-cirança-soldado, pretendo também realçar as ambiguidades e multiplicidades das histórias e estórias outras 
que se ajeitam nos contos e nos pontos dos gêneros artísticos, capazes de mobilizar ora fixidez ora descontinuidade e fluidez.

Em virtude dos motivos levantados, aqui tento retratar como o menino soldado Agu do filme Beasts of no Nation (2015), que representa, sob meu enfoque, um sujeito estético, é capaz de traduzir, em alguns momentos, as ambiguidades da categoria (ex-) criança soldado e as pluralidades de sua difusa posição temporal. As relações temporais difusas e múltiplas são perceptíveis no movimento de Agu, em uma cena em destaque que transmite a confusão de seus reflexos no mundo e sua posição temporal como interrogação.

Ei-la: Agu está junto aos outros garotos do grupo prestes a invadirem uma casa na cidade onde, possivelmente, sua mãe, seu irmão e sua irmã estariam. Há poeira voando sob a atmosfera da varanda, a porta é aberta com força, a subida das escadas é sentida pelo barulho das armas pesadas se movimentando junto aos corpos dos meninos; lá em cima, Agu derruba os móveis desesperadamente e corre por entre os espaços como se buscasse algo. No quarto, eles encontram uma mulher escondida dentro do guarda-roupa junto com uma menina pequena, quando Agu avista a mulher, identifica-a como sua mãe, ele a chama de mãe, corre a fim de abraçá-la, e seu abraço causa um grande desespero à mulher que, assustada, diz não ser sua mãe. Entretanto, Agu permanece agarrado em suas pernas, de cabeça baixa e extasiado de emoção. No momento em que seus olhos encontram o rosto da mulher, ele reconhece que cometeu um erro e se afasta, imediatamente, gritando e xingando-a

Este movimento parece refletir a difusa alocação temporal de Agu na cena, pois há uma sobreposição entre o presente do ser criança soldado com um passado infantil ideal (dentro do discurso da infância moderna), cuja figura da mãe reafirmava relações de desamparo e cuidado. A emoção, o afeto e a necessidade de cuidado projetados em Agu, naquele momento, enquadram-no nas relações temporais do ser criança dentro do discurso da infância temporal moderna vulnerável, irracional, inseguro. Ao mesmo tempo, sua posição como criança soldado no presente, portando uma arma e envolvido no grupo armado, transporta noções de independência e violência incompatíveis com o tempo da infância moderna e mais bem acomodada no mundo adulto. Suas imagens plurais se misturam na cena e traduzem as relações ambíguas e difusas entre a infância moderna e o conflito moderno e suas temporalidades descompassadas. 
Dessa forma, a projeção da categoria criança soldado no presente como 'problema' transparece a impossibilidade de ajeitar a concepção da criança inocente na presença de seu envolvimento militar sendo, mais bem descrito quando o tempo do envolvimento militar é conjugado no passado e quando é possível trazer expressões como "retomar a infância perdida" nas linhas do discurso do retorno. Por conta disso, a coexistência das temporalidades entre o presente do ser criança soldado e o passado infantil, construído como ideal e projetado na cena pela figura da mãe, retoma um passado impossível de permanecer no presente da categoria criança soldado pelo discurso tradicional, vindo somente quando o sujeito resiliente busca narrar sua história de superação. Além disso, noto como as ambiguidades temporais que o sujeito estético do menino soldado Agu refletem - por meio da divisão construída entre um passado infantil e o presente da criança soldado trazem também questões sobre as divisões (re)produzidas entre criança/adulto; conflito/paz; vítima/perpetrador, entre outras.

Por fim, são também nessas múltiplas temporalidades que os discursos do trauma e da resiliência para a ex-criança soldado vão sendo desenhados, por mais que eles tentam estipular relações temporais lineares entre, principalmente, o passado militar negativo e o futuro do adulto e suas linhas divisórias, as histórias e estórias das ex-crianças soldado trazem as difusas experiências de (des)encontros com o (pós-) conflito.

\subsection{2}

As histórias e estórias de (des)encontros: a conjugação da excrianças soldado no (pós-) conflito

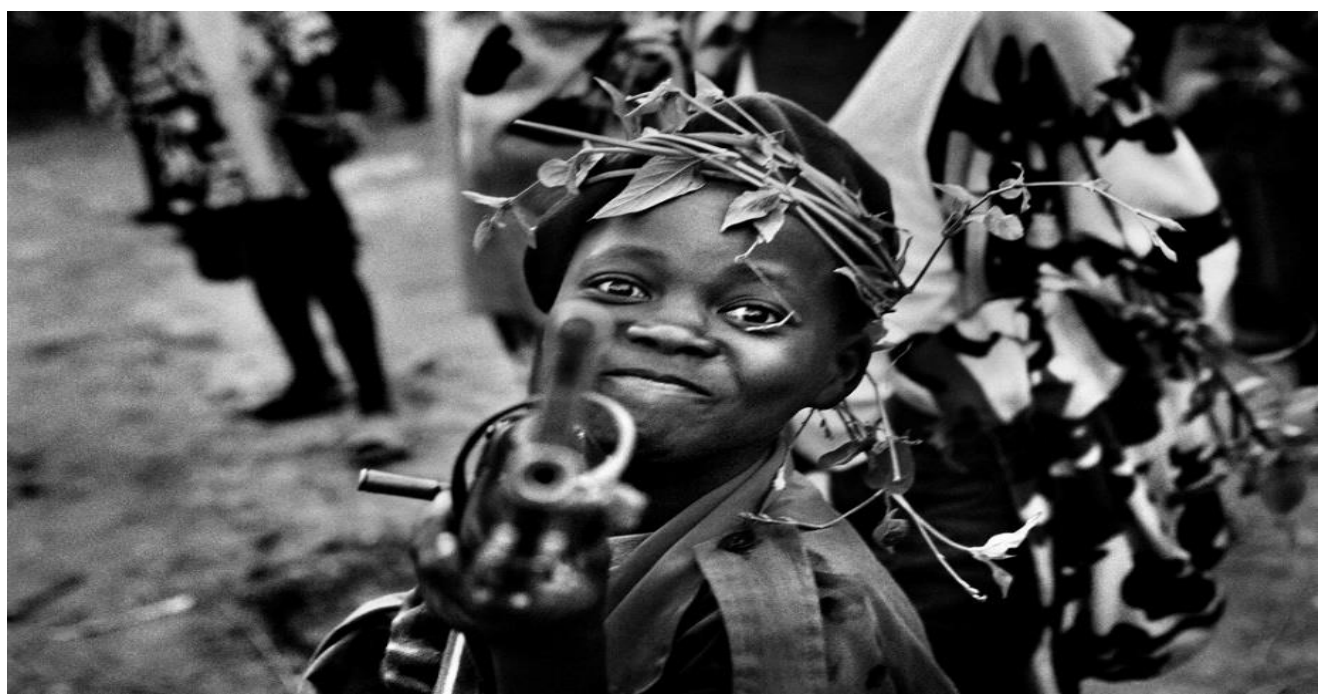

Figura 2: Foto do ensaio The rape of a Nation de Marcus Bleasdale, 2008. 
Esta foto desloca olhares, movimenta reações e explicações sobre o encontro dos dois mundos construídos, cada vez mais, como incompatíveis: o da infância moderna e o do conflito armado moderno e suas temporalidades. A criança por trás da arma congela um certo sentimento de insegurança e desordem social mantidos em preto e branco por entre as expressões guardadas em sua face. Além disso, o desenho das temporalidades que coexistem durante a posição de ataque da criança soldado busca englobar as histórias e estórias por trás dos múltiplos e ambíguos (des)encontros da criança no singular e do (pós-) conflito armado contemporâneo. Por isso, vejo que as (des)contínuas posições temporais da categoria (ex-) criança soldado mostram o quão intensa é a presença da arma de fogo no clique a fim de produzir um determinado entendimento da criança soldado no presente.

A presente descrição dessa foto conta, brevemente, uma trajetória deste menino soldado, que participa da milícia Mayi-Mayi (dentro da República Democrática do Congo). Naquele momento em 2008, estava esperando em Kanyabyonga enquanto os rebeldes avançavam. Ele não quis ser forçado a lutar, então, voluntariou-se para as fileiras do grupo armado não-estatal de Mayi-Mayi. ${ }^{18}$ São esses os fatos.

A imagem consegue traduzir em si a construção do nosso imaginário sobre a criança soldado ao encaixar os dois principais elementos estéticos em um mesmo clique: a criança no singular e a arma de fogo; a criança que carrega a arma, que aponta a arma, que já é a arma. Dessa maneira, é como se "the gun essentially defining him" (Denov, 2010, p. 1) e ficamos sem saber se ele (pois, raramente encontram-se imagens na mídia retratando meninas soldado) tem uma história além da arma. Seguindo as perguntas de Denov (2010), igualmente, questiono-me: O que aconteceu com esse garoto? Como ele está agora? Ele conseguiu superar seu passado violento e adotar uma identidade civil? Ele, um dia, adquiriu o prefixo 'ex'?

Todas essas perguntas permanecem nesta foto e também em outras cujo foco é a criança soldado e seu entendimento, ou melhor, o ser criança no singular junto com sua arma de fogo (geralmente uma AK-47). Todavia, estes retratos sobre o ser

\footnotetext{
${ }^{18}$ Informações disponíveis no site do fotógrafo Marcus Bleasdale no ensaio The Rape of a Nation. Disponível em:

<http://www.marcusbleasdale.com/new-gallery/w5wdwwbs8jg88hl05mo9hpcb97r17z>. Acesso em: 28 out. 2017.
} 
(ex-) criança soldado, (re)produzidos por um discurso temporal unidimensional e genérico, limitam as aparições das estórias sobre as vivências e experiências (des)contínuas da (ex-) criança soldado em relação ao (pós-) conflito, o qual envolve muitas outras descontinuidades e ambiguidades do que sua categoria fixada é capaz de englobar. Conforme Denov, as (ex-) crianças soldado são retratadas pela mídia mundial e também dentro dos discursos políticos por meio da lógica dos extremos: ora como perigosas ora como vítimas e, mais recentemente, como heróis redimidos (p.6).

While these children are frequently constructed through the logic of extremes (as either extreme victims, extreme perpetrators or extreme heroes), in reality, the lives, experiences and identities of these children fall within the messy, ambiguous and paradoxical zones of all three, which proves to be one of the most challenging aspects to contend with in their post-conflict lives. (Denov, 2010, p. 2).

Nesta parte da análise, busco, portanto, mostrar como estas imagens associadas às (ex-) crianças soldado conduzem a um determinado discurso acerca do tempo e dos espaços esperados para suas histórias e estórias; sendo que o que ganha destaque na mídia internacional, por exemplo, são os fatos que justificam certos desvios e possibilidades para essas crianças, seja da infância moderna e/ou de sua alocação temporal, para pensá-las através da lógica dos extremos. Tal lógica silencia a ambiguidade e a pluralidade que perpassam as experiências, as vidas e movimentos das (ex-) crianças soldado, além de retratar uma determinada relação, quase automática, da criança com o (pós-) conflito através da reintegração social e da ruptura com o passado militar. Por esse motivo, procuro aqui me envolver nos relatos das ex-crianças soldado, capazes de desapontar os discursos que as encaixam em imagens pré-determinadas e que as camuflam dentre uma concepção de retorno e de ruptura temporal.

Essa imagem vai continuar trazendo mais perguntas e incômodos e, ao mesmo tempo, mais abertura para questionar os binarismos formadores de nosso entendimento sobre o adulto e a criança; o conflito e a paz; o passado e o futuro. Depois de apresentar a construção das imagens para as (ex-) crianças soldado, pautadas na lógica dos extremos, meu intuito é trazer a discussão sobre a formação da categoria (ex-) criança soldado através da montagem de suas singulares falas no intuito de desestabilizar, temporalmente, o discurso tradicional do retorno e também 
de nos levar a um enredo de (des)continuidades entre o passado, o presente e o futuro e as múltiplas temporalidades que os (re)montam.

Sendo assim, primeiramente, a imagem de perigo e desordem - ou melhor, das (ex-) crianças soldado como bandidas, bárbaras e selvagens, conscientes de suas ações violentas e que, naturalmente, voltariam a perpetuar a desordem e o caos no pós-conflito - encena o risco proveniente do desvio da ideal infância moderna desejada e naturalizada. Neste sentido, ao tratar as (ex-) crianças soldado como monstros, não-civilizadas e incapazes de conviver harmonicamente no meio social, os discursos políticos dominantes, da mídia, das agências internacionais e também do campo acadêmico tendem a encarar tais crianças como indivíduos patológicos, como impuros e desviantes do caminho inocente da infância e, consequentemente, necessitados de intervenções externas e tratamentos médicos. (Denov, 2010).

Em outra vertente, as (ex-) crianças soldado são também projetadas como extremas vítimas indefesas do conflito, uma das imagens mais recorrentes nos discursos dos grupos humanitários que enxergam a criança no singular como, essencialmente, inocente, vulnerável e indefesa, sendo objetos passíveis de manipulação do adulto. Esta visão, articulada aos discursos humanitários, facilita o recolhimento de ajuda e suporte internacional, tanto para as ONGs que atuam na causa como também para a UNICEF e outras agências da ONU. O imaginário da (ex-) criança soldado como vítima desafortunada auxilia na arrecadação de ajuda humanitária, principalmente, devido à comoção popular e ao impacto gerado pelo slogan das crianças soldado como 'problema social' em necessidade emergencial de 'salvação' ou 'resgate', possível apenas com a interferência externa. (Denov, 2010).

A terceira imagem, a do herói redimido, conota outro tipo de relação mais recentemente inserida na mídia ocidental. Embora, durante a Guerra Civil Americana, por exemplo, garotos-soldado tenham sido projetados como heróis valentes e destemidos, que participaram da história do país, atualmente as referências para as histórias das ex-crianças soldado são construídas sob um status de celebridade e estrelato, principalmente, daquelas que agora vivem em países do Ocidente. (Denov, 2010). Elas são referidas como valentes sobreviventes, que lutaram bravamente contra as violências e mazelas do conflito armado moderno e seus discursos conseguem implantar a ideia de que, apesar de grandes adversidades, elas conseguiram ser resgatadas e superar o perigo. Ou seja, "the contemporary 
former child soldiers are considered heroes precisely because they survived the war circumstances, were able to get through the fighting memories and, in this sense, could 'reset' their 'natural' developmental course as a child." (Tabak, 2015, p. 141).

Existem vários exemplos de (ex-) crianças soldado, já adultas que contam suas trajetórias na mídia internacional; trago, como exemplo, o Ishmael Beah, autor do best-seller "Muito longe de casa: memórias de um menino-soldado" - texto que será analisado no próximo capítulo - e o cantor de hip-hop Emmanuel Jal. Seus discursos são capazes de conduzirem a um imaginário sobre o ser criança soldado e também sobre os processos de desfazer tal criança, desenvolvendo, assim, um entendimento específico sobre a categoria ex-criança soldado e sua formação.

Sob o prisma de Denov, as três imagens possuem importantes elementos em comum: "in each portrayal, child soldiers are exoticized, decontextualized and essentialized". (2010, p. 13). Alicerçando-me ao seu posicionamento, vejo a importância de questionar os extremismos de se pensar estas imagens ao reconhecer as ambiguidades e pluralidades que perpassam a experiências das (ex-) crianças soldado, seja antes, durante ou após o conflito. Isto é, ao invés de traçar um caminho temporal unidimensional que exclui as demais aberturas e histórias, os processos de ser e tornar-se devem ser norteados pela abrangência das múltiplas temporalidades, tanto do contexto, quanto das plurais percepções das crianças sobre o (pós-) conflito.

Enfim, penso que "the reliance on formulaic imagery reveals, above all, that we do not have a language to adequately represent the complexity of girls' and boys' involvement in armed conflict." (Denov, 2010, p.14). Por essa razão, neste momento, retomo e aprofundo as reflexões sobre a formação da categoria da excriança soldado para além do discurso do retorno, ressaltando a ambígua e, muitas vezes, paradoxal construção de seu status temporal em relação ao (pós-) conflito. Reconheço os caminhos tumultuados das estórias, busco perceber as complexidades dos momentos plurais das ex-crianças soldado e, para isso destino o meu escutar, junto com todas as suas limitações, aos seus dizeres. Seja agora seja mais adiante, as suas palavras vão tocando as minhas e, nas somas das letras, guardamos mais histórias.

Assim, o desfazer da criança soldado, como Denov (2010) denomina, envolve tanto os discursos do retorno para agora ex-criança soldado quanto a sua construção como categoria explicativa entre certos desenhos temporais difusos, de modo a 
transparecer os processos descompassados que acompanham o (des)contínuo (des)apego da criança com o grupo armado e também com o conflito. Ou seja, o relacionamento da (ex-) criança soldado com o (pós-) conflito revela-se como um processo não-linear e multidimensional, invadido pelas múltiplas temporalidades que cercam as experiências e eventos das narrativas plurais das crianças sobre o (pós-) conflito armado.

A fim de desafiar o entendimento linear e quase 'automático' sobre a reintegração social das ex-crianças soldado a partir da ruptura com o passado militar, pretendo mostrar algumas de suas falas, capazes de retratar a relação ambígua e plural entre a formação de sua categoria e o (pós-) conflito.

For a few years after the conflict ended, I was still living with the people who first captured me. The commander got a house for us to live in. The commander was living there with his three wives and the radio-man [communications person] from the bush. [Ex-menina soldado, Serra Leoa]. (Denov, 2010, p. 150).

Even when the war was over, I still saw myself as a soldier ... I certainly did not consider myself a civilian. [Ex-menino soldado, Serra Leoa]. (Denov, 2010, p. 151).

Sometimes others at school accuse me of being a militia and this makes me very sad - I had to stay with the militia. Sometimes I think people are talking about me and I feel very sad. I am afraid that the militia will come back here. We want to continue our studies but sometimes it is difficult - sometimes there are people who don't like us. I think the militia leaders should go before a tribunal. [Ex-menino soldado, recrutado aos dezesseis anos, Timor Leste]. (UNICEF, 2002, p. 69).

Essas (des)continuidades que marcam a relação entre a ex-criança soldado, o grupo armado e o (pós-) conflito mostram o quanto a configuração desejada para sua alocação temporal é problemática. Isto é, a fórmula do foi criança soldado é (ou, neste caso, espera-se que seja) criança resiliente (naturalizada e inocente) e será o adulto, que norteia as narrativas sobre o 'ex' da criança soldado, apresentam-se como incompatíveis em relação às ambíguas vivências dos eventos.

Neste sentido, o primeiro depoimento da ex-menina soldado de Serra Leoa nos mostra o quão difusas são as experiências de (des)ligamento do grupo armado, não se dando somente por rupturas e distanciamentos, capazes de deixar certas marcas, mesmo depois do conflito, como o exemplo da convivência diária ao longo dos processos de mudança. Essas marcas também se manifestam na própria percepção do "eu", como a segunda fala do ex-menino soldado demonstra, ressaltando a construção da identidade a partir das relações estabelecida com o 
grupo armado e sua (des)contínua movimentação nos processos de tornar-se. São temporalidades múltiplas que coexistem nas plurais trajetória das ex-crianças soldado.

A desconexão da criança soldado com seu grupo armado e a posterior obtenção do prefixo 'ex', portanto, são eventos cujos traços e laços, muitas vezes, permanecem nas entrelinhas das histórias e estórias das ex-crianças soldado e em sua percepção identitária. Por isso, com base no dizer do ex-menino soldado do Timor Leste, vejo como as vidas no pós-conflito, igualmente, manifestam-se de formas plurais e incertas, como se o medo tomasse até outras formas de estar por entre as relações sociais e como uma instabilidade marca o espaço/tempo do pósconflito. São mudanças graduais que mostram as mais variadas relações e linhas entre o passado, presente e futuro e suas temporalidades. Tempos em interrogação que traduzem incertezas em relação ao (pós-) conflito.

Em contraposição às ambíguas experiências das (ex-) crianças soldado, o discurso do retorno pela ruptura do passado militar parece afirmar que

[...] ultimately, for the second time in their lives, there was a necessity (and often a profound desire) to move from one world view to another - from a world of inhumanity, rigid hierarchies, detachment and cruelty to one based on principles of humanity, civic associations, empathy and caring. (Denov, 2010, p. 149).

Contudo, as plurais interconexões dos dois mundos - da infância moderna e do (pós-) conflito moderno - refletem a dificuldade em fixar finais e (re)começos demarcados, além de mostrarem as variadas permanências e continuidades das práticas do conflito nas vidas das (ex-) crianças soldado. Sendo assim, o meu objetivo por aqui não está em prover generalizações, mas sim, mostrar as heterogêneas vivências e experiências contadas pelas ex-crianças soldado que vão além dos discursos tradicionais, os quais as qualificam e as categorizam dentre uma linearidade temporal, principalmente, quando envolvidas no discurso sobre o trauma e a resiliência - discussão do próximo capítulo. Nessa perspectiva, a colocação do prefixo 'ex' se torna cada mais incerta e difusa ao longo dos caminhos temporais. 


\section{4 \\ Concluindo: os ventos do tempo}

Entre os fins e os (re)começos inexiste exatidão e simplificação. As linhas temporais das histórias e estórias das (ex-) crianças soldado se desenrolam de modo (des)contínuo e bagunçado, embaralhando as imagens que as qualificam e as temporalidades fixadas que as categorizam entre passado militar negativo e futuro do adulto estável. Desse modo, neste capítulo, busquei mostrar como a categoria da (ex-) criança soldado é construída por certos discursos limitados que nos permitem falar sobre determinados sujeitos, histórias e imagens como unos e homogêneos ao desenhar seus desvios e possibilidades para a realidade social. Ou seja, a (re)produção de sua categoria passa pelos discursos - construídos pela 'frouxa coalizão' - que acomodam os significados e entendimentos estruturados para a (ex-) criança soldado, para a infância moderna e para o conflito moderno que, igualmente, fixam um sentido temporal e conceitual para o prefixo 'ex' da excriança soldado.

Sendo assim, os desvios e as possibilidades modelados para as ex-crianças soldado se encontram encapsulados nos discursos da infância moderna ideal, em que a criança é projetada como vulnerável e incapaz de praticar ações violentas em conexão com os discursos do conflito moderno tido como bárbaro, caótico e sem objetivos/fronteiras definidos. Por isso, sua condição como (ex-) criança soldado a transpõe como um problema em necessidade de solução.

Outrossim, a condição desviante da ex-criança soldado vem quando ela é projetada como ameaça e risco para a ordem social e internacional devido a sua difusa e incerta posição no presente. A pergunta que guia sua ocupação temporal é orientada para o futuro em menção ao seu passado militar: será a ex-criança soldado capaz de superar seu passado traumático e de se envolver no ambiente civil de modo desejado como sujeito adulto? Entre o passado e o futuro, o presente se torna um ato de espera, um tempo apertado entre esquecimentos e superação, redefinindo a concepção temporal e os tempos verbais capazes de serem conjugados para a excriança soldado junto a suas histórias.

As possibilidades de seu entendimento como categoria englobam tanto o reconhecimento de sua condição desviante, quanto seu enquadramento na narrativa da constante vitimização e não-responsabilização do ser criança, cuja proposta tenta 
retomar os discursos da infância moderna ocidental da criança, essencialmente, inocente para a agora ex-criança soldado em busca de redenção. Sob esse prisma, as histórias possíveis de serem contadas são as que se encaixam nos discursos sobre o sujeito traumático e/ou sobre a resiliência (ser resiliente), narrando os eventos do (pós-) conflito e das experiências das ex-crianças soldado em meio ao discurso do retorno.

Em razão do exposto, no próximo capítulo, pretendo me engajar nas reflexões sobre ambíguas relações entre os discursos do trauma e os da resiliência desenhados para a categoria ex-criança soldado, mostrando o quão complexas são suas interconexões. $\mathrm{Na}$ análise temporal, a produção dos eventos - sejam de rupturas sejam de (des)continuidade entre a criança e o (pós-) conflito - reflete a impossibilidade de o sujeito da ex-criança soldado se situar em um passado militar específico, configurando uma relação temporal linear entre a sua categoria e os discursos do trauma e da resiliência. 


\section{3 \\ Passado e futuro: os discursos do tratamento do trauma e da resiliência para a ex-criança soldado}

\section{1 Introdução}

Falar sobre o tempo é temperar pluralidades, frisar historicidades e perceber outros mundos em nós mesmos, por isso, estabelecer um caminho específico para estes tempos ganharem sentido é simplificar encontros e histórias sobre as múltiplas temporalidades que coexistem em um evento.

A categoria da ex-criança soldado moldada por entre os discursos do trauma e da resiliência ganha corpo analítico e explicativo no passo de suas alocações temporais, o que nos possibilita ajeitar o que é ser criança em antes e/ou depois. Por essa razão, seja através da produção dos desvios e possibilidades para as ex-crianças soldado seja pelo agrupamento de suas imagens na lógica dos extremos, a sua categoria no presente me parece articulada junto a uma ideia de espera que orbita por entre determinadas relações sociais através de interrogações e incertezas. O passado e futuro, nesta sua posição, dizem mais sobre seu existir do que, propriamente, sua posição no presente.

As possibilidades de ser no presente se encontram, paradoxalmente, inscritas no prefixo temporal do 'ex'. Desse modo, como apontei antes, o 'ex', como prefixo temporal, não somente traz o passado da criança soldado, mas também quase 'automaticamente' mexe com o futuro do adulto que está por vir. Nesses discursos, esses dois tempos se tornam dois mundos bem delimitados em posições binárias: no passado militar, coloca-se a possibilidade de se projetar o evento traumático e no futuro, as histórias de superações do ser resiliente.

As relações que são estabelecidas entre essas duas realidades mantêm seus entendimentos em planos e tempos separados; os discursos do trauma e da resiliência para a ex-criança soldado, portanto, parecem disputar e, ao mesmo tempo, simplificar um entendimento específico para sua categoria, principalmente, em relação ao lugar do seu passado militar e do seu futuro adulto. Contudo, o que pretendo mostrar aqui são as complicadas interconexões entre o os discursos do trauma e da resiliência, plurais por si só, e dos “entres" temporais, ou melhor, das temporalidades que entram em cena pluralizando o que nunca é/foi singular. 
Sendo assim, vou modelando uma análise crítica do tempo, tentando problematizar a concepção da linear construção entre o passado, o presente e o futuro ao mostrar as múltiplas e ambíguas relações entre os discursos do trauma e da resiliência para a ex-criança soldado as quais transbordam e deturpam as fronteiras temporais fixadas. Além disso, a incômoda posição temporal da excriança soldado, igualmente, mostra-se capaz de colocar em dúvida as adjetivações dadas às suas memórias e planos ora como traumatizadas ora como resilientes.

Neste sentido, de primeiro momento, busco (re)produzir o argumento sobre o lugar do passado militar na vida das ex-crianças soldado pela referência do 'estar traumatizadas', mostrando como a possibilidade dos discursos do trauma vem aliciada ao suposto poder de generalizar as experiências das (ex-) crianças soldado sobre o conflito em um mesma história. $\mathrm{O}$ único efeito negativo do envolvimento no grupo armado dado pelos discursos dos tratamentos de trauma, portanto, demanda um passado militar a ser (re)configurado a fim de ser compreendido, o que me permite falar sobre certos esquecimentos necessários para a superação e, consequentemente, para a 'cura' dessas crianças. (Guyot-Diangone, 2012). Tais generalizações das experiências e memórias das ex-crianças soldado contribuem para a fixação de um tratamento direcionado capaz de alocar o passado militar no singular e conceder-lhe um entendimento de "tempo perdido", ou melhor, quando colocado junto ao discurso da infância moderna: de "infância perdida".

De outro lado, os discursos das ex-crianças soldado como resilientes se posicionam em um local diferente daquele ocupado pelo trauma, ou seja, o paradigma da resiliência enfatiza a capacidade de adaptação e superação da criança perante uma situação adversa, como exemplo, o seu envolvimento com o grupo armado. Em virtude disso, ao invés de encará-las como traumatizadas e congeladas pelas feridas do conflito, $o$ 'ser resiliente' frisa a capacidade das ex-crianças soldado de lidarem com seu passado militar de modo a (re)configurar em a sua olhada para o futuro, para a estabilidade do mundo adulto. Esta noção do 'ser resiliente' dialoga com a imagem do herói redimido, apresentada por Denov (2010), para a ex-criança soldado que é capaz de, mesmo após uma situação de extrema dificuldade, superála e ficar bem. O maior potencial da criança de ser resiliente em comparação ao adulto, por entre estes discursos, ganha base explicativa quando juntado aos conhecimentos do desenvolvimento infantil e às teorias de socialização que frisam a maleabilidade do ser criança na construção e reconstrução de sua identidade. 
Nesta perspectiva, aqui analiso três documentos de estilos e escritas diferentes sendo, ao mesmo tempo, igualmente capazes de construir um entendimento temporal e subjetivo específico para a categoria ex-criança soldado por entre as linhas do ser resiliente - as quais estão em constante relação aos discursos do trauma. Os textos são: Handbook of Resilience in Children of War (2013), elaborado por Chandi Fernando e Michel Ferrari; o manual para fins humanitários utilizado também pela UNICEF - Iasc Guidelines on Mental Health and Psychosocial Support in Emergency Settings (2007); e a história autobiográfica de Ishmael Beah "Muito longe de casa: memórias de um menino-soldado", lançado em 2006. Esses textos traduzem, cada um a seu modo, as tentativas de estabelecer um significado para a categoria ex-criança soldado e sua alocação temporal, deslizando por um passado militar e um futuro adulto.

O que pretendo mostrar, nesta parte, entretanto, são as confusas e ambíguas relações e negociações entre os discursos do trauma e da resiliência para a excriança soldado que vão além da já estabelecida colocação opositora, não sendo possível simplificar a posição temporal do ser ex-criança soldado e nem generalizar o sujeito por trás de sua categoria. Pois, tanto os discursos das ex-crianças soldado como traumatizas quanto os outros que as colocam como resilientes, por mais que almejem estabilizar qualidades diferentes, expressam as rupturas e (des)continuidades de se pensar a condição temporal da ex-criança soldado, por meio do desenho de um determinado passado militar traumático e de um futuro do adulto resiliente. São condições sempre em disputa e (des)continuidades, assim como as plurais histórias e estórias das ex-crianças soldado.

Destarte, através de deslocamentos, repetições e sobreposições, a relação entre os discursos da resiliência e do trauma para a ex-criança soldado refletem histórias e estórias de falhas, caos, fragmentos e heterogeneidade ainda que os interesses dominantes, apoiadores da História em maiúscula (no singular), busquem estabelecer e manter a estabilidade de uma certa relação entre as (ex-) crianças soldado e o (pós-) conflito. Relação esta que desenha uma determinada posição temporal para o ser ex-criança soldado, capaz de organizar suas vivências no jogo do trauma e da resiliência através de específicas qualidades e entendimentos. Ademais, o discurso da infância moderna colabora com a elaboração de ideais de superação para as ex-crianças soldado, acomodando-as em tempos e posições passíveis de tradução em relação ao ser criança. 


\section{2 \\ Ex-crianças soldado como traumatizadas}

O discurso do retorno para a (ex-) criança soldado, no âmbito do impacto individual, articula certas possibilidades de pensar como o efeito do passado militar pode ou deve ser compreendido não somente pela criança, mas, principalmente, pela sociedade adulta. Sendo assim, nesta parte, busco mostrar, a partir da concepção do trauma para a ex-criança soldado ou do 'estar traumatizadas', como a sua categoria ganha um espaço discursivo nos movimentos de suas memórias, entre quais são ou não permitidas. Os discursos do trauma para a ex-criança soldado afirmam que o envolvimento da criança no grupo armado é um fato, essencialmente, negativo, cujo desfazer deverá ocorrer por meio de tratamentos clínicos - como terapias individuais, por exemplo -, destacando a importância das práticas médicas para a 'cura' dessas crianças. (Guyot-Diangone, 2012).

De acordo com esta configuração negativa do passado militar, o sujeito excriança soldado traumatizado é colocado em voz passiva, em uma posição de enfermidade, vulnerabilidade e vítima, sendo incapaz de ser e saber por si só. Watson (2015) aponta que esta condição de 'vítima'-identificada como uma pessoa ferida, injuriada ou morta em resultado de um crime, acidente ou outro evento e ação - (re)produz a concepção ocidental de vitimização como anulação da agência e da racionalidade do indivíduo que sobrevive após uma situação de risco. Acredito que esta imagem de vítima em que a (ex-) criança soldado é articulada está em sintonia com o próprio discurso da infância moderna (ocidentalizada) e de suas temporalidades, que destacam a inocência e vulnerabilidade naturalizada do ser criança no presente.

A descrição básica da vítima é sua passividade, seu nome é suspenso nas notícias midiáticas e nos discursos políticos, e seu desespero é o alvo de comoção geral: "many are women and children twice victimized because of their gender and age”. (Mutua, 2001, p. 229). A vitimização está associada, nestes termos, ao chamado para intervenção e 'salvamento', principalmente, quando imagens de crianças soldado (por exemplo) são propagadas nos noticiários com o objetivo de destacar a urgente necessidade de "se fazer algo sobre isso". Isto é, já partindo do pressuposto de que a vítima se encontra em um estado de incapacidade e 
irracionalidade para decidir e tomar decisões, a condução de um tratamento vem de iniciativa alheia (posicionada na parte adulta racionalizada), sendo a conotação primária do ser vítima ligada à ideia de compaixão e miséria compartilhada.

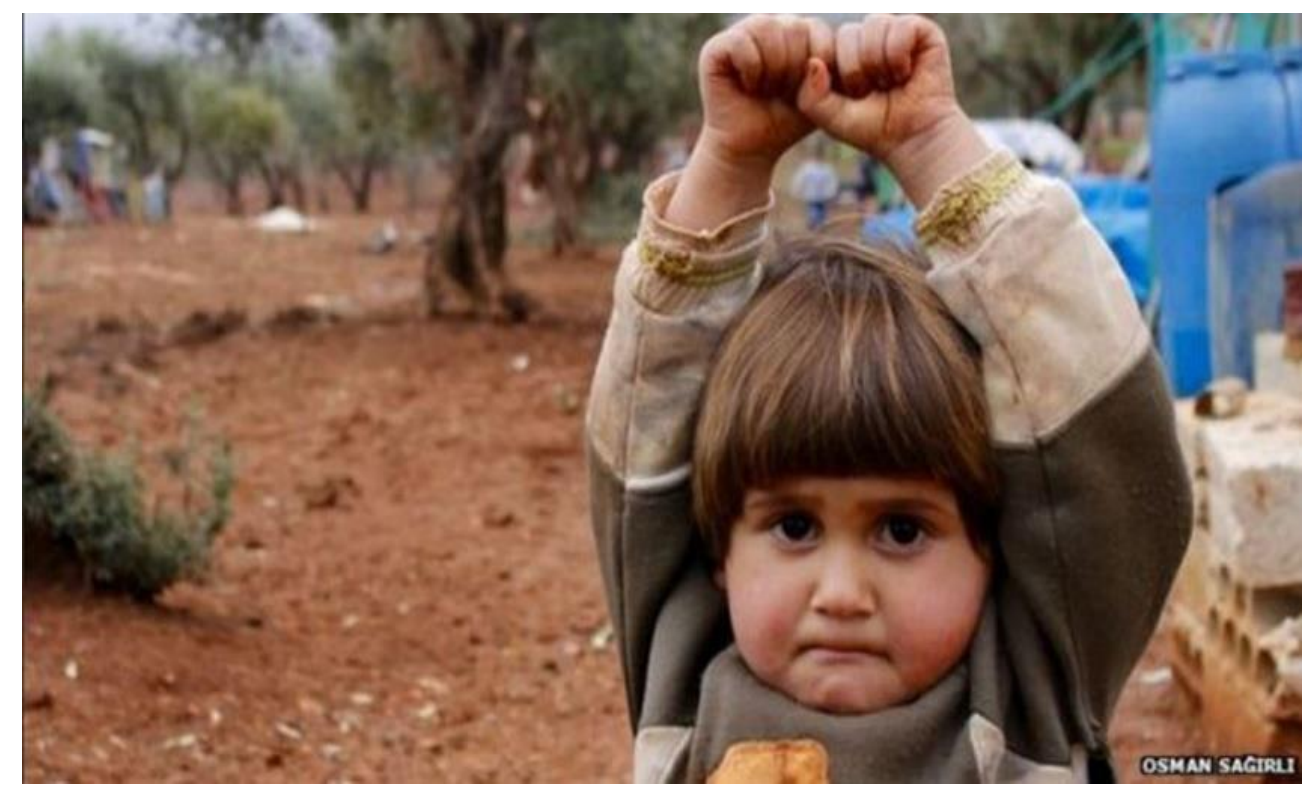

Figura 3: Criança síria fotografada por Osman Sagirli, 2012.

Esta foto da criança síria rendida perante a câmera me faz pensar na (re)produção de um ideal de vítima infantil, inocente que, ao invés de carregar uma arma, rende-se a uma. Portanto, a história desta criança síria no campo de refugiados que se rendeu perante uma máquina fotográfica, ao pensar ser uma arma de fogo, transpõe imagens de passividade e pureza que harmonizam com o imaginário da criança moderna no presente, essencialmente, inocente como a vítima infantil ideal do conflito.

Sob outro aspecto, se para trazer o entendimento imediato da criança soldado em uma foto, é necessário dispor de mecanismos estéticos específicos como, principalmente, a presença de uma arma de fogo (por mais que criança soldado não seja somente a criança combatente), a sua relação com o status de vítima transparece muita ambiguidade em um clique. O relacionamento da criança com uma arma de fogo de verdade movimenta concepções de desordem, caos e incompatibilidade, porquanto, de certa forma, a arma concede à criança o poder de decidir sobre matar e/ou ferir alguém e esta certa condição de 'agenciamento' contradiz a passividade inscrita no papel de vítima e também da criança no singular. 
Por conta disso, penso que a projeção da vítima infantil ideal, retratada como passiva, vulnerável e digna de compaixão, encontra-se mais bem acomodada quando o prefixo 'ex' é colocado na criança soldado e seu passado militar representado, esteticamente, pela arma de fogo - é traduzido agora pelos discursos do trauma. A pose de vítima para a (ex-) criança soldado, assim, estabelece certas temporalidades e entendimentos para as categorias que, idealmente, oscilam entre a presença de medo em tons passivos. A prerrogativa da arma de fogo nas mãos da criança no presente traduz sentimentos de desamparo e de "inversão de valores", e seu medo atua de maneira ativa nas entrelinhas dos discursos de 'salvamento' e 'intervenção'.

Outrossim, trazendo, no presente, a imagem da criança soldado como selvagem, irracional e descontrolada, os discursos do tratamento do trauma buscam também promover, a partir de práticas médicas, soluções para a contenção da agressividade e para o controle emocional e corporal da agora ex-criança soldado passível de ajuda e tratamento, com o intuito de prover a ordem e estabilização. Dessa forma, além da figura de 'vítima', os discursos do trauma para a categoria (ex-) criança soldado, igualmente, mobilizam a sua imagem como selvagem em necessidade de intervenção e controle adulto.

Ainda, dentro dos discursos do trauma, quando o envolvimento militar da criança é conjugado no passado, a categoria ex-criança soldado consegue ser construída em voz passiva e ser traduzida como potencial para a mudança (a partir de tratamentos específicos), atuando como, principalmente, vítima. Portanto, alinho-me à posição de Van Dijk (2009), quando este assevera que

the issue under investigation is not, for example, to what extent victims suffer from neatly described mental disorders such as post traumatic stress syndromes. The issue is whether focussing on such disorders when describing those affected by crime is objectively justified or reflects a hidden bias resulting from the labelling of such persons as victims. (p.8).

Procuro, então, questionar e bagunçar esta associação objetiva e naturalizada produzida entre o 'estar traumatizada' e a vitimização das ex-crianças soldado, destacando que estes discursos sobre o lugar e tempo do trauma movimentam decisões políticas (dentro do mundo adulto) sobre quais comportamentos e histórias são esperadas do sujeito infantil e quais são silenciadas ou postas entres aspas. 


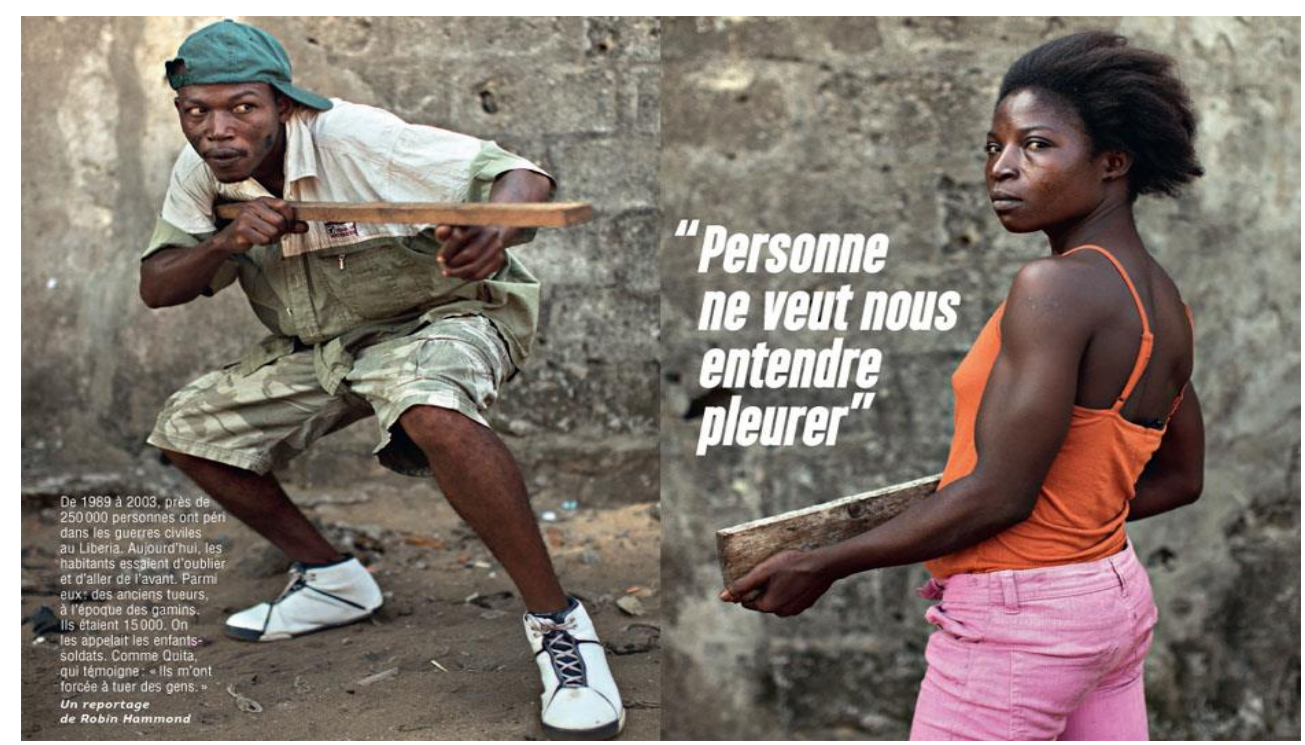

Figura 4: Ex-crianças soldado da Libéria. Foto da Polka Magazine, 2013.

Como trazer, esteticamente, a ex-criança soldado no presente? Como construir o entendimento de sua categoria em um clique? Penso que essas imagens buscam dinamizar as representações do prefixo temporal 'ex' da ex-criança soldado no presente, substituindo a arma de fogo - que, um dia, formara o entendimento da criança soldado - por uma tábua de madeira como símbolo de mudança social sendo relacionada aos programas de treinamento vocacional, como carpintaria, por exemplo, presentes nos processos de reintegração social. As posições de ataque, similares àquelas projetadas para o uso de armas, já não mais causam medo, uma vez que estão inseridas em um outro jogo temporal, quando o envolvimento militar está colocado no passado, no tempo tido como acabado.

Logo, o afastamento desejado entre o mundo da infância moderna e o do conflito armado moderno (re)conduz ao prefixo 'ex' um retorno à passividade $\mathrm{e}$ vulnerabilidade da criança que deixou para trás a arma de fogo e agora busca se (re)estabelecer à ordem social. Uma mobilização capaz de construir a possibilidade de se pensar a ex-criança soldado como, de certo modo, retornando a um status de vítima infantil ideal. Por esse motivo, o passado militar é projetado como, essencialmente, negativo ao ajeitar a ex-criança soldado no discurso do retorno como 'vítima' traumatizada em necessidade de tratamento e de condução especial adulta a fim de retornarem ao meio social de maneira 'satisfatória'.

Com este enfoque, pretendo desenvolver aqui como a concepção, essencialmente, negativa do passado militar (re)produz um entendimento específico do envolvimento da criança no grupo armado e também de sua saída, além de 
moldar quais palavras entram em destaque e quais são colocadas de lado. O 'estar traumatizada' como condição primária e quase imediata de conhecimento da categoria ex-criança soldado configura o seu status de vítima e fixa um de seus desenhos temporais construídos juntos ao prefixo 'ex' sobre a permanência de um passado militar. O que, paradoxalmente, expressa as impossibilidades de generalizar as ambíguas rupturas e, ao mesmo tempo, as continuidades que tentam conjugar o passado militar no singular.

\subsection{1}

\section{O passado militar: o envolvimento no singular}

O passado militar que marca o prefixo temporal 'ex' da categoria ex-criança soldado coloca a história do envolvimento da criança no grupo armado em verbos do pretérito, ou seja, a vida do ser criança soldado, embora continue sendo narrada em voz passiva, agora é conjugada em verbos do passado, no tempo que já se fora. Os discursos da ex-criança soldado como traumatizada transpõem certos dizeres sobre o tempo das memórias deste passado e de quais histórias conseguem (co)existir com a noção moderna e ocidentalizada acerca da guerra, da infância e da combinação destas duas.

Sendo assim, é dentro do discurso do retorno que os processos de reintegração social para as ex-crianças soldado destacam a primazia e, basicamente, indispensabilidade da reunificação familiar, da frequência escolar e do apoio psicossocial para uma bem-sucedida volta destas crianças ao ambiente social. Os Princípios de Paris de 2007, além de modificarem o termo criança soldado para criança associada a uma força armada ou grupo armado no intuito de abraçar sua abrangência definidora, igualmente, substituiu os programas de DDR destinados às ex-crianças soldado para os chamados processos de Liberação e Reintegração. Esta modificação veio com vistas a relacionar, mais propriamente, a realidade das crianças atuantes no conflito armado, dadas as dificuldades dos programas de DDR em reconhecer as necessidades específicas de sua categoria. (UNICEF, 2007).

Os programas de Liberação e Reintegração, do mesmo modo que as práticas do DDR, continuam realçando o papel da família e da educação como dois componentes básicos para a bem-sucedida reintegração social das ex-crianças soldado, além de frisarem, na maioria de suas práticas, a importância dos suportes 
psicossociais para o próspero e estável retorno à vida civil e ao desenvolvimento das crianças em adultos 'saudáveis'. Neste sentido, "the transition of the child from a military environment and the first step towards reintegration into civilian life begins with their release from armed forces or armed groups". (UNICEF, 2007, p. 27).

Conforme já discutido no capítulo segundo, as relações plurais e desiguais entre a formação da categoria ex-criança soldado e o (pós-) conflito se apresentam de inúmeras formas em suas histórias e estórias, por isso, vejo que o tom passivo do termo liberação camufla as outras maneiras em que o prefixo 'ex' é colocado no texto. Ou seja, o desligamento formal ou saída da criança soldado do grupo armado pode ocorrer por meio tanto de fuga, saída voluntária, quanto da liberação - a partir de negociações com a equipe da UNICEF junto aos grupos armados ou por dispensa concedida diretamente pelos mesmos.

Essas outras maneiras de colocar o envolvimento militar no passado bagunçam com um discurso de passividade e vitimização da (ex-) criança soldado como não capaz de tomar as decisões que marcam sua trajetória, devendo, assim, ser guiada por outros. As histórias que ganham espaços são aquelas que a colocam, constantemente, em posições de vulnerabilidade e insegurança com necessidade de proteção e cuidado. Além disso, por mais que os programas de Liberação e Reintegração procurem questionar o olhar do trauma para as ex-crianças soldado, a partir dos discursos da resiliência, os processos que tomam destaque após a liberação dessas crianças se mantêm em consonância com os discursos da infância moderna e suas temporalidades. Parafraseando: continuam articulando a necessidade da família, da educação e de suas temporalidades na vida das excriança soldado e, da mesma forma, desenham o passado militar como tempo a ser superado com a finalidade de traduzir a condição incerta de sua categoria para o internacional.

Sob esse prisma, depois dos processos de liberação, as ex-crianças soldado são, primeiramente, encaminhadas aos chamados centros transitórios e ali permanecem por não mais que três meses, idealmente. Este processo é guiado e planejado pela UNICEF, geralmente, com ajuda de alguma ONG parceira, com a intenção de separar essas crianças da vida militar e, em alguns casos, do próprio conflito que continua se desenrolando lá fora. As atividades dentro dos centros são projetadas na base da proteção e cuidado das crianças, envolvendo a localização e 
reunificação familiar, relação com a comunidade, educação e/ou emprego, junto com a constante ênfase aos apoios psicossociais. O passado do envolvimento militar carrega em si o desvio do passado infantil, desejável para o ser criança, já possuindo uma carga negativa e corruptiva em relação ao desenvolvimento infantil e à saúde mental da criança.

O passado do envolvimento militar se apresenta unificado em um evento negativado, enquanto, em contrapartida, o passado 'positivo' se encontra em um momento idealizado, talvez antes das memórias do grupo armado quando a criança estava em consonância com $a$ criança moderna: era amada pela sua família, frequentava a escola do bairro e brincava com seus amigos. O passado militar, neste sentido, mesclado com as experiências violentas do conflito, veio sem ser chamado, como um pesadelo na madrugada, tal qual o 'outro' sombrio, capaz de romper com o caminho natural do ser criança. Essa narrativa de ruptura produz e uniformiza o evento traumático da vida das (ex-) crianças soldado, essencialmente, no passado do seu envolvimento militar; sendo que qualquer tipo de estabilidade mental e emocional se encontra, assim, intimamente ligada à superação e (re)configuração deste passado militar.

Os discursos do tratamento do trauma para ex-criança soldado são pautados, portanto, nestes momentos de rupturas: a da criança para a criança soldado e a da criança soldado para a ex-criança soldado, eventos construídos como instáveis, que desestabilizam e perturbam a saúde mental das crianças. Quando pensamos nas excrianças soldado, o passado do envolvimento militar é tratado como um contínuo traumático, como um evento no singular, isto é, desde o passo de entrada da criança no grupo armado até seu passo de saída, tudo parece igualado em um único momento, cronologicamente quantificado e já negativo por si só. Sendo assim, por mesmo que as motivações e experiências das (ex-) crianças soldado sejam plurais dentro do grupo armado, a sua estada lá já resulta em um evento traumático único e desviante da concepção ideal do ser criança e da forma de se pensar um passado infantil.

Contudo, as construções do passado do envolvimento militar como negativo e do passado da infância naturalizada como positivo escondem muitas outras histórias que, possivelmente, desordenariam esta noção singular dos dois passados projetados na vida da ex-criança soldado entre positivo/negativo ou 
normal/desviante. Estas duas experiências das ex-meninas soldado, narradas a seguir, traduzem o exposto:

When my mom arrived, she gave me a beating, wow, she beat me, it was a shame. I mean, she hit me really hard; I mean she treated me really badly.And that was when I, I started seeing those people more. I met some friends there, I used to talk to them, and so they asked me to join the guerrillas. [Ex-menina soldado, Colômbia]. (Brett; Specht, 2004, p. 88).

Home life was difficult. My father [stepfather, in fact] was a heavy drinker, he didn't work. He drank and then he struck us all. [Silence] Mom often went to the fields, she left us with him, and he drank and struck us. [Silence] When he drank a lot, he did as if I was his wife. [. . .] I left because he beat us, he drank, and then he took me as his wife. I preferred to die in the war rather than to stay at home and to keep on suffering. [Ex-menina soldado, República Democrática do Congo]. (Brett; Specht, 2004, p. 88).

Nesse sentido, existem muitas idas e vindas que perpassam as construções e negociações das histórias dos passados das ex-crianças soldado e das reproduções dos momentos de rupturas e (des)continuidades que não devem ser mantidas no singular. As múltiplas temporalidades que se conjuram na imensidão das memórias e experiências dessas crianças são mascaradas na fixação de uma divisão temporal linear, silenciando os dizeres plurais e ambíguos que as formam como categoria temporal. O exemplo das experiências das ex-meninas soldado nos aponta para a plural relação entre a construção dos passados, sendo impossível delimitar momentos específicos de rupturas entre uma dada normalidade e o desvio e de estabelecer direcionamentos, essencialmente, binários entre o passado infantil desejável e o passado militar desviante.

A percepção do abuso doméstico que marca essas duas histórias conta algo diferente, sendo capaz de trazer outras vivências sobre a relação da criança com o grupo armado além daquela construída como, essencialmente, corruptiva e negativa. Por isso, “ it is an oversimplification to lump all former child soldiers together in the single category ' traumatized children', implying that they have all been affected similarly or require similar supports". (Wessells, 2006, p. 128).

Entrando mais especificamente nos discursos sobre o tratamento do trauma para a ex-criança soldado, percebo que suas bases de análise dependem da natureza e cronicidade das experiências da criança na guerra, visto que, quanto mais duradoura for a permanência da criança dentro do grupo armado e quanto mais intensa for a natureza dos eventos lá vividos, maiores são as chances de elas 
desenvolverem enfermidades psicológicas e emocionais ao ir acumulando mais experiências estressantes. (Wessells, 2006).

Dominated by medical and psychological perspectives, studies of war-affected children normally focus on adverse impacts at the individual level, correlating exposure to violence, separation, and other stressful events with the number killed, injured, disabled, "traumatized," and so on. The psychological research in particular tends to employ a pathological framework, positing a direct and rather mechanical relation between exposure to violent events and impaired mental health or social functioning in the young (Boyden, 2003, p. 352).

O trauma, portanto, é representado pela literatura médica e psiquiátrica como uma ferida da mente, ao contrário das feridas do corpo, a da mente causa uma ruptura com a noção de tempo, da percepção do "eu" e do mundo. (Caruth, 1996, p. 4). Mais precisamente, o entendimento do trauma está na relação de produção de um fator estressante, definido como traumático quando ameaça a vida do indivíduo ou sua integridade física e provoca uma resposta subjetiva de medo e desamparo.

(Klasen et al., 2010). As ex-crianças soldado traumatizadas são projetadas como 'enfermas' e, por consequência, dependentes de tratamentos (as enfermidades e as curas entram no vocabulário médico) que visam à superação deste estágio de perturbação, causado pela violência de seu passado militar no singular, essencialmente, negativo.

Sempre que eu abria a torneira, em vez de água tudo que eu conseguia ver era um jato de sangue. Eu olhava aquilo fixamente até que parecesse água outra vez, antes de beber ou tomar banho. Às vezes passavam garotos correndo pelo corredor gritando: "os rebeldes estão vindo! ". Ou então os garotos mais novinhos sentavam ao lado de algumas pedras e choravam, dizendo que as pedras eram seus familiares mortos. E havia ainda surtos em que fazíamos emboscadas para o pessoal da equipe [da UNICEF], amarrávamos e interrogávamos todos sobre a localização de seus pelotões, onde conseguiam seus suprimentos de armas e munição, drogas e comida. (Beah, 2015, p. 160).

Embasando-se nesses tipos de atitudes descritas acimas, uma grande parte dos estudos nos campos da psiquiatria, psicanálise e neurobiologia insistem nos efeitos diretos da violência externa na desordem psíquica, focando, principalmente, na prevalência do distúrbio do estresse pós-traumático nas ex-crianças soldado. $\mathrm{O}$ PTSD é entendido como uma resposta incontrolável aos eventos súbitos e catastróficos que ocorrem, geralmente, a partir de repetitivas aparições de alucinações e outros fenômenos intrusivos. (Caruth, 1996, p. 57), como repetitivas 
memórias do evento traumático, medos relacionados ao trauma, comportamentos repetitivos, etc. (Klasen et al., 2010). A fala de Beah sobre suas experiências dentro do centro de reabilitação mostra como esta resposta entra em cena ao produzir certos efeitos incontroláveis e imprevisíveis, cujo retorno ao ambiente militar marca a possibilidade de o passado estar presente.

De outro lado, acredito que este diagnóstico

became a way of managing traumatic memory, rendering it pathological and subject to cure, and demanding that those diagnosed with the disorder seek the assistance of therapeutic interventions in order to govern their interior lives, and their behavior. (Howell, 2012, p. 216).

A (re)produção deste diagnóstico se tornou algo recorrente por entre os discursos de intervenções humanitárias, o que possibilitou, por exemplo, a existência de um estudo sobre estresse traumático em Serra Leoa, cujo resultado mostrou que $99 \%$ da população do país possuía o distúrbio por conta do conflito. Este estudo, conduzido pelos Médicos Sem Fronteiras e publicado pelo The Lancet em 2000, foi realizado em Freetown (Serra Leoa), após um período de intensa violência em janeiro de 1999, e agrupou uma quantidade de 245 indivíduos escolhidos ao acaso para participarem da pesquisa por meio de entrevistas e questionários.

A capacidade de categorizar uma população inteira como enferma ao diagnosticá-la com PTSD pela coleta seletiva de dados de apenas 245 serra leoneses mostra o quão 'naturalizado' este distúrbio se apresenta em ambientes de pósconflito, além da possibilidade de alocar todos os nacionais como vítimas em posição de vulnerabilidade e passividade, em necessidade de tratamentos vindos de fora.

Em relação às ex-crianças soldado, as metodologias de análise para identificar PTSD seguem, igualmente, um caminho baseado em procedimentos individuais como entrevistas e preenchimento de questionários (ver Figura 5) e, do mesmo modo, os certos tratamentos já são pré-estabelecidos nos discursos como a forma mais correta para suas reabilitações sociais. Além disso, percebo que a maioria dos estudos disponíveis sobre o caso clínico das ex-crianças soldado foram conduzidos, principalmente, em países africanos com ex-crianças soldado africanas, o que acaba homogeneizando e localizando a (re)produção da categoria nas experiências deste 
específico continente. Fato que esconde e silencia a pluralidade e abrangência do envolvimento militar da criança e de suas relações com o (pós-) conflito e acaba reforçando a distância construída entre a infância moderna ocidentalizada e o conflito armado moderno não-ocidental.

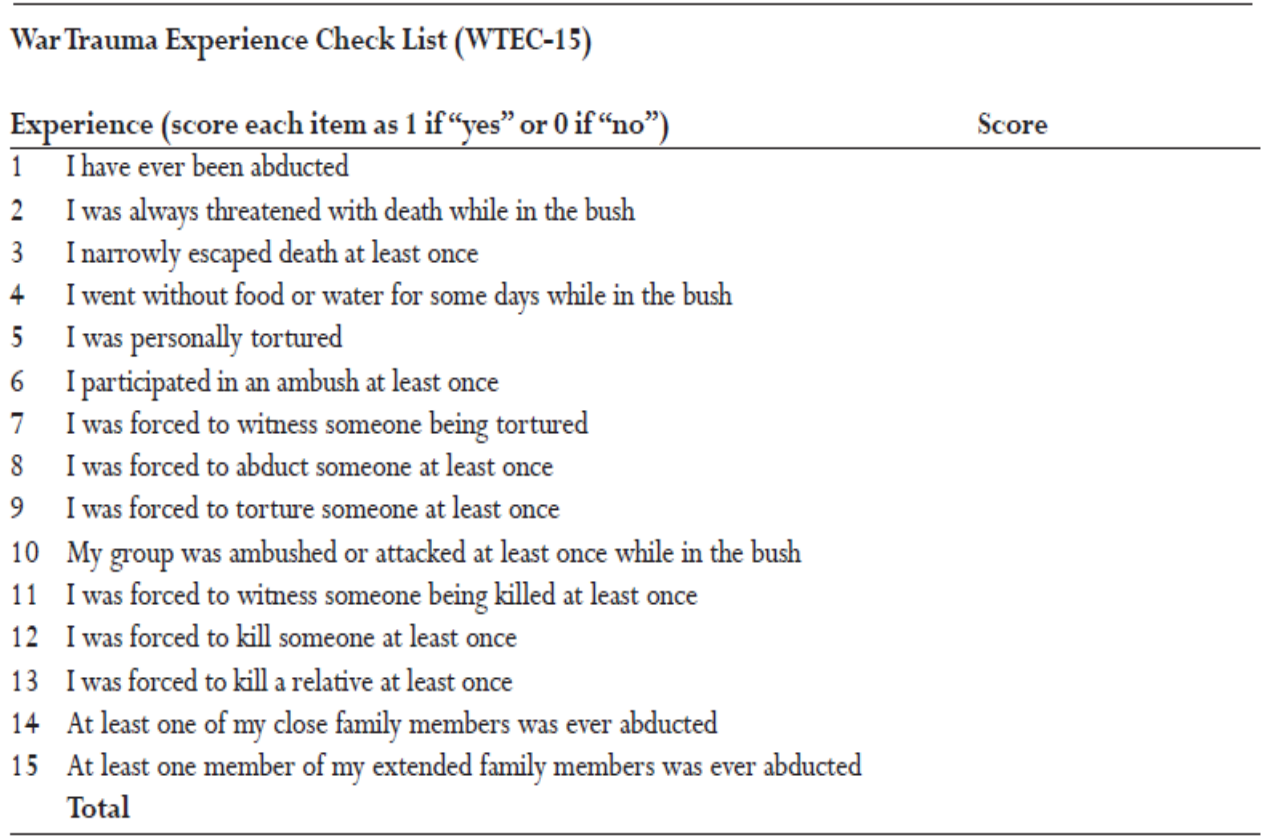

Figura 5: Exemplo de questionário sobre trauma destinado às ex-crianças soldado ${ }^{19}$

Governados por perspectivas médicas e empiristas no campo da Psicologia, Psiquiatria e Neurobiologia, os discursos do trauma e da resiliência para a excriança soldado, portanto, organizam as quantidades em categorias, os resultados em diagnósticos capazes de enquadrá-la entre traumatizada e resiliente. Neste sentido, como exemplo, cito um estudo clínico realizado em Uganda com 102 excrianças soldado, dentro de uma escola primária de reabilitação social, que seguiu a hospitalização de 12 destas crianças na ala psiquiátrica do Hospital Regional Referencial de Gulu em novembro de 2006. (Ovuga et al., 2008). De acordo com as respostas do questionário acima, foi visto que $87,3 \%$ das crianças presenciaram dez ou mais eventos traumáticos, sendo que, junto com outros dados dos demais questionários, os pesquisadores concluíram que a maioria destas crianças sofrem com transtornos psicológicos por conta da guerra, ou seja,

\footnotetext{
${ }^{19}$ Figura disponível no texto: Ovuga et al. Post-traumatic stress disorder among former child soldiers attending a rehabilitative service and primary school education in northern Uganda. African Health Sciences, v. 8, n. 3, p. 136-41, 2008.
} 
it soon became clear that nearly every child suffered from some form of war-related psychological disorder, which was subsequently evidenced by $88 \%$ of the children having screened positive for depressed mood [...] and (55.9\%) of the children having screened positive for post-traumatic stress disorder. (Ovuga et al., 2008, p. 140).

Assim, percebo que os discursos do trauma para a ex-criança soldado tendem a colocá-la em voz passiva, sendo capazes de adequar um adjetivo para sua categoria e um entendimento para o seu passado militar, essencialmente negativo, discursos esses traduzidos por entre esquecimentos e superação. Devido a isso, vejo que a projeção do trauma para a ex-criança soldado gira em torno de dois pontos que me parecem centrais: 1) a capacidade de alocar o evento traumático única e automaticamente no passado militar; 2) o reconhecimento de que a 'cura' para essas crianças viria por meio de certos esquecimentos capazes de bloquear o retorno das memórias traumáticas e incontroláveis no presente.

Tendo em vistas esses aspectos, localizar o trauma no passado do envolvimento militar é padronizar as múltiplas e ambíguas experiências das excrianças soldado em um mesmo diagnóstico, além de apresentar uma única história sobre a (ex-) criança soldado e sua alocação temporal. Essa visão, essencialmente negativa do passado militar, caracteriza-o como "tempo perdido", passível de ser marginalizado e/ou amenizado por entre os discursos da ex-criança soldado como traumatizada, podendo aparecer somente quando elas são qualificadas como resilientes e buscam afirmam uma certa "lição de vida". Isto é, o sujeito narrador e o modo como se conta uma história de superação devem estar em sintonia com o sentido de seu prefixo 'ex', no qual o passado militar é projetado como superável pela esperança da promoção de um adulto racional, saudável e estável emocionalmente.

A "infância perdida" das ex-crianças soldado lembra um passado que deveria existir, um caminho que deveria ser, mas não o foi. O passado militar se assemelha a uma marca suja, uma dor profunda que usurpa o ser no presente. Portanto, a referência negativa do passado do envolvimento militar se constrói em relação a um idealizado passado infantil pautado nas entrelinhas da criança inocente e vulnerável. Por isso, o discurso do retorno ganha base nas possibilidades de projetar eventos desejáveis sob os discursos da infância moderna. 


\section{3 Ex-crianças soldado como resilientes}

É no ritmo de presenciar o presente na espera do existir que minha análise mostra os arredores das temporalidades destinadas à categoria ex-criança soldado, sendo também através de meus próprios escritos que seus sujeitos, paradoxalmente, adquirem histórias e estórias. O movimento das temporalidades para as ex-crianças soldado passa por entre a produção de determinados eventos: pelo passado militar, época da violência do conflito, junto com o futuro da salvação e superação do sujeito resiliente. Entretanto, a alocação temporal da ex-criança soldado, traduzida como traumatizada e/ou resiliente, mobiliza, outrossim, relações e permissões a partir da possibilidade de categorizar o sujeito e fixar seus desvios e qualidades em uma determinada narrativa de trauma e resiliência. Ao conferir uma linearidade temporal, a história da ex-criança soldado sem nome ou digital acaba sendo contada e recontada pelas mesmas palavras e no mesmo tom, suas entradas e saídas estão no passado militar e no futuro estável, o presente é um ato de espera.

A visão das ex-crianças soldado como resilientes é suportada por entre certos discursos que as colocam, primeiramente, em contraposição ao modelo do sujeito traumatizado; sem negar o impacto, essencialmente negativo do passado militar, esta concepção ressalta a capacidade da criança de superar as dificuldades e de se fazer, mentalmente, bem mesmo depois do envolvimento militar. Desse modo, ao contrapor a passividade e vitimização da ex-criança soldado como traumatizada, cuja decisão é sempre tomada por outrem (adulto), com a sua capacidade e habilidade de lidar com e superar as situações do conflito, o paradigma da resiliência é entendido como aquele que concede à criança certa agência ${ }^{20} \mathrm{em}$ relação à superação de seu passado militar.

Assim, se, de um lado, as relações estabelecidas pelos discursos do trauma, privam as ex-crianças soldado de escolhas e subestimam as suas capacidades de lidarem com o estresse do envolvimento do conflito, sob tutela de uma gramática médica e individualista, de outro, "a resilience paradigma is usefull because it emphasizes the importance of building on the existing streght of children, families, and communities." (Stark; Wessells, 2013, p. 96). O modelo da resiliência como

\footnotetext{
${ }^{20}$ Seguindo a reflexão de Watson (2015), as crianças são construídas como não tendo "poder" perante o sistema internacional, por isso, a discussão sobre sua posição entra na condição de vítima e dependência, sendo incapaz de tomar decisões por si só.
} 
oposto ao do trauma, seja em relação ao foco temporal e/ou à capacidade ou incapacidade da criança, faz parte de um mecanismo de afirmação que organiza as histórias e estórias das ex-crianças soldado e o locais de fala dos sujeitos sob a possibilidade de um futuro estável no mundo adulto.

Demais configurações do discurso da resiliência para o passado militar, de acordo com uma abordagem mais medicalizada e individualizada, afirmam que, mesmo em face a adversidades severas, as ex-crianças soldado não apresentam sinais de psicopatologia. Isto é, a situação esperada para a categoria ex-criança soldado se encontra amarrada, primeiramente, na sua posição de enfermidade e vulnerabilidade, para, posteriormente, ser pensada como resiliente, através de pesquisas que apontam a ausência de patologias mentais.

Como exemplo, Klasen et al. (2010) organizaram um estudo com ex-crianças soldado de Uganda, mais especificamente dentro da escola primária de Gulu Town no norte do país (uma quantidade de 330 ex-crianças soldado participaram da pesquisa pelo preenchimento de questionários), e concluíram que "despite severe trauma exposure, a critical proportion of former child soldiers showed a posttraumatic resilience outcome. " (p. 1110). Os autores definem a resiliência póstraumática, neste sentido, como a ausência de psicopatologias clínicas significantes após exposição severa a um trauma.

I want to get a sewing machine so that I keep on making clothes and sell them to get some money. [Ex-menina soldado, quinze anos, Uganda]. (Klasen et al., 2010, p. 1096).

I will be a person who is responsible in the community; I will be an honest person; I will be a person who helps people. [Ex-menino soldado, dezesseis anos, Uganda]. (Klasen et al., 2010, p. 1096).

As duas falas das ex-crianças soldado apontam para a orientação futura de seus planos, nas possibilidades de adaptação à sociedade adulta e nos movimentos que as encaixam em possíveis sujeitos (adultos) normalizados em formação e livres de psicopatologias. Esse enfoque produz um efeito de alocação do discurso da capacidade e superação (mais bem acomodado no mundo adulto) na concepção da ex-criança soldado e de sua recuperação. No entanto, o que também acaba sendo projetado é um caminho específico para ‘ficar bem', que é lançado em planos 
futuros, na esperança da ordem e estabilidade, já que o presente das ex-crianças soldado continua suspenso.

As críticas ao modelo do trauma ou, mais precisamente, do diagnóstico tido como universal e geral do distúrbio do estresse pós-traumático teve início nos anos de 1990 e ganhou abrangência nos anos 2000. Essas análises não se apresentaram somente no campo das Relações Internacionais críticas, mas também dentro dos Campos Humanitários e das Ciências Médicas, questionando e chamando a atenção para o porquê da prevalência das altas taxas de PTSD entre populações inteiras que passaram por conflitos e/ou desastres. Assim, a primazia do PTSD começou a ser questionada por várias abordagens, problematizando, principalmente, a abrangência quase natural de sua aplicabilidade, capaz de diagnosticar qualquer pessoa que presenciasse um conflito ou um desastre do mesmo modo. (Howell, 2012).

Interseccionando ao citado acima, é necessário mencionar que as objeções ao modelo psicossocial de resposta a conflito e desastres, de acordo com Howell (2012), seguiram duas direções. A primeira, inspirada nas referências ao paradigma da resiliência, questiona a medicalização excessiva do modelo do trauma, seja por meio das conotações patológicas concedidas ao PTSD, pela generalização de seu diagnóstico, pela ênfase imediata aos programas de tratamentos psicossociais nos processos de intervenção humanitária, seja, por fim, pela noção universal do diagnóstico que silencia as demais relações culturais, sociais e contextuais com o evento.

Já a segunda corrente desafia o modelo psicossocial do PTSD, concentrandose na revigoração das perspectivas biomédicas para a ajuda humanitária no campo psicológico e psiquiátrico. Com foco ainda mais no modelo médico, esta corrente apoia sua atenção na busca pelo lugar das 'doenças mentais severas' (como exemplo: transtorno bipolar, esquizofrenia, depressão e ansiedade severas, entre outras) dentro da intervenção humanitária, revelando uma necessidade de diferenciá-las do diagnóstico do PTSD e concedê-las condução especial. (Howell, 2012).

Dada essas vertentes de análise, a autoridade do PTSD como diagnóstico recorrente e universalizado se viu cedendo lugar para essas duas correntes críticas, primeiro aos modelos relacionados à saúde pública de prevenção, aprimoramento de capacidades e resiliência e, segundo, através de modelos neurobiológicos e 
biomédicos e sua mudança de foco antes da mente e psique para o cérebro. Além disso, as críticas ao discurso do trauma e ao diagnóstico do PTSD, mais especificamente aquelas localizadas no primeiro grupo, reconhecem que os diagnósticos, em realidade, são construídos e não simplesmente descobertos, por isso, pensar sobre o trauma e o PTSD é situá-los cultural, política e socialmente nas variadas experiências do contexto.

A central assumption behind psychiatric diagnoses is that a disease has an objective existence in the world, whether discovered or not, and exists independently of the gaze of psychiatrists or anyone else. In other words, neolithic people had post-traumatic stress disorder as have people in all epochs since. However, the story of post-traumatic stress disorder is a telling example of the role of society and politics in the process of invention rather than discovery. (Summerfield, 2001, p. 95).

Como exemplo, a história do diagnóstico PTSD está amarrada ao legado do pós-guerra do Vietnã; tendo sido uma invenção estadunidense, esta desordem procurou tornar compreensível a situação psicológica dos soldados dos EUA em seu retorno, ao encararem humilhação e desaprovação nacional em relação à ocorrência do conflito. (Summerfield, 2001).

Outrossim, a resiliência construída, neste caso, como um modelo alternativo/contrário ao diagnóstico do PTSD, igualmente, é produto de uma narrativa que reflete a possibilidade de 'melhor compreender' a realidade social e até internacional, movimentando as entrelinhas de determinados discursos que buscam produzir certos comportamentos, espaços e tempos específicos para o sujeito após o trauma. Ou seja,

[...] new times have brought new techniques: public health and prevention-based mental heathl models, resiliene, biomedical, neuro - and cognitive-oriented approaches, and positive psychology are now increasingly working to govern peolple's experiences of traumatic events. (Howell, 2012, p. 224).

Ademais, dentro das RI, a partir do modelo de segurança humana - que se firmou na metade da década de 1990 com o objetivo de desenvolver uma perspectiva mais centrada no indivíduo do que no Estado -, as intervenções humanitárias incorporaram o paradigma da resiliência em seus exercícios. Para Chandler (2012), tal concepção da segurança humana conseguiu se engajar com o paradigma da resiliência facilitando, de certo modo, a transição dentro dos discursos dominantes da segurança de um modelo intervencionista liberal para o da 
intervenção preventiva. Havia-se construído um esforço de empoderar e destacar a agência local, isto é, "in a post-interventionist/resilience paradigm, the emphasis is on prevention rather than intervention, empowerment rather than protection, and work upon the vulnerable rather than upon victims." (Chandler, 2012, p. 216).

A comunidade internacional se posicionaria, neste sentido, como facilitadora no processo de empoderamento, agenciamento e superação, tanto no âmbito individual quanto local, dos chamados 'mais vulneráveis'. Desse modo, o objetivo está em auxiliar na construção de mecanismos institucionais de boa governança e promover a resiliência entre os indivíduos. A mudança do vocabulário trazida pela resiliência enfatiza concepções de 'prevenção', 'emancipação' e 'capacidade', sendo capaz de retratar o modo como os discursos de segurança e de intervenções humanitárias se transformaram. Segundo Chandler (2013), portanto, "it appears that resilience practices are transforming security discourses from concerns with external threats to fears over the domestic or internal coping and adaptive capacities of individuals and their communities." (p. 212).

Sendo assim, percebo que, ao trazer o discurso da resiliência para a ex-criança soldado, vou também me envolvendo nessas outras histórias que sustentam sua (re)produção como paradigma alternativo ao trauma e ao diagnóstico do PTSD, cujos entornos também marcam outras concepções de 'ordem' e 'estabilidade' nos discursos de segurança dentro das RI. Contudo, assim como os discursos do trauma, a narrativa plural da resiliência para a ex-criança soldado aloca um entendimento temporal específico para sua categoria, além de moldar histórias e comportamentos esperados para seus sujeitos. Mas, há que se atentar para o fato de que qualificar uma ex-criança soldado como resiliente transparece relações outras, não somente de capacidades e adaptabilidade, mas também do foco temporal do prefixo 'ex'. Vejo que, neste caso, o 'ex' que marca o passado militar se mostra orientado para a esperança de um futuro estável, para a posição do sujeito adulto que está se formando e na possibilidade de minimizar os efeitos negativos do passado militar ao reconfigurar o olhar para um futuro tido como positivo.

Dessa forma, o caminho da superação deste passado militar está, intimamente, conectado à possibilidade de produzir um ideal de futuro para excriança soldado no seu desenvolvimento como adulto e criar espaços e tempos para pensar e projetar a sua capacidade e habilidade de superação por meio de sua entrada no mundo adulto como sujeito saudável e, emocionalmente, estável. “One 
of the most impressive phenomena of child development is the ability of many children to develop into healthy, well-adapted adults despite adversity and trauma." (Klasen et al., 2010, p. 1097). Conforme se constata, as ex-crianças soldado como resilientes se mantêm em uma posição ambígua no presente que marca sua maior capacidade de superação ainda em processo, na esperança de um futuro adulto saudável.

\section{4}

\section{A (re)produção do discurso do trauma e da resiliência para a ex- criança soldado}

Nesta parte, pretendo mostrar como os discursos da resiliência (em relação aos discursos do trauma) para a ex-criança soldado, presentes em três textos peculiares e diferentes entre si, produzem entendimentos temporal e subjetivo específicos para sua categoria. As histórias e experiências das ex-crianças soldado se ajeitam em uma mesma concepção sobre o ser criança e sobre os emaranhados temporais de rupturas entre o passado militar e o futuro do adulto. $\mathrm{O}$ discurso do retorno para a ex-criança soldado silencia os processos políticos acerca da construção de seu conceito e de sua adoção como categoria naturalizada e não questionada por entre as falas que a qualificam como traumatizadas ou resiliente.

Por essa razão, a minha análise tem como objetivo mostrar a importância de se atentar ao modo de operação de um conceito, questionando aqui como a categoria ex-criança soldado está sendo construída a partir, principalmente, de seus desenhos temporais (des)contínuos e imprecisos, uma vez que, embora os discursos do tratamento do trauma e da resiliência procurem ajeitar um entendimento temporal estável e seguro para a categoria ex-criança soldado - camuflada por entre os tempos verbais que conjugam a criança soldado, por isso (ex-) criança soldado - as relações descontínuas entre o prefixo 'ex' e o (pós-) conflito refletem quão ambígua, incerta e plural é a posição do ser ex-criança soldado e seu entendimento no presente.

Sendo mais uma interrogação do que uma afirmação, a categoria da excriança soldado transparece a impossibilidade de ser traduzida somente nas linhas do discurso do retorno e de ser acomodada confortavelmente no presente. Em virtude disso, há a necessidade de localizar o político entre os discursos do trauma e da resiliência para ex-crianças soldado que, por serem governados pelo 
conhecimento das aéreas médicas, tratam as categorias, as identidades, os objetos e as relações estabelecidas entre eles como naturais e independentes de seu contexto político e social. Consequentemente, entendo que " to understand language as political is to see it as a site for the production and reproduction of particular subjectivities and identities while others are simultaneously excluded." (Hansen, 2006, p. 16, itálico no original). Segundo Shapiro (1988), disciplinas como as Ciências Biológicas, por exemplo, falham em não perceber a literalidade de seus discursos quando afirmam que os significados e os entendimentos construídos neles possuem uma certa origem extralinguística.

Desatentos, portanto, à produção social e à histórica da categoria ex-criança soldado, seu entendimento é referido como universal e geral, capaz de ser transferido para outros textos e localidades sem mudança de entendimento e/ou sentido. Porém, o que pretendo mostrar é como a atuação das forças naturalizadas tornam inteligíveis certos discursos enquanto outros são silenciados; quando a categoria ex-criança soldado adquire uma função explicativa e nominativa por entre certos discursos, sendo que os interesses e os poderes definidos pela produção de seu conceito, igualmente, devem ser levados para a análise, porquanto, o que de qualquer conhecimento está intimamente relacionado ao como de sua escrita/fala.

To analyze how things in the word take on meanings, it is necessary to analyze the structure of our imaginative processes. The imaginative enactments that produce meanings are not simply acts of a pure, disembodied consciousness; they are historically developed practices that resides in the very style in which statements are made, of the grammatical, rhetorical, and narrative structures that compose even the discourses of the sciences. (Shapiro, 1988, p.7).

Além disso, gostaria de apontar o quanto uma análise crítica da categoria excriança soldado é necessária para problematizar a naturalidade e passividade de seu entendimento e sentido nos discursos dominantes sobre o tema; resultado da precariedade e/ou ausência de estudos que questionam sua (re)produção histórica, social e política, principalmente, nos discursos das Ciências Médicas. Em face ao dito, a partir da leitura dos três textos e seguindo por entre uma escrita crítica, analiso como específicos discursos do trauma e da resiliência (e suas relações) são destinados à ex-criança soldado, sendo capazes de produzir as identidades, qualidades, comportamentos e histórias esperados e de, simultaneamente, ser produzidos por eles. 
The productive nature of language implies that policy discourse is seen as relying upon particular constructions of problems and subjectivities, but that it is also through discourse that these problems and subjectivities are constructed in the first place. (Hansen, 2006, p. 15).

Por isso, nesta minha análise, a linguagem é tratada como um discurso e não como um meio de comunicação transparente entre sujeitos e objetos, sendo que "treating the language as discourse involves regarding language as a kind of practice." (Shapiro, 1988, p. 11). Também procuro destacar a conexão íntima entre linguagem e prática, o que me permite analisar os textos com base nos seus valores criados nas relações humanas e não em sua veracidade na comunicação. (Shapiro, 1988). Por não existir materialidade extralinguística, a produção da realidade material é mediada discursivamente, logo, linguagem e matéria não existem em separado, mas sim, em constante relação de (re)produção.

Nessa linha de raciocínio, os discursos da resiliência e do trauma para as excrianças soldado produzem-na como categoria, articulando subjetividades, identidades, ações e relações sociais e conjugando determinadas histórias em tempos cabíveis para o passado militar e o futuro do adulto, ao estipular o local de fala do sujeito narrador na racionalidade do ser resiliente. Ao analisar os três documentos, portanto, busco mostrar algumas das (des)contínuas e ambíguas relações que foram silenciadas na produção de um entendimento temporal específico para a categoria ex-criança soldado, imersa no discurso do retorno.

As histórias outras, estórias das ex-criança soldado que vão sendo silenciadas ao desenrolar das narrativas dominantes, constroem linhas de pluralidade, multiplicidade e ambiguidade na construção de sua categoria e sua posição temporal. Dissimuladas, essas histórias e estórias outras, de falhas, sussurros e descaso devem ser desmascaradas e mostradas, sem o objetivo de tornar coeso ou linear o tempo, o importante é manter a dispersão dos fragmentos temporais, múltiplos e heterogêneos por si só.

\subsection{1}

Handbook of resilience on children of war

Este livro acadêmico foi editado por Fernando e Ferrari, intelectuais da aérea da Psicologia na Universidade de Toronto (Canadá), e lançado em 2013. Conta com 
a contribuição intelectual de outros acadêmicos, a maioria também do campo da Psicologia e de Saúde Pública, sendo dividido em cinco seções com dezoito artigos, os quais buscam destacar como jovens e crianças demonstram resiliência mesmo em face do conflito armado.

A primeira seção, chamada Social-ecological approaches to promoting resilience in children of war, contém quarto artigos que exploram os modelos sociais e ecológicos de promoção da resiliência e de sua aplicação para o bem-estar psicossocial. A segunda parte, Child soldiers, conta com três artigos e procura analisar, particularmente, a relação entre resiliência, as crianças soldado e as excrianças soldado, seja durante seu envolvimento militar e/ou nos processos de reintegração social. Na terceira seção, Institutional support for children affected by $w a r$, os dois artigos discutem sobre o apoio institucional desenvolvido para as crianças afetadas pelas guerras, seus métodos e projetos a fim de promover a resiliência. A quarta parte, Resilience among refugees, possui mais cinco artigos acerca da resiliência entre crianças refugiadas e seus meios de promoção. Por último, na quinta seção, Extending our understanding of the effects of war on children: theory and practice, quatro capítulos buscam trazer reflexões sobre a teoria e a prática da resiliência com o intuito de questionar e expandir o entendimento do conceito.

Como meu foco está na análise dos discursos que (re)produzem a categoria ex-criança soldado e suas posições temporais, pretendo, neste momento, dar mais atenção aos três artigos da segunda parte, intitulada Child soldiers, cuja proposta está, especificamente, na promoção do discurso da resiliência em relação ao envolvimento militar infantil e à reintegração social das ex-crianças soldado. Todavia, busco, igualmente, discutir sobre os métodos e apoios sociais e ecológicos da resiliência que embasam as argumentações dos capítulos. Por conta disso, mostrarei aqui como os discursos da resiliência (em constante relação aos discursos do trauma) modelam um entendimento temporal específico para a categoria excriança soldado entre um passado militar e o futuro do adulto, em que os entornos do ser resiliente se manifestam pela possibilidade de projetar certas esperanças ao futuro. 


\subsubsection{1 \\ Capítulo seis: When children become killers: child soldiers in the civil war in Sierra Leone}

No capítulo sexto When children become killers: child soldiers in the civil war in Sierra Leone, Zack-Williams (2013) articula uma relação entre a resiliência das crianças e jovens de Serra Leoa com o antes, o durante e o depois da guerra do país. Consoante o autor, o conflito civil armado em Serra Leoa e a utilização de crianças como combatentes por ambos os lados teve seus caminhos ligados e explicados por uma "confrontação intergeracional" (p.90) em que jovens (homens e mulheres) se opunham aos chefes tradicionais e elites urbanas por uma mudança na estrutura social. Com o objetivo de ocupar uma posição mais significativa na vida política e econômica do país e trazer mudanças nas suas condições sociais, crianças e jovens no (pós-) conflito desenham suas relações na busca de maior atuação e voz.

Partindo dessa lógica, Zack-Williams nos mostra que a participação da criança na guerra causou um choque nos valores e ideais pré-estabelecidos para a criança dentro dos costumes nacionais, como o respeito inquestionável aos mais velhos, por exemplo.

[...] the phenomenon of child combatants and the general precarious position of children in Sierra Leone brought their parlous state to the attention of the world. Participation in the war politicised the nation's youth and gave them a sense of empowerment as the two main parties sought their votes in the post-war elections. (2013, p. 90).

Para o autor, ademais, um dos principais fatores que levaram à guerra civil de Serra Leoa foi a marginalização e a percepção de impotência das crianças e jovens, levando-os ao conflito armado, cuja relação entre o antes, o durante e o após denota a busca daqueles por mais espaço na vida pública.

Friso que, antes de entrar, especificamente, na discussão sobre a relação entre resiliência das (ex-) crianças soldado e (pós-) conflito desenvolvida por ZackWilliams, pretendo destacar os sentidos 'misturados' dos termos criança soldado e criança combatente usados, praticamente, como sinônimos e também refletir sobre a ideia de guerra trabalhada no texto.

Primeiramente, o autor traz o conceito de criança soldado como sinônimo de criança combatente, porém, esta função de combatente é uma das demais posições 
ocupadas pelas crianças envolvidas em grupos armados, podendo ser espiãs, mensageiras, cozinheiras, etc. Sendo assim, quando a definição de criança soldado é atrelada somente ao seu status de combatente, outras histórias e estórias sobre o (pós-) conflito e seus contornos temporais são silenciadas pelos discursos que formam sua categoria, além de fixar um entendimento temporal específico, situando a criança soldado no presente com sua arma de fogo. Isto é, a criança combatente como imediato entendimento da categoria criança soldado no presente simplifica a relação entre o mundo da infância moderna e do conflito armado moderno e de como uma ideia de resiliência conseguiria abraçar o construído distanciamento entre eles.

Acrescenta-se a isso que concepções referentes aos termos crianças e jovens são articuladas como juntas em uma esfera explicativa comum e, muitas vezes, como indiferenciáveis. Percebo que essas modelagens discursivas são responsáveis por realçarem um efeito do ser resiliente junto aos seus contornos temporais e contam uma narrativa sobre o conflito armado no singular.

Ainda que Zack-Williams destaque que o fenômeno da criança soldado foi/é uma característica universal, presente tanto nas guerras 'tradicionais' quanto nas 'novas', a concepção da guerra civil de Serra Leoa como brutal (e também a dita precariedade estrutural no pré-guerra) traduz uma certa (re)produção da categoria (ex-) criança soldado por entre incompletudes e falhas do Estado moderno dentro de um discurso colonial. Esses discursos projetam um entendimento da guerra como ligada, essencialmente, ao caos e à desordem do Estado pós-colonial de Serra Leoa e ao 'descuido' com seus jovens e crianças; assim, uma ideia de resiliência viria como em embate e enfrentamento dessas condições. Como afirma o autor, "the war points out both the resilience of young people, including their capacity for creative survival strategies and the hardship they have endured in post-colonial Sierra Leone." (2013, p. 82).

Neste sentido, mostro aqui como esta ideia de resiliência no texto para a categoria (ex-) criança soldado mobiliza uma relação específica sobre a projeção de uma ordem e estabilidade, nesse caso, desenhada entre o Estado Moderno e a criança combatente. O conceito de resiliência, neste texto, é definido como uma construção multidimensional capaz de construir uma interação bidirecional entre indivíduo e seu meio. Por isso, os quatro aspectos da resiliência - trazidos por ZackWilliams (2013, p.91) de acordo com American Psychological Association - são: 
1) consciência crítica, a qual promove uma capacidade de questionar as condições sociais existentes; 2) agência ou engajamento ativo que trazem impactos positivos para seu meio; 3) flexibilidade social e emocional; 4) comunalismo - celebração dos laços sociais.

Para o intelectual, portanto, esses aspectos orientam o modo de se pensar a resiliência para a categoria (ex-) criança soldado por entre o antes, o durante e o após o conflito armado em Serra Leoa. Nesses discursos, jovens e crianças no país, além disso, são consideradas resilientes por lutarem contra as condições sociais e etárias existentes em seu meio, seja em relação à violência do conflito seja pela própria posição de marginalização social e pública no pré- e pós-conflito. Desse modo,

[...] the immediate effect of war was to embolden young people in Sierra Leone, whose existential characteristic was defined as a group who can be seen, but not heard. By the time the war ended, however, they had made their presence felt largely because of their role as child combatants in challenging adults for the future of the state. (2013, p. 92).

Neste excerto, a posição da criança soldado como combatente em Serra Leoa tem sua projeção ligada à concepção de resiliência em sua alocação no presente, como questionadora das condições sociais do seu meio, sendo também projetada quando o prefixo 'ex' entra em cena e as ex-crianças soldado (como excombatentes) retornam à comunidade. $\mathrm{O}$ entendimento da criança soldado como resiliente no presente - analisada em um determinado contexto - representa um desafio à imagem tradicional do ser criança soldado como 'problema' social pela junção da criança mais a arma de fogo.

No entanto, concomitantemente, esse entendimento (re)conduz a uma ideia de ruptura e desemparo no que tange à produção de uma infância ideal, pois, a posterior resposta do internacional em Serra Leoa para as agora ex-crianças soldado toma forma por entre os processos de reintegração social (programas de DDR, por exemplo) entre o discurso do retorno e a resiliência, sendo que esta viria como uma marca ideal para esta volta: "the former child combatants showed much resilience in their new civilian roles as mechanics, carpenters and joiners, taxi drives and security personnel to politicians." (2013, p.92).

Deslizando por entre mudanças e permanências, as (des)continuidades temporais projetadas para a categoria (ex-) criança soldado neste discurso da 
resiliência mostram quão ambíguas e plurais são as experiências dessas crianças com o (pós-) conflito. Ora sendo jogada em um tom ativo, ora em passivo, ora vítima, ora participante do conflito, os discursos da resiliência aqui traduzem percepções plurais da categoria ex-criança soldado e seus contextos sociais, por mais que se tente estipular um encaminhamento específico para pensar a superação e sobrevivência do envolvimento militar.

Além disso, os desenhos temporais difusos da (ex-) criança soldado movimentam aqui superações que vão além do passado militar, pois, conforme Zack-Williams, ser resiliente é uma continuidade que marca a categoria (ex-) criança soldado no antes, no durante e no após o conflito de Serra Leoa. Entretanto, faz-se mister enfatizar que se trata de uma continuidade relacionada a um ideal de ordem do Estado Moderno (ocidental) e sua sociedade.

\subsubsection{2 \\ Capítulo sétimo: The fallacy of the ticking time bomb: resilience of children formerly recruited into armed forces and groups}

No capítulo sétimo, The fallacy of the ticking time bomb: resilience of children formerly recruited into armed forces and groups, Stark e Wessells (2013) começam questionando como a ênfase no modelo do trauma guia específicas respostas às ex-crianças soldado, encarando-as como vítimas passivas e com patologias que devem ser trabalhadas via intervenção e tratamento médico. Esse paradigma do trauma, portanto, subestima a capacidade e habilidade das excrianças soldado em lidarem com as dificuldades e se (re)encaixarem socialmente e, além disso, acaba focando somente no trauma proveniente da guerra e do envolvimento militar, silenciando outras experiências traumáticas capazes de existir na vida das crianças, seja antes ou após o conflito, como se percebe nesta passagem: “formerly recruited children's difficulties and traumatic experiences end once they are released from the armed forces or armed group whit which they served." (2013, p. 95).

Entendendo a resiliência como a capacidade de adaptar-se e funcionar razoavelmente bem apesar da exposição a adversidades (Stark; Wessells, 2013 apud Masten; Best; Gamezy, 1990, p. 95), os autores sugerem pensar a resiliência como novo paradigma, no intuito de compreender e apoiar as ex-crianças soldado na reintegração social e na construção de suas identidades civis, visto que a resiliência 
traz consigo a importância de se apoiar na construção de capacidades e forças das crianças, famílias e comunidades. Logo, foi percebida a necessidade de trazer um olhar diferente para entender a reintegração social das ex-crianças soldado a partir de um modelo que destaca o empoderamento, capacidade, agência e voz das crianças e jovens junto com o apoio social coletivo, Stark e Wessells (2013) exploram a resiliência como um paradigma, em contraposição ao modelo limitado do trauma.

Pautando-se nessa base analítica, de primeiro momento, os autores reconhecem uma dinâmica de poder existente nos programas de reintegração social das ex-crianças soldado, os quais são montados, aplicados e avaliados por adultos. Esta dominância do discurso adulto nos processos do retorno das ex-crianças soldado tende a incapacitá-las e infantilizá-las; tornando-se mais difíceis as relações sociais no (pós-) conflito, posto que, muitas vezes, as ex-crianças soldado já se veem como independentes e capazes de manejar seus próprios problemas e dificuldades. Neste ponto, acrescento que o discurso do retorno projeta um entendimento adulto sobre o (pós-) conflito e sobre a maneira de compreender o prefixo 'ex' por meio de ideais de salvação e resgate. Aqui, também trago a dúvida: os discursos da resiliência, plurais entre si, de certa forma, também não representam um olhar adulto de entender a superação da ex-criança soldado?

Stark e Wessells afirmam, por sua vez, que a resiliência como paradigma é capaz de apoiar as vozes e decisões das ex-crianças soldado no que tange aos seus processos de reintegração social e civil, não focando somente em uma perspectiva individualista sobre saúde mental, mas sim nas dinâmicas sociais e culturais da comunidade e das famílias. Essa visão relacional da reintegração social das excrianças soldado, que envolve também pensar nas dinâmicas sociais das comunidades, relaciona-se com o modelo social e ecológico da resiliência. Brevemente: o modelo da resiliência social e ecológica tem como objetivo analisar a resiliência por entre diversos níveis contextuais, além do dominante foco no indivíduo. Por isso, leva em conta também as relações sociais, familiares, culturais que interferem na percepção do indivíduo e na promoção da saúde mental das crianças afetadas pela violência. (Tol et al., 2013).

Ademais, no texto de Stark e Wessells, é frisada a necessidade de reconhecer como o impacto do conflito e do envolvimento militar varia de uma ex-criança soldado para outra, de acordo com o modo em que elas imputam sentido às suas 
experiências no grupo armado. Assim, penso que o entendimento 'automático' da ex-criança soldado como traumatizada simplifica as plurais vivências e relacionamentos durante o conflito e também do pós-conflito, quando a volta ao ambiente civil implica a construção de novas relações sociais projetadas pela superação do passado militar. Podendo, nesse sentido, as ex-crianças soldado terem mais frustações e angústias devido às difíceis condições no pós-conflito, seja pelo desemprego, marginalização, insegurança, pobreza, não-aceitação social e falta de acesso à educação seja pelos eventos do passado militar. (p.98).

Segundo Stark e Wessells, existem alguns suportes principais a serem desenvolvidos - com base na concepção de resiliência presente no texto - a fim de auxiliar a reintegração social das ex-crianças soldado. Entre eles estão os apoios psicossociais capazes de abranger os diferentes impactos do envolvimento militar em cada criança e abraçar não somente o campo individual, mas também a comunidade e família. Depois, vem o apoio às práticas culturais e espirituais locais que podem ajudar as ex-crianças soldado a lidarem com as dificuldades e a se reinserirem na sua comunidade.

Além dessas ações, definem outras: promover acesso à educação, contribuindo também para a construção de uma rotina e senso de normalidade e continuidade; trazer como prioridade o oferecimento e fortalecimento de programas econômicos e meios de sustento, atentando às necessidades individuais e coletivas das crianças, como exemplo, promover uma ajuda apropriada às ex-meninas soldado mães no pós-conflito. Por fim, os autores apontam a mobilização da comunidade e reconciliação, realçando a importância de construir a resiliência por entre a comunidade transformando, positivamente, as relações sociais no pósconflito e, assim, abrir espaços de aceitação para as ex-crianças soldado.

Ao final do texto, Stark e Wessells lançam uma discussão acerca do ser resiliente, afirmando que é um erro supor que uma criança, por ser caracterizada como resiliente, não necessite de apoio ou suportes físicos e psicossociais, pois, "different children may need different kinds of support." (2013, p. 102). Acrescentam que, apoiar-se na concepção de que as ex-crianças soldado estão entre as mais vulneráveis no (pós-) conflito é, muitas vezes, problemático, visto que as crianças que estão ou estavam dentro de grupos armados têm/tiveram mais possibilidade de acesso a comidas e medicamentos do que os jovens e crianças que vivem em áreas de ataque. (2013, p. 103). 
A partir desses pontos de discussão da categoria ex-criança soldado presentes no texto de Stark e Wessells, percebo que a relação temporal entre a (ex-) criança soldado e o (pós-) conflito se dá de modo a afirmar um passado a ser superado e amenizado, seja do soldado ou do conflito, e um futuro a ser esperado de convivência harmoniosa, reconciliação e possibilidades com e na comunidade, levando-se em consideração que o foco do capítulo está no 'ex' da ex-criança soldado e no pós do pós-conflito, quando a resiliência entra em cena através de um certo discurso do retorno que (des)envolve e se apoia mais em uma ideia do alinhamento, estabilidade e ordem social do que no aspecto individual de saúde mental.

Trabalhando com uma concepção de resiliência ecológica e social, as relações individuais e coletivas se mostram igualmente importantes no desenho da reintegração social bem-sucedida das ex-crianças soldado e na promoção do ser resiliente, sendo capazes de projetar uma ordem social desejável que emana, principalmente, das novas relações sociais dentro da comunidade. Pautando-me nisso, acredito que, de outro viés, o aspecto individual da ex-criança soldado como resiliente toma forma quando o discurso de superação e adaptação chega para the conceder uma voz e história - no singular - cujo envolvimento militar é conjugado no passado e os planos e desejos futuros ganham destaque. Nesse sentido, esses planos e esperanças para o futuro estão de acordo com a (re)construção da ordem e das relações sociais no pós-conflito, sendo que a possibilidade de participação, decisão, voz e atuação das ex-crianças soldado, nesses processos, estão em consonância com esta projeção de certa estabilidade e que só assim conseguem ser traduzidos.

Dessa maneira, a resiliência como o outro paradigma em contraposição ao do trauma, neste texto, viria para orientar a categoria ex-criança soldado em direção à esperança do futuro adulto desejável, em que agência e autonomia ganhariam o seu sentido pleno dentro da comunidade. Além disso, o ser resiliente está, temporalmente, relacionado com o prefixo 'ex' no que tange à superação do passado militar em vista a uma reintegração bem-sucedida das ex-crianças soldado na sua comunidade, capazes de ser promovidas e gerenciadas, visando o bem-estar no futuro. 


\subsubsection{3 \\ Capítulo oitavo: Children of war in Colombia and Iraq}

Nesse capítulo, Children of war in Colombia and Iraq, Buchanan et al. retratam como a maioria dos estudos no campo das crianças afetadas pela guerra focam, quase exclusivamente, nas psicopatias desenvolvidas pelas mesmas durante o conflito. Porém, segundo os autores, "we also need to understand how the trauma of war is mediated by children's coping capacities, belief system, cultural ideologies and familial and social relationships." (2013, p. 108). Assim, este capítulo busca analisar duas pesquisas qualitativas realizadas pela University of British Colombia, no Canadá, acerca de dois estudos narrativos: um com excrianças soldado na Colômbia e outro com crianças afetadas pela guerra durante a ocupação do Iraque.

Como meu objetivo é analisar os discursos da resiliência e do trauma que produzem a categoria ex-criança soldado e sua alocação temporal, pretendo explorar aqui os estudos sobre as ex-crianças soldado na Colômbia, visto que, nessa análise da ocupação do Iraque, as crianças afetadas pela guerra não estavam envolvidas em grupos armados.

Buchanan et al. (2013) analisam a resiliência das (ex-) crianças soldado colombianas que foram capturadas ou rendidas pelas forças governamentais e que, igualmente, participaram dos programas de reintegração social em Bogotá. Desse modo, um grupo de 23 ex-crianças soldado foi selecionado para participar da pesquisa, preenchendo os questionários (Child's reaction to traumatic events scale e Structures interview for disorder of extreme stress) com o intuito de identificar se possuíam sintomas relacionados ao trauma e qual seria sua intensidade. Dentre estas 23 ex-crianças soldado, seis (quatro meninos e duas meninas) foram entrevistadas, individualmente, tendo eles contado suas experiências particulares sobre o conflito e o envolvimento militar. As discussões e análises sobre esses dados levaram os autores a trazerem questões sobre os comportamentos das ex-crianças soldado capazes de tradução sob o olhar da resiliência.

Os pesquisadores notaram que as ex-crianças soldado colombianas, como exemplo, mostraram um senso de agência, tendo determinação e iniciativa para esquematizarem planos e estratégias de sobrevivência durante e depois de sua estadia no grupo armado. Muitas delas afirmaram que buscavam se lembrar de suas 
raízes e de seus relacionamentos familiares anteriores, quando estavam dentro dos grupos armados, com o intuito de se controlarem internamente e de se autoafirmarem. Os autores afirmam que essas ex-crianças soldado também apresentaram habilidades como inteligência social e empatia na busca de pertencimento a um grupo e de ganharem aceitação social, sendo capazes de levar a perspectiva do outro em conta e controlarem suas respostas emocionais em momentos de coação, movimentos necessários para suas sobrevivências. Além disso, elas foram capazes de estabelecer conexões com a comunidade e de compartilhar suas experiências com outras pessoas - descrito como um dos principais fatores auxiliadores na superação do trauma da guerra.

Um dos pontos mais significativos para minha análise se encontra na relação entre resiliência, senso de futuro, esperança e crescimento pessoal. Isto é, as excrianças soldado colombianas foram consideradas resilientes, entre os demais fatores acima, também porque descrevem suas experiências como crianças soldado no tempo do passado, não mais se identificando como soldado e considerando suas experiências na guerra como dolorosas. Ademais, no momento atual, elas descrevem suas experiências no grupo armado como de aprendizagem e de crescimento pessoal, sendo que " the children in this study demonstrated resilient capacities to overcome child-soldiering experiences and were able to use their experience as a source of future growth. " (Buchanan et al., 2013, p. 110).

Assim, observo que o ser resiliente se orienta na possibilidade de se projetar um futuro estável nas entrelinhas da superação do passado militar, em que as histórias das ex-crianças soldado são contadas com base em ideais de pertencimento e esquecimentos. Por isso, quando o sujeito ex-criança soldado conta sua história sob a ótica da resiliência, seu passado militar deve estar no passado, junto com seus traumas; a tradução somente é possível quando a esperança de um futuro bom é projetada pelas narrativas das ex-crianças soldado resilientes.

De certa forma, a resiliência viria para 'ajeitar' as temporalidades entre as falas e conceder um lugar para as histórias das ex-crianças soldado. Apesar de os autores afirmarem que as (ex-) crianças soldado são resilientes também durante seu envolvimento militar, o tom de futuro que norteia a relação de superação e duração mostra que o envolvimento militar é (ou tem que ficar no) passado para o retorno a uma normalidade. 
Concluo esta parte com as frases finais do texto de Buchanan et al. sobre a relação entre resiliência, futuro e esperança capazes de projetar a categoria excriança soldado por entre os anseios do internacional: "Focusing on child resilience in war-torn countries brings us hope. It does not, however, alleviate our goal responsibilities to respond to their suffering." (2013, p. 115).

\subsection{2 \\ IASC ${ }^{21}$ Guidelines on Mental Health and psychosocial support in emergency settings}

Este guia foi elaborado em 2007, com a finalidade de capacitar os atores humanitários e a comunidade afetada a produzir, coordenar, organizar e aplicar mínimas e multissetoriais respostas, durante uma situação de emergência, para proteger e melhorar a saúde mental das pessoas envolvidas e seus bem-estar psicossociais. (p.5). Em razão disso, a linguagem aqui utilizada segue um formato diferente dos textos acadêmicos, sendo a promoção (do discurso) da resiliência, envolvida em pontos práticos de atuação, ligada à elaboração e coordenação de ações específicas entre atores humanitários governamentais e não-governamentais.

Alguns dos artigos dentro do livro Handbook of resilience on children of war trazem análises ou citações deste guia sobre os suportes sociais necessários em conflitos armados para a proteção da saúde mental das crianças e da comunidade. Pretendo englobar algumas de suas argumentações por entre as minhas reflexões sobre a categoria ex-criança soldado.

Além disso, este documento representou um esforço dos profissionais de diferentes regiões geográficas, disciplinas e setores para criar um consenso sobre boas práticas nesta área de atuação. A composição dos termos saúde mental e bemestar psicossocial descrevem tipos específicos de suportes locais ou estrangeiros que buscam proteger e/ou promover o bem-estar psicossocial, além de prevenir ou tratar distúrbios mentais. A definição desses dois termos, segundo a IASC, varia de organizações, disciplinas e países, porém a utilização deles juntos neste documento

\footnotetext{
${ }^{21}$ Inter-agency Standing Committee é uma interagência, estabelecida pela Assembleia Geral das Nações Unidas, para coordenação, desenvolvimento de políticas e tomada de decisões pelos executivos chefes das principais agências humanitárias, como Cruz Vermelha, Agências da ONU e organizações humanitárias não-governamentais. (2007, p. 19).
} 
"serves to unite as broad group of actors as possible and underscores the need for diverse, complementary approaches in providing appropriate support. " $(2007$, p.2).

Segundo o guia, os problemas psicossociais e a saúde mental da comunidade durante situações de emergências vão além das experiências do PTSD, reconhecendo as pessoas afetadas não como vítimas passivas, mas sim como construtoras de sua realidade social e capazes de contribuir para a implementação dos programas. Nessas premissas, as ações humanitárias devem incluir a participação da população, pois muitas pessoas se mostram, suficientemente, resilientes e podem participar dos processos de reconstrução e ajuda. Assim, o texto enfatiza que é necessário focar e reforçar os recursos já existentes na população afetada que auxiliam na promoção da saúde mental e no bem-estar psicossocial.

A estrutura do documento conta com uma matriz (capítulo segundo) mais um conjunto de planos de ações (capítulo terceiro). A matriz detalha as ações dos vários atores durante diferentes estágios de emergências, sendo dividida em três colunas sobre os principais pontos de recomendações e suportes: 1) Preparação para emergências (passos para tomar antes da emergência ocorrer); 2) Respostas mínimas (representam as primeiras atitudes que devem ser tomadas perante uma situação de emergência); 3) Respostas abrangentes (ações para serem implementadas depois das respostas mínimas, geralmente, durante a estabilização e a recente fase de reconstrução da emergência). O capítulo terceiro explica o modo de implementação das respostas mínimas em cada situação.

Ademais, reconhecendo que, em situações de emergências, as pessoas são afetadas de maneiras diferentes e requerem diferentes tipos de suporte, os programas humanitários aqui se apoiam em um sistema em camadas de suportes complementares. Ou seja, este sistema de múltiplas camadas é dito como capaz de abranger as necessidades dos diferentes grupos quando atuadas juntas e é conduzido em analogia a uma pirâmide. (p. 10).

$\mathrm{Na}$ base, encontram-se os serviços básicos e segurança, que seriam o restabelecimento da segurança, promoção dos serviços básicos como comida, água, abrigo, cuidado de saúde básico, etc. a fim de garantir a proteção imediata das pessoas. Logo acima da pirâmide, estão os suportes da comunidade e família, respostas de emergência a um grupo menor de pessoas que necessitam de ajuda para acessar suportes da comunidade e das famílias, como exemplo do rastreamento e 
reunificação familiar, programas de suporte para pais, atividades educativas formais e informais, entre outras.

A terceira camada está relacionada com suportes focados e nãoespecializados referentes aos suportes destinados a um grupo pequeno de pessoas que, adicionalmente, necessitam de auxílio individual, familiar e de grupo por trabalhadores treinados (mas não, necessariamente, especializados), como cuidados básicos de saúde mental, por exemplo. Finalmente, no topo da pirâmide, estão os serviços especializados que representam suportes adicionais destinados a uma pequena parcela da população que sofre com transtornos e dificuldades nas funções diárias básicas, necessitando de ajuda formal e especializada. (p.12-13).

De acordo com Magid e Boothby (2013), as ex-crianças -soldado se encontram na camada dos suportes focados e não-especializados, que necessitam de maior ajuda. Além de suporte psicossocial e são desenvolvidos programas de autoajuda, para o bem-estar físico e mental, entre outros. Como exemplo, os autores trazem o programa coordenado pela Save the Children em Moçambique, no Centro de reabilitação Lhanguene (1988), destinado à reintegração social de (ex-) meninos soldado recrutados pela Renamo. Este centro contava com diferentes tipos de suporte: desde estabelecimento de segurança e controle emocional até o rastreamento e reunificação familiar, apoiando-se na combinação dos 'suportes em camadas' desenvolvidas pelo guia.

Destarte, a partir desta apresentação do documento, pretendo trazer como a categoria ex-criança soldado está sendo formada nesses discursos da promoção da resiliência no campo de atuação humanitária. Nessa perspectiva, percebo que há poucas referências ao entendimento da ex-criança soldado; em realidade, o termo aparece somente uma única vez no texto, dentro de um plano de ação sobre proteção e direitos humanos. Já as expressões crianças recrutadas ou usadas por forças armadas ou grupos armados aparecem três vezes ao longo do documento. O seu primeiro aparecimento vem para mostrar que existem grupos de pessoas que, frequentemente, correm maiores riscos nas mais diversas situações de emergência, sendo a criança soldado uma delas. Contudo, o guia explica que, ao identificar grupos de pessoas em risco, não está sugerindo que sejam vítimas passivas das situações, mas que são, igualmente, capazes de contribuir para a vida política, social e religiosa, isto é, são, em muitos casos, resilientes. 
Na segunda vez, o termo está disposto na coluna das respostas abrangentes após a aplicação das respostas mínimas - dentro da matriz e vem relacionado com o suporte e mobilização da comunidade, isto é, “ facilitate community-based reintegration of children recruited or used by armed forces or groups" (IASC, 2007, p. 27) está como imperativo na busca da estabilização social. Esses dois movimentos - estar no grupo de risco no presente e, ao mesmo tempo, poder ser resiliente e ser resiliente por reintegrar à comunidade e suas estruturas - apontam para a alocação temporal difusa do prefixo 'ex' em relação aos discursos da resiliência para a (ex-) criança soldado. Permanecendo, ainda, nos rastros futuros de participação, aprendizado e retorno, os discursos da (ex-) criança soldado resiliente moldam cenários futuros sobre a esperança do ser, enquanto o momento presente continua sendo a espera, seja da preparação (antes), do risco (durante) e do retorno (depois).

Acrescenta-se a isso que, na parte dos planos de ação, o termo crianças recrutadas por forças armadas aparece também dentro do tópico Proteção $e$ direitos humanos, visando implementar proteção legal com o objetivo de promover o bem-estar psicossocial, dignidade e respeito (Action Sheet 3.3, tópico 5). Com vistas a enfatizar a importância dos processos legais para o bem-estar psicossocial, o guia aponta para a peculiaridade do grupo das (ex-) crianças soldado, "ensuring that customary law processes of accountability are followed, as these may be essential to communities' acceptance of children recruited by armed forces. " (2007, p. 67).

Do mesmo modo, o conceito ex-crinça soldado surge como pertencente, novamente, a um grupo de risco, em que certos cuidados devem ser tomados para garantir suas proteções e direitos. O guia traz o termo atrelado à questão de exposição como sinal de alerta, visto que a atenção midiática pode causar um ataque de retaliação contra ex-crianças soldado devido às suas exposições. Tomando como base de análise este enfoque, pretendo mostrar que, além de qualificar as (ex-) crianças soldado como resilientes - e, assim, envolvidas em projetos que visam ao futuro de estabilidade, seja individual ou coletivo - o guia, igualmente, trata da posição de sua categoria como incerta e difusa por entre os desejos de reconciliação e justiça na comunidade, em que a condição de criança (da infância moderna) ganha prioridade no discurso do retorno. O modelo de escrita do documento acaba trazendo muitos elementos e conceitos sem questionamentos e análises, sendo que, 
neste caso, o termo ex-criança soldado se mantém camuflado por entre ideais de estabilidades e superação que (re)produzem um ideal de retorno social para sua categoria.

\subsection{3 \\ Muito Longe de Casa: memórias de um menino-soldado}

Resolvi, entre outros motivos, trazer este livro para análise também em virtude do jogo temporal presente em seu título e como os difusos desenhos temporais do ser (ex-) criança soldado são traduzidos pela relação entre o termo memórias (remetendo ao retorno narrativo de eventos passados) e depois de um menino-soldado (refletindo o ser no presente do envolvimento militar). Penso que esta projeção do passado no presente, assim como na música de Emmanuel Jal com a flexão temporal dos verbos, mostra as possibilidades de trazer ao presente o passado militar no agora adulto que narra sua história de superação.

Caberia aqui o prefixo 'ex'? Onde estaria a categoria ex-criança soldado nesses termos? Percebo que são nas entrelinhas de um discurso sobre onde está o passado e o presente em que o tempo de espera da ex-criança soldado é projetado, o seu presente é a esperança e o aguardo. Quando não o é no agora, sua categoria é, de novo, camuflada por entre o foi criança soldado e é o adulto.

Sendo assim, como minha intenção aqui é analisar os discursos do trauma e da resiliência que (re)produzem a categoria ex-criança soldado, proponho selecionar certos momentos da trajetória de Beah capazes de conjugar seu envolvimento militar no passado, no tempo a ser superado. Ou seja, atentar-me-ei no movimento do desfazer do menino soldado, quando os entornos do prefixo 'ex' entram em cena, e os discursos do 'estar traumatizado' e/ou 'ser resiliente' projetam a sua categoria como ex-criança soldado. Desse modo, começo minha análise no evento em que o prefixo temporal 'ex' é acrescentado na categorização do ser menino soldado; sendo que, no caso de Beah, este evento foi trazido por rupturas, narrado entre o antes e o depois da chegada da equipe da UNICEF na aldeia de Bauya, onde tropas do exército se encontravam.

Ainda criança pela idade, quinze anos naquele evento, o menino soldado Beah foi escolhido pelo seu tenente para ser levado pelo pessoal da UNICEF junto com mais quatorze meninos soldado. Beah descreve este momento com angústia e 
dúvidas: "Por que o tenente estava nos entregando para aqueles civis? Pensamos que seríamos parte da guerra até o fim. O pelotão era minha família. Agora éramos levados, sem mais nem menos, nenhuma explicação dada." (2015, p. 143). E depois acrescenta, no momento em que, após ser desarmado, estava sendo levado ao caminhão: " não tinha me separado da minha arma desde o dia em que havia me tornado um soldado. " (p. 143).

Antes de entrar na análise desses eventos de rupturas que envolveram os processos de reintegração social de Beah no Lar Benin, trago uma reflexão sobre como a relação entre o conflito armado e o personagem vai sendo (des)construída por entre certos eventos de fuga, instabilidades e (re)começos. Até a página de número 121 (o livro tem um total de 254 páginas), Beah conta como seu percurso de longas caminhadas se deu a fim de fugir do conflito que se alastrava nas localidades. Quando a guerra começou a chegar em Yele, uma vila tida como segura e protegida pelo exército, Beah enfrentou um momento decisivo para sua jornada: permanecer na aldeia e lutar para o exército ou partir dali e continuar fugindo do conflito por sua conta e risco. "Sair da aldeia era a mesma coisa que morrer." (2015, p. 118). Ele escolheu permanecer, recebeu uma arma, treinamento e sua rotina militar começou a ganhar forma no presente, trazendo consigo o termo soldado em conjunto com o menino.

Posteriormente, a passagem entre o menino soldado e o ex-menino soldado, quando o seu envolvimento militar foi conjugado no passado, teve sua narração delimitada pela ruptura e, consequentemente, pelo distanciamento do ambiente militar e a alocação do ser criança (no singular) nos entornos do discurso do retorno. A longa viagem de caminhão da vila Bauya até o Lar Benin com o pessoal da UNICEF parece marcar instantes de interrogações e incertezas que traduzem as indecisas posições temporais do ser (ex-) menino soldado. Esta ruptura por (des)continuidades (representada aqui pela viagem) mostra a tentativa de separação física/espacial entre os mundos da guerra moderna e da infância moderna, por mais que o conflito continuasse ocorrendo e outras relações identitárias, subjetivas e temporais se estabelecessem de modo plural e ambíguo entre as durações do (pós-) conflito.

Os primeiros dias dos processos de reintegração social de Beah no Lar Benin foram marcados por momentos de tensão, agressividade, abstinência das drogas e incompatibilidade com o ambiente (civil) onde estava. As atividades que se 
seguiam buscavam reafirmar um ideal de ser criança - vulnerável e vítima - cujas entrelinhas tentavam encaixar o passado militar, cada vez mais, no passado (no tempo a ser superado), mesmo que as relações sociais, afetivas e identárias desenvolvidas no contexto militar permanecessem inscritas nas experiências do presente. Como exemplo, Beah narra quando Poppay (o homem encarregado do almoxarifado no Lar Benin) voltou do hospital após ser espancado pelos exmeninos soldado do centro:

[...] queríamos que os civis, como nos referíamos a toda a equipe, nos respeitassem como soldados capazes de machucá-los sem a menor compaixão. A maioria dos integrantes da equipe agia daquela maneira, voltava sorrindo depois que os machucávamos. Era como se tivessem feito um pacto para não desistirem de nós. Seus sorrisos nos faziam odiá-los ainda mais. (2015, p. 155).

O próprio modo de escrita com que Beah (agora adulto) descreve os eventos ocorridos no centro de reabilitação misturados com as memórias de quando habitava o espaço do soldado evidencia como as mudanças vão ocorrendo (des)continuamente e um ideal de infância vem sendo projetado nos contornos dos discursos da equipe. A culpa não é de vocês era a frase mais usada pelos adultos do centro quando lidavam com os ex-meninos soldado. Tal fala orientava o tom de passividade, não-responsabilização e vulnerabilidade em que os (ex-) meninos soldado eram envolvidos nos discursos de reintegração social dos adultos, sendo, primeiramente, entendidos como crianças - e, assim, vítimas do conflito - em necessidade de cuidados, tratamento médico e condução psicológica especializada.

No começo, Beah recebia essas palavras com ódio e fúria, pois desejava ser reconhecido, primeiramente, como soldado (mesmo sem a presença de sua arma) capaz de ser e de decidir no presente, ainda que sua condição etária o jogasse no mundo infantil. Estes dois mundos - o do termo criança e o do termo soldado novamente, confrontavam-se na produção de uma subjetividade específica para a agora ex-criança soldado, pois, quando o 'ex' entra em cena, noções de retorno a uma infância idealizada são mobilizadas por entre os discursos do 'estar traumatizada'.

A produção da categoria ex-criança soldado como traumatizada projeta um passado militar negativo que deve ser superado e, igualmente, um passado infantil positivo que deve ser lembrado com o propósito de ajudar na formação do sujeito resiliente. Logo, a posição de retorno da infância ideal e de suas temporalidades 
mostram como algo deve ser resgatado como positivo e contrapor o negativo do passado militar na busca da superação.

Tentava desesperadamente pensar na minha infância, mas não conseguia. As reminiscências da guerra tinham formado uma barreira que eu precisava quebrar para que conseguisse me lembrar de qualquer momento de minha vida anterior à guerra. (Beah, 2015, p. 165).

A possibilidade do retorno que conduze os dizeres de superação e esquecimentos restabelece, portanto, rupturas de passados: o positivo infantil (antes da guerra) e o negativo militar (durante o envolvimento da criança no grupo armado), reforçando a distância entre o mundo da infância moderna e o da guerra moderna.

Além disso, de outro lado, o passado infantil positivo busca ser retomado por entre os processos de reintegração social dos ex-meninos soldado no centro. Dessa maneira, os dois pilares do discurso do retorno para a ex-criança soldado - educação e família - também estavam presentes nas linhas da história de Beah por meio da promoção de uma escola informal onde os ex-meninos soldado do Lar Benin deveriam frequentar e, depois, pela reunificação familiar - a partir do encontro com seu tio e, posterior, convívio.

A primeira vez em que Beah contou a alguém sobre as suas experiências no grupo armado depois de entrar no Lar Benin - e de trazer o prefixo 'ex' no entendimento de sua posição temporal - foi para Esther (uma enfermeira do centro), após ela lhe perguntar qual seria a história por trás de suas cicatrizes nas pernas, com o intuito de prover um tratamento adequado. O ex-menino soldado, então, conta o evento de como balas e tiros marcaram seu corpo e descreve o motivo de sua narração: “ [...] então, contei toda a história de como tinha levado os tiros, não porque eu quisesse, mas pensei que se contasse a ela toda a terrível verdade sobre meus anos de guerra ela teria medo de mim e não faria mais perguntas. " $(2015, \mathrm{p}$. 172).

Nesse momento, reflito sobre o poder e a escolha da existência de uma narração na (re)produção da imagem de um sujeito, ou seja, pergunto-me aqui: por que contar uma história? Uma história de quem? Para quem? De que modo contála? Em que tom? Quando? Todas essas perguntas e algumas outras movimentam relações plurais de entendimentos que perpassam também os da categoria ex- 
criança soldado e de suas posições temporais, uma vez que, quando Beah traz essa história, sua percepção de si mesmo ainda no mundo do soldado, ele esperava uma reação de espanto e medo da enfermeira, embora sua posição infantil fosse, constantemente, frisada pela equipe. A reação da enfermeira veio para enfatizar o mundo da criança (civil) no singular traumatizada, repetindo a frase do pessoal do Lar: a culpa não é sua, suscitando sentimentos de raiva e arrependimento em Beah: " fiquei com raiva e me arrependi de ter contado a alguém, a uma civil, sobre minha experiência." (2015, p. 177).

A imagem do sujeito ex-menino soldado que conta esta história (na posição, para ele, de soldado) é inserida, paradoxalmente, nos discursos que o qualificam como criança traumatizada digna de compaixão. Suas falas e expectativas habitam um mundo discursivo incapaz de ser traduzido nas reações adultas que modelam o entendimento da categoria ex-criança soldado como passiva e traumatizada, sendo que, quando a palavra culpa é lançada como termo de decisão, possível de amenizar um peso adulto do conflito, confusas e ambíguas histórias são construídas para a posição de dúvida da ex-criança soldado.

Posteriormente, percebo que um momento decisivo na história de Beah, no que tange à tal posição incerta da ex-criança soldado, encontra-se na mudança de sua relação e reação com a frase a culpa não é sua, antes recebida com raiva. Sua percepção do "eu" como soldado começa a ser ressignificada, por isso, certos discursos ganham novos sentidos nas narrativas que formam sua categoria e seus comportamentos.

Apesar de eu ter ouvido aquela frase de todos os membros da equipe - e, francamente, sempre tinha odiado aquilo - naquele dia comecei a acreditar nela. Foi o tom verdadeiro na voz de Esther que fez aquilo finalmente começar a penetrar na minha cabeça e no meu coração. (Beah, 2015, p. 184).

Portanto, a partir desta mudança de reação e reconfiguração do passado militar, as posições temporais do ex-menino soldado e suas histórias se orientam nos encaminhamentos futuros pela possibilidade de projetar uma desejada estabilidade. O posterior convite feito pelo diretor do centro a Beah para ser portavoz do Lar Benin está relacionado com essa transformação de percepção, que traduz certas ações e atuações no mundo e, igualmente, com o poder de como/quando contar uma história de superação. Este convite veio logo após a apresentação de um 
show de talentos ocorrido no centro (para o pessoal da UNICEF, ONGs, Comissão Europeia, ONU), em que Beah escreveu e atuou em um pequeno esquete de hiphop sobre a redenção de um ex-menino soldado. Foi esta a primeira vez, desde a sua saída do grupo armado, que o termo ex-menino soldado aparece no livro e ele está em sintonia com o termo redenção.

Ao aceitar ser porta-voz do centro, Beah passa a narrar histórias sobre a reabilitação de ex-meninos soldado, apontando-o como exemplo de uma bemsucedida reintegração social. Percebo que a posição como ex-menino soldado redimido consegue contar outras histórias - com tons diferentes de quando se projetava a ex-criança soldado como traumatizada - que desenham um ideal de estabilidade e superação a partir dos entornos temporais do prefixo 'ex'. E, dessa forma, a imagem da ex-criança soldado, na figura do herói redimido, é aceita como formas de entendimento de sua categoria.

Nesse sentido, vejo que existe uma relação entre a produção de uma subjetividade específica e também de uma qualificação para a ex-criança soldado que é capaz de contar sua história, no caso, orientada para a estabilidade do futuro e da superação do passado militar traumático. Ou melhor, vejo que as histórias da ex-criança soldado traumatizada são trazidas em silêncio por meio de certos ideais de ordem, estabilidade e, principalmente, de ser criança, traduzíveis e audíveis somente quando a ex-criança soldado redimida entende sua já pré-estabelecida posição.

A posição temporal de Beah como ex-menino soldado é colocada em dúvida novamente com a chegada do conflito armado em Freetown, onde ele estava morando com a família de seu tio, pois, marcado por fins e (re)começos, o descompasso entre o seu passado militar (quando o prefixo 'ex' entra em cena) e a duração do conflito no país trouxeram novas relações temporais, sociais, identitária e emocionais junto às configurações da guerra e de suas histórias. Essas (des)continuidades e reviravoltas entre a categoria ex-criança soldado e o conflito armado, nessa história, marcam interconexões ambíguas e paradoxais entre o mundo da infância moderna e o do conflito armado moderno e a incompatibilidade de projetá-los juntos no presente.

Naquele momento, percebendo-se como criança e civil, Beah traz para si um novo dilema e conta: 
Eu tinha que ir embora, porque temia que, se ficasse em Freetown por mais tempo, acabaria voltando a ser soldado ou, caso me recusasse, meus antigos companheiros de exército me matariam. Alguns amigos que tinham passado pela reabilitação comigo já tinham voltado ao exército. (2015, p. 232).

Assim, sua jornada de fuga do conflito (re)começa, junto de certas rupturas e acasos, com outra cara e outras marcas. Os desenhos temporais difusos da categoria ex-criança soldado permanece inscrito nessas experiências do (pós-) conflito, por isso, a história e trajetória de Beah - trazida como memórias de um adulto que narra sua sobrevivência - traduz essas linhas temporais incertas da categoria ex-criança soldado como interrogação. Narrada por entre um passado militar negativo e um futuro estável adulto, a ex-criança soldado permanece em muitas temporalidades do (pós-) conflito, nas mais variadas estórias e histórias. Nesta escrita literária, analisei, a partir da seleção de alguns eventos, como a categoria ex-criança soldado é trazida discretamente e transparece ambíguas relações temporais estabelecidas entre a infância moderna e o (pós-) conflito moderno.

\section{5 \\ Os três em um e o um em muitos: questionando a categoria ex-criança soldado}

Estou aqui no sopé da estrada, à espera que alguém me leve. Um qualquer, tanto faz. Basta que passe e me leve. É meu sonho antigo: sair deste despovoado, alcançar o longe. Até já cansei este sonho. Meu tio sempre me avisou: não durma perto da estrada que as poeiras irão sujar seus sonhos. E aconteceu. Mas eu, nem se acredita, eu sempre gostei de poeira porque me traz ilusão dos caminhos que não conheço.

Mia Couto, Na berma de nenhuma estrada e outros contos

Nesta parte, reconheço a dificuldade em 'montar' uma junção ou combinação dos diferentes tipos de escritas e textos que modelam a categoria ex-criança soldado, pois creio que essas combinações são como fissuras de incertezas e interrogações, instáveis e difíceis de serem traduzidas em falas que não sejam de dúvidas. Por isso, neste momento, pretendo mostrar quais são os meus 
questionamentos e interrogações sobre, principalmente, essas fissuras temporais da categoria (ex-) crianças soldado dentro desses discursos da resiliência (junto com os do trauma) - que, igualmente, confundem-se de texto para texto e de olhar para olhar.

Desse modo, começo me perguntando: quem pode contar uma história de superação? Nas entrelinhas dos discursos da resiliência aqui apresentados, plurais entre si, o ser (ex-criança soldado) resiliente se descreve como aquele sujeito, que tendo superado o envolvimento militar, toma controle (racional) de sua história e, assim, é capaz de narrar sua trajetória de luta, dificuldades, sobrevivência e superações. Nesse viés, a ex-criança soldado resiliente, neste sentido, como a imagem do herói redimido, orbita em quais posições temporais? Percebo que são múltiplas temporalidades que marcam as difusas relações e posições entre a (ex-) criança soldado, o grupo armado e o (pós-) conflito. Todavia, o prefixo 'ex', nos discursos da resiliência, traz tanto um passado militar (traumático) a ser superado quanto um futuro estável a ser desejado. O entendimento de superação aqui está relacionado com uma certa (re)configuração do passado militar por parte da criança, ou melhor, as histórias das ex-crianças soldado só conseguem ser traduzidas - no internacional adulto - quando os seus dizerem entram em harmonia com sua posição, primeiramente, de criança e seu passado militar como tempo acabado e imutável.

Sob este prisma, a superação como resiliência se apresenta através da capacidade de projetar o envolvimento militar no passado, naquele tempo tido como finito e acabado, e, igualmente, de se apoiar na esperança de um futuro melhor. Conforme Fasolt (2004) afirma, essas divisões temporais são social e historicamente produzidas, sendo o passado construído como o tempo ausente das relações estabelecidas no presente e tido como um momento acabado e imutável.

Ser ex-criança soldado resiliente, neste caso, envolve dois movimentos específicos, interligados, ambíguos e indiferenciáveis: 1) uma certa superação do passado militar (seja pela ideia de não-culpa ou por caracterizá-lo como, primeiramente, negativo, porém passível de trazer algum aprendizado); 2) certos esquecimentos que deixam rastros. Trago esses esquecimentos como temporais e subjetivos, capazes de se juntar na reflexão artística que a leitura de Beah me proporcionou, de primeiro momento, e na qual pretendo me aprofundar mais adiante. Os esquecimentos temporais e subjetivos envolvem tanto os processos de 
tradução das histórias e estórias das ex-crianças soldado, quanto a produção da subjetividade civil (em oposição ao soldado) e também a sua posição de espera no presente; abraçando, assim, as tentativas de estabilizar o sentido da categoria junto aos traços e laços temporais e subjetivos que permanecem nas ambíguas e plurais vivências das ex-criança soldado.

Como os discursos do tratamento do trauma e da resiliência colocam o envolvimento militar da criança no passado? Como é demarcado este passado? Neste momento, reproduzo uma história sobre duas ex-crianças soldado de Moçambique contada no artigo de Magid e Boothby (2013):

Both Vasco and Israel were in the ranks of Renamo as children; however their outcomes varied drastically 16 years after demobilization. The outcome of Vasco, a Renamo youth leader, was negative, and he was never able to fully reintegrate into society; he remained uncontrollably violent and drank heavily. Although he had been married, his wife left him because he was too aggressive. On the other hand, Israel, 12 years of age at the time of his abduction by Renamo, is a success story. Israel was rehabilitated, married with two children, and praised as a model neighbor and father. Why did Israel become a productive member of society, while Vasco remained violent years later? What distinguishes these two boys, both of whom served as child soldiers with Renamo? (p. 41).

Nesse espaço enunciativo, considero que as (des)continuidades entre os termos histórias e estórias se expressam nas aparências de um discurso tido como 'verdadeiro' em contraposição a um outro construído como 'ficcional', ou melhor, percebo que as distinções entre história e estória se mostram nas ambiguidades do ser resiliente. Enquanto a história é entendida como a narração de fatos notável e como a ciência autorizada a estudar o passado - seja do ser humano, seja das construções sociais - a estória pertence à narrativa romanceada e ficcional e consegue se acomodar nos espaços infantis, trazendo outras noções temporais sobre superação. Assim sendo, reconheço que histórias e estórias são termos e momentos que se confundem, misturam-se e não se acomodam.

Muitas outras estórias permeiam essas duas histórias dos ex-meninos soldado, posto que, entre quem é ou não um sujeito resiliente, existem ideais de estabilidade, socialização e ordem social que fazem uma história ser 'de sucesso' e outras não. Em contraposição à superação, as atitudes e comportamentos das ex-crianças soldado e depois do adulto que permanecem ligados ao mundo da violência (e, de certa forma, ao conflito armado moderno) as projetam como não resilientes, como não capazes de deixar o envolvimento militar no passado e seguir em frente, porque, 
os discursos da resiliência para a ex-criança soldado busca se manter em tons futuros, na esperança da superação.

Nesse sentido, percebo que ser resiliente vem com certas respostas e parece traduzir específicas histórias e relações sociais para ex-criança soldado, perpassando visões de subjetividade, cultura, comunidade, e, principalmente, de tempo. Essa condição temporal se apresenta junto com a forma de compreender como certas situações e comportamentos são produzidos como normais e outros como desviantes, ou melhor, como a articulação das durações e transições da (ex-) criança soldado e o (pós-) conflito são (re)contadas por entre rupturas e linearidade em que o sujeito traumatizado deve (re)interpretar eventos e localizá-los a fim de superá-los.

Entretanto, de outro lado, aqui questiono: o discurso da resiliência para a excriança soldado também não poderia trazer a resistência e a persistência do passado militar que se afirma continuamente no presente? O trauma, como esse movimento de repetição, não seria uma marca de resiliência como capacidade de se autoconhecer? Os discursos da resiliência e do trauma para ex-crianças soldado não poderiam produzir temporalidades não-lineares e interruptivas capazes de inscrever o passado militar no presente e, assim, projetar um outro futuro?

$\mathrm{O}$ artigo de Zack-Williams traz a resiliência também como enfrentamento no presente e resistência às condições sociais, e o guia da IASC constrói um discurso de resiliência capaz de aparecer no antes, no durante e no após o conflito armado. Isso mostra como os dizeres e discursos da resiliência são plurais e ambíguos, envolvendo os desenhos temporais das (ex-) crianças soldado em traços difusos por entre as durações e transições do (pós-) conflito. Consequentemente, mesmo que o prefixo temporal 'ex' pareça, de primeiro momento, firmar uma estabilidade temporal entre o passado militar e o futuro do adulto, a posição temporal da excriança soldado é incerta e duvidosa, capaz de "misturar" os discursos do trauma e da resiliência por entre as múltiplas temporalidades de suas histórias e estórias.

Agu, agora ex-menino soldado, encontra-se em um centro de reabilitação junto ao pessoal de ajuda das Nações Unidas. Suas palavras finais destinadas à moça do abrigo, Amy, são capazes de traduzir difusas percepções e presenças das temporalidades do (pós-) conflito. Após algumas insistências da moça no intuito de conhecer mais sobre o seu envolvimento militar, Agu diz: 
I saw terrible things and I did terrible things. So if I am talking to you, it will make me sad [...] And it will make you, too, sad. In this life [...] I just want to be happy in this life. If I am telling this to you, you will think that I am sort of beast or devil. I am all of these things [...] but I also having mother, father, brother and sister once. They loved me. (Beasts of no Nation, 2015)

Esse discurso encerra os diálogos do filme e retoma, em silêncio, as ações e experiências de Agu no grupo armado, que, ainda que não sejam faladas, permanecem nos contornos temporais de sua identidade como soldado e criança. Ao mesmo tempo, existe um retorno ao passado infantil, quando o menino Agu vivia junto a sua família, e a projeção do ser criança retorna junto ao 'ex'. A divisão difusa entre a infância moderna e o conflito armado moderno, nessa fala de Agu, evidencia o quanto as relações entre o passado militar e o futuro de felicidade estão ligados por outras temporalidades e subjetividades que permeiam as nossas miradas à categoria (ex-) criança soldado e ao (pós-) conflito. Elas representam rastros ambíguos e plurais que vêm com a possibilidade de deixar o não-dito permanecer por entre o já dito da categoria ex-criança soldado.

Pautada nesse quadro, a construção da resiliência como paradigma em oposição ao trauma revela um certo caminho de se projetar o envolvimento militar da criança e também de colocá-lo no passado, como aquele tempo que necessita ser superado. Contudo, as relações entre os discursos do trauma e os da resiliência sobre a categoria ex-criança soldado, plurais entre si, podem ser traduzidas também por ambiguidades, interrupções, complementaridade e (des)continuidades que orbitam na produção de uma história adulta sobre o confuso distanciamento entre a infância moderna e a guerra moderna.

Assim, quando Agu conta sua história, sem contá-la, os silêncios das fissuras entre os discursos do trauma e da resiliência se misturam na ambígua e incerta posição temporal do ex-menino soldado incapaz de estabelecer um entendimento homogêneo para seu passado militar, ou ainda, mostrando a dificuldade de qualificar a categoria ex-criança soldado como traumatizada ou resiliente.

[...] is that trauma seems to be much more than a pathology, or the simple illness of a wounded psyche: it is always the story of a wound that cries out, that addresses us in the attempt to tell us of a reality or truth that is not otherwise available. This truth, in its delayed appearance and its belated address, cannot be linked only to what is known, but also to what remains unknown in our very actions and our language. (Caruth, 1996, p. 4). 
Nas palavras de Emmanuel Jal, sigo minhas reflexões: "Now I pray that is when I gain, when I pray to you, do you maintain? When I pray to you, do you maintain?" (Jal, 2008). Essas esperanças mobilizam expectativas de superações e estabilidades, desenhando a posição temporal da ex-criança soldado como incerta. Um questionamento que permanece no decorrer da leitura e da análise desses três documentos - cada qual com seu estilo e escrita - vem junto àquela foto do menino com a arma e com as asas de borboleta (Figura1) - o que machuca mais: as asas ou a arma?

\section{6}

\section{Concluindo: as asas nas tempestades}

Neste momento, pretendo retomar algumas das minhas principais reflexões sobre os discursos do trauma e da resiliência que (re)produzem a categoria excriança soldado e seus desenhos temporais difusos. Descrita por entre um passado militar negativo e um futuro adulto desejável, a categoria ex-criança soldado e seus contrastes traduzem subjetividades e histórias passíveis de serem contadas, enquanto outras permanecem em silêncio. No entanto, esses silêncios são também possibilidades do não-dito, passíveis de serem mostradas na análise do estético, que (de)compõe as temporalidades do (pós-) conflito e de suas relações com as (ex-) crianças soldado.

Além disso, os discursos que projetam as ex-crianças soldado ora como traumatizadas ora como resilientes se apoiam em uma divisão linear do tempo, em que passado e futuro são bem delimitados. Porém, as diversas experiências e vivências das (ex-) crianças soldado mostram quão (des)contínuas se apresentam suas posições temporais e as configurações do seu passado militar, uma vez que as relações e interconexões entre os discursos do trauma e da resiliência se dão além de apenas oposições, estando também em deslocamentos, sobreposição, ambiguidades, complementaridades e simultaneidade, capazes de refletir a posição incômoda da ex-criança soldado no presente e as múltiplas temporalidade que envolvem seus movimentos no mundo.

Ao me propor discutir e refletir sobre as construções da categoria ex-criança soldado por entre o 'estar traumatizada' e o 'ser resiliente' que projetam o imaginário internacional moderno sobre a posição temporal do sujeito narrador, 
busco, igualmente, pensar nos esquecimentos temporais e subjetivos que traduzem esta posição da ex-criança soldado como resiliente.

O sujeito (ex-criança soldado) resiliente, nos discursos analisados, torna-se o único capaz de narrar uma história de superação e vitória perante o passado militar, que não mais interfere no momento presente e, assim, também na formação do adulto 'saudável'. Suas histórias estão em consonância com o ideal de superação e retorno à normalidade, representando o distanciamento entre o mundo da infância moderna e o do conflito moderno em tons futuros. A esperança e o senso de futuro guiam as narrativas da resiliência para a ex-criança soldado que, em realidade, são temporalidades bagunçadas e experiências ambíguas.

"Storms only come for a while. Then after a while, they'll be gone. Blessed, blessed." (Jal, 2008). 


\section{4 \\ No traço da espera: a produção do presente para a categoria ex-criança soldado}

\section{1 Introdução}

Um capítulo em espera, aguardando seu momento de ser leitura e análise. Um traço do presente que, ao mesmo tempo, envolve, em conjunto, o passado (dos capítulos anteriores) e me prepara para os futuros rumos últimos deste trabalho. Este capítulo mostra como a posição incômoda da categoria ex-criança soldado no presente molda uma imagem duvidosa do sujeito, porquanto, estando em interrogação, a categoria ex-criança soldado orienta tanto a tida posição de espera do ser criança - aguardando para se tornar um adulto - quanto a esperança de superação do passado militar e do ser resiliente.

Assim, a posição de espera da ex-criança soldado está associada com o aguardo da criança que ainda não é adulto e com a esperança de que, mesmo após um passado traumático, ela seja capaz de lidar com as dificuldades e se sair bem. Desse modo, pensando-se a partir do discurso da Psicologia do Desenvolvimento; para a qual uma 'boa infância' é pré-requisito para uma 'boa adultez' e também o contrário (Qvortrup, 2004), o passado militar da ex-criança soldado coloca em dúvida sua 'história de sucesso'. Nesse sentido, retomar a infância ideal busca, de certa forma, tornar cabível um discurso de superação, estabilidade e reconciliação que orienta os desenhos temporais do ser resiliente no pós-conflito.

A 'boa adultez' está com seus alicerces postos nas desenvolturas do ser resiliente, visto que a resiliência afirma a capacidade de superação e adaptação da ex-criança soldado perante seu passado militar e, consequentemente, a possibilidade de projetar um futuro estável por meio da (re)configuração do envolvimento militar. Trago a tradução de tal (re)configuração por entre certos esquecimentos subjetivos e temporais capazes de ajeitar a posição do sujeito narrador da história de superação em uma relação temporal linear.

Passado e futuro parecem bem definidos nas dinâmicas da ex-criança soldado resiliente, entretanto, consoante tenho mostrado, as relações temporais difusas desenhadas entre as (ex-) crianças soldado e o (pós-) conflito se embaralham em suas histórias e estórias no presente. 
Questionando o discurso presente na Psicologia do Desenvolvimento ('infância ruim' leva à 'adultez ruim'), Mccallin (2009) analisa como a relação entre a resiliência e o desenvolvimento infantil pode ser útil para compreender o modo de amenizar os fatores de riscos em ambientes de insegurança e instabilidade que afetam o desenvolvimento das crianças e, igualmente, focar-se nos fatores positivos de adaptação. Desse modo, ao invés de se apoiar em um modelo de déficit que prevê perspectivas negativas para as crianças, a resiliência vem como paradigma capaz de afirmar a capacidade de algumas pessoas em ficarem bem, mesmo depois de uma experiência de extrema adversidade. Conforme se observa neste excerto:

$[\ldots]$ it shifts the emphasis away from more deterministic approaches that focus on risks and adversity, predicting only negative outcomes from people's experience, and which portray them as helpless victims, rather than people with the capacity to deal with their adversities. (Mccallin, 2013, p. 67).

Sob a ótica da resiliência, as ex-criança soldado são projetadas como sujeitos capazes de superar as dificuldades do passado militar e, portanto, de se saírem bem na vida e construírem uma 'história de sucesso'. Além disso, os tons futuros que norteiam as concepções de felicidade, estabilidade e demais visões positivas destinadas às ex-crianças soldado refletem também a possibilidade da existência do ser resiliente na modelagem do discurso do ser e tornar-se, que guia os estudos sobre a infância e a criança.

Neste capítulo, portanto, procuro trazer a produção do ser criança entre o 'ser' (human being) e o 'tornar-se' (human becoming), passando pelo discurso da criança em posição de espera para entrar no mundo adulto e também pelos questionamentos e críticas desta visão binária - human being vs. human becoming - presente dos Estudos da Infância. Essas críticas orbitam em torno da análise temporal da infância moderna e questionam a linear representação do tempo de crescimento e desenvolvimento que perpassa a infância e a adultez. Junto a isso, as ambíguas e plurais relações entre os discursos do trauma e da resiliência também entram em cena nos contornos temporais que mobilizam o prefixo 'ex'; porém, quando postas em contradição, o 'estar traumatizada' e 'ser resiliente' projetam subjetividades e temporalidades específicas de se pensar a categoria ex-criança soldado entre superação e esquecimentos. 
Durante os ritmos lentos e acelerados da música Warchild de Emmanuel Jal, a narrativa de um passado militar vai se misturando com tons presentes na produção do sujeito ex-criança soldado capaz de contar sua história. "I am a war child (I'm gonna get glory glory glory glory). I am a war child. I believe I've survived for a reason to tell my story, to touch lives (touch lives, touch lives touch lives, touch lives)." (Jal, 2008).

O poder de narrar/cantar uma história de superação está relacionado a essas construções da categoria ex-criança soldado ora como traumatizadas, ora como resilientes, que permanece na tradução de seu futuro como adulto e a inscrevem no sentido da esperança do ser que conjuga o verbo. Averigua-se que, na posição do tornar-se, a ex-criança soldado mobiliza o futuro do ser adulto junto com o do ser resiliente (em seu sentido ideal), quando a capacidade, autonomia e estabilidade alcançam sua alocação temporal ideal. São histórias e estórias impossíveis de serem fixadas na linearidade temporal moderna e na relação, essencialmente, de oposição entre os discursos do trauma e da resiliência.

\section{2 \\ A posição incômoda da ex-criança soldado no presente}

At the end of the war we wanted peace but there were no jobs and we did not have means of supporting our families. In such a situation, why not remain a soldier? At least it's a way of earning some small amount of money. [Ex-menino soldado, Afeganistão]. (Wessells, 2006, p. 155).

Além desta pergunta, muitas outras permanecem durante o momento do prefixo temporal 'ex'. Nesta alocação de interrogação, as respostas apresentadas pelo discurso do retorno, em contrapartida, afirmam a necessidade de trazer o ser criança (no singular), ao invés do soldado, nos contornos das histórias de superação.

Dessa maneira, deslizando entre os dois sentidos do termo espera na língua portuguesa - aguardo e esperança - a categoria ex-criança soldado espera um momento para ser (adulto e, ao mesmo tempo, resiliente). Este 'ser' delimita o pensar sobre a ex-criança soldado entre passado, presente e futuro, dividindo os eventos e momentos de suas experiências e os alocando em determinados espaços temporais bem estabelecidos.

O discurso do ser e tornar-se e, principalmente, as críticas destinadas ao antagonismo de sua relação ajudaram a projetar minha argumentação sobre os 
desenhos temporais difusos da ex-criança soldado, tanto pelo questionamento do discurso temporal linear, quanto pela problematização da visão, essencialmente, opositora entre os discursos do trauma e da resiliência que formam sua categoria. Considero que essa análise abre espaços e tempos para questionar também outros binarismos opositores, como exemplo: conflito e paz; infância e adultez; público e privado entre outros, igualmente, capazes de simplificar as múltiplas temporalidades que se emaranham na (re)produção de um evento.

Nesta parte, portanto, pretendo expor o discurso temporal da infância moderna e a projeção da criança que espera, juntamente com a produção das alternativas críticas de se refletir sobre o tempo da infância e da criança além da dicotomia do ser e tornar-se que me proporcionaram reflexões sobre a posição da ex-criança soldado no presente e seus desenhos temporais difusos.

\subsection{1 \\ A infância temporal moderna: a criança que espera}

Retomando o discurso da posição temporal da criança e o tempo da infância, neste momento, busco relacionar como a construção da categoria ex-criança soldado passa por entre a concepção linear do desenvolvimento infantil que, igualmente, perpassa as passagens e incertezas do tempo social e das temporalidades entre infância e adultez. No discurso tradicional do desenvolvimento infantil, a criança espera para adentrar e pertencer a ela, preparando-se no momento presente com vistas ao futuro sendo este futuro que a aguarda, capaz de trazer a capacidade, autonomia, estabilidade e participação social referentes à sua posição como posterior adulto. Sendo assim, a posição no presente que envolve as trajetórias entre a infância e a adultez e entre a criança soldado, a ex-criança soldado e o adulto consegue ser traduzida, dentro dos discursos dominantes da Psicologia do Desenvolvimento e também o discurso do retorno, como em uma condição de espera.

Assim como Qvortrup (2004), percebo que, dentre estas narrativas, o destino das crianças é permanecer esperando. Elas esperam para serem adultas. Desse modo, a infância é trazida como uma fase transitória e de preparação, cujo ideal está na modelagem do indivíduo adulto que, no futuro, poderá participar e integrar a sociedade. "Thus childhood is spoken about as: a 'becoming'; tabula rasa; laying 
down the foundations; shaping the individual; taking on; growing up; preparation; inadequacy; inexperience; immaturity, and so on. "(Jenks, 2005, p. 8).

Neste sentido, destacando a diferença construída entre a criança e o adulto como categorias sociais distintas, Lee (2001) analisa como e por que, na modernidade, a categoria 'humano' foi dividida entre adulto e criança. Qvortrup, no seu livro Childhood as a special phenomenon: an introduction to a series of national reports (1991), percebeu essa diferenciação e, criticamente, endereçou-a como entre o adulto (human being) e a criança (human becoming). $\mathrm{O}$ ser (human being) estaria relacionado com um estágio de estabilidade, competência, independência e autocontrole, enquanto o tornar-se (human becoming) era referido, em contrapartida, como mutável, dependente e incompleto. Segundo Lee, além disso, essa divisão seguiu o crescimento histórico de duas figuras: o "adulto padrão" como o ser humano independente e o "estágio de desenvolvimento" como modelo de relações apropriadas entre Estados e suas populações em que as crianças são projetas como human becomings. (2001, p. 5).

Portanto, a produção da diferenciação entre crianças e adultos está relacionada com as circunstâncias que tornaram possível, primeiramente, pensar nos adultos como seres humanos estáveis e completos. Entretanto, ao mesmo tempo, de acordo com Lee, as condições de nossa 'era da incerteza', no começo do século XXI, trouxeram mudanças econômicas e culturais que questionaram a natureza da adultez e o papel estável do sujeito adulto. Ponto este que procurarei refletir no próximo capítulo.

Nos discursos, ainda hoje, dominantes no campo da infância e das crianças, a infância somente se faz conhecer em comparação com a adultez, entendendo todo e qualquer movimento da criança em termos de seu processo de desenvolvimento até o sujeito adulto. Destarte, “children's lives and activities in the present are still envisaged, in the main, as a preparation for the future.” (Lee, 2001, p.8, itálico no original). Nessa perspectiva, a adultez foi estabelecida como um ponto fixo e estável capaz de nortear as relações estabelecidas na infância, sendo esta projetada como uma fase temporária em que a instabilidade, incompletude e imprevisibilidade marcam a posição das crianças no presente como dependentes e em necessidade de regulação.

O crescer, então, é representado como o processo em que a criança se transforma em seu oposto, um adulto, e cruza a fronteira entre o human becoming 
e human being. Quando o ser humano entra em cena, atributos como responsabilidade, autonomia, participação social, maturidade e competência compõem o "adulto padrão" em sua alcançada estabilidade seja no mundo econômico, na vida afetiva e nas relações sociais. Porém, conforme Lee (2001), muitas dessas construídas certezas ficcionais da adultez começam a ruir com as mudanças sociais e culturais de nosso século, e a posição de autoridade e estabilidade do adulto passa a ser posta em dúvida.

As imagens, primeiro, da adultez como o fim da jornada e depois dos adultos, aqueles que chegaram a esta linha final, são essenciais na manutenção da autoridade e do modelo "adulto padrão", o qual tem o direito e dever de tomar conta das crianças. Essas relações de poder e de autoridade entre adulto e criança estão inscritas também nas alocações temporais da criança no singular que perpassa o discurso do retorno para a ex-criança soldado como a criança desviante que necessita retomar o desenvolvimento ideal da infância para ter uma 'boa adultez'.

Esse discurso do retorno, junto aqui com os do trauma e da resiliência que formam a sua categoria, acaba alimentando a visão de maior flexibilidade e maleabilidade da criança em comparação ao adulto, pois, apresentando-se como um ser humano em formação, a criança é tida como incompleta e mutável e, consequentemente, como maior capacidade de superar o passado traumático, de ser resiliente e de construir uma 'história de sucesso'.

Todavia, percebo que esta ideia da criança como tabula rasa causa, simultaneamente, dois movimentos ambíguos para a categoria ex-criança soldado: primeiro, a possibilidade de projetar a ex-criança soldado como mais capaz de ser resiliente, por estar 'em formação', nesse sentido, o envolvimento militar consegue ser melhor ressignificado e ficar no passado. Segundo, traz a necessidade de controle e regulação das ex-crianças soldado, as quais, por sua imprevisibilidade, precisam ser guiadas e controladas com o objetivo de retomar o processo ideal de desenvolvimento e terem "a infância de volta". O exposto sugere que, se não forem 'salvas' adequadamente das 'guaras do conflito', a estabilização e a fixação de comportamentos não-relacionadas à infância moderna e a seu estágio de desenvolvimento levariam a uma 'adultez ruim' com um adulto conturbado. Logo, percebo que os dois movimentos envolvem respostas e recursos adultos destinados à reintegração da ex-criança soldado no discurso do retorno capazes de serem oferecidos pelo internacional. 
De outro lado, ao invés de olhar as crianças como adultos em formação, Qvortrup (2009), em suas argumentações, assevera que as crianças são e devem ser encaradas como participantes da sociedade, tanto porque elas possuem um papel na divisão do trabalho - seja em termos de estar na escola, que está em relação e não distante do trabalho da sociedade como um todo - quanto por conta da influência da infância nos planos e projetos não somente dos pais, mas também, do mundo econômico e social.

Além disso, o autor percebe a infância em termos estruturais, como sem começo e nem fim temporal; isto é, ao invés de ser entendida como um período, a infância é projetada como uma forma permanente de qualquer estrutura geracional. Dessa maneira, a infância é permanência em termos de estrutura e também, é mudança constante em relação ao espaço social onde as crianças levam suas vidas. "Childhood is there as a social space to receive any child born and to include the child - for better or for worse - throughout his or her childhood period." (Qvortrup, 2009, p. 26).

Aqui destaco a importância em diferenciar os conceitos de infância e de criança, consoante apresentei no capítulo segundo, visto que na visão de James (2004), esses termos devem ser distinguidos a fim de evitar generalizações sob a ótica do desenvolvimento etário, capaz de camuflar as outras maneiras plurais e culturais de se pensarem as infâncias. "It is as if children's growing-upness was the only interesting aspect of children's lives!” (James, 2004, p. 33). Endossando o mencionado, o paradigma dos Estudos da Infância afirma que as experiências das crianças sobre o crescer são mediadas culturalmente, por isso, o termo infância, ao invés de representar a descrição de uma fase universal de desenvolvimento, é visto como plural e aberto para interpretações. Ademais, as crianças são percebidas como construtoras de suas próprias infâncias e fazem parte da formação do seu mundo social, tendo agência para moldar a forma como a infância se desenvolve nas experiências diárias do seu contexto político, social e econômico.

Levando em consideração o apresentado, os Estudos da Infância, como vertente crítica ao discurso do desenvolvimento infantil, reconhece a criança também como human being, como ser humano capaz de influenciar a sua realidade social e de fazer a sua participação um marco importante no presente, olhando a criança como ser no presente e não, somente, orientada para o futuro do adulto. (James, 2004). Contudo, percebo que, para transparecer os difusos desenhos 
temporais da categoria ex-criança soldado, é necessário ir além da visão dicotômica entre o ser e o tornar-se, que acaba migrando de um enfoque a outro e simplificando as ambiguidades das temporalidades que se emaranham na construção das histórias e estórias das ex-crianças soldado e de suas relações com o (pós-) conflito.

\subsection{2 \\ Para além do binarismo sere tornar-se: (des)continuidades temporais}

A infância não é um tempo, não é uma idade, uma colecção de memórias. A infância é quando ainda não é demasiado tarde. É quando estamos disponíveis para nos surpreendermos, para nos deixarmos encantar. Quase tudo se adquire nesse tempo em que aprendemos o próprio sentimento do Tempo.

Mia Couto, E se Obama fosse africano?

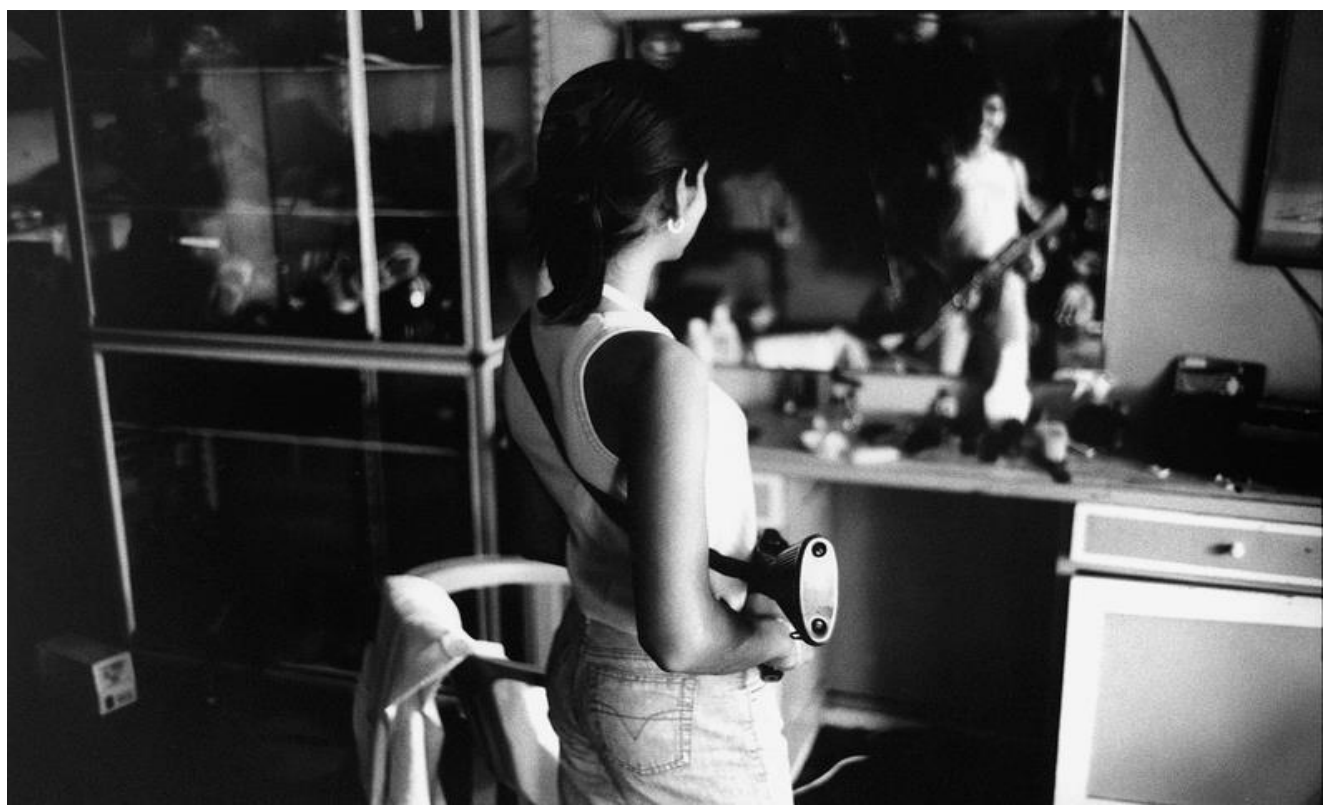

Figura 6: Foto de uma menina soldado encontrada no livro Child Soldiers de Leora Kahn (ed.), 2008. ${ }^{22}$

Os difusos reflexos das (ex-) crianças soldado permanecem incertos no presente; entre a arma e o sorriso, os dois mundos - o da infância moderna e o do conflito armado moderno - mostram as suas ambiguidades temporais. O ser (ex-)

22 Disponível em: < http://www.powerhousebooks.com/books/child-soldiers/> Acesso em: 10 fev. 2018. 
menina soldado transpõe ainda relações outras com o conflito armado moderno, as quais envolvem reflexos corporais e sociais específicos e diferentes daqueles projetados aos (ex-) meninos soldado. Por entre os variados reflexos que se intercruzam nessa foto, pretendo mobilizar aqui os difusos desenhos temporais da categoria (ex-) criança soldado capazes de trazer o passado militar nas (des)continuidade do ser no presente e que, igualmente, envolvem os processos do tornar-se. Desse modo, nesta parte, procuro bagunçar a visão binária da relação entre human being e human becoming, visão esta que modela o discurso da criança que espera e, assim, também questionar a linear disposição temporal em que as histórias das ex-crianças soldado são construídas.

Assim sendo, começando com essa foto, penso em trazer como as ambiguidades temporais (de)formam a categoria (ex-) criança soldado e suas histórias e estórias. Ademais, pretendo refletir sobre como nossa mirada à noção temporal está vinculada com a nossa posição como adulto no presente. Alicerçandome, para tanto, na pesquisadora da área de educação da State University of New York que realizou um estudo acerca das impressões e impactos que as fotos das (ex-) crianças soldado traziam ao público ocidental adulto.

Tais fotos foram selecionadas do livro Child Soldiers de 2008, editado por Leora Kahn, fundadora da organização Proof (mídia para a justiça social) e publicado pela powerHouse Books. O livro, dividido por país, contém, em sua maioria, fotos coloridas de (ex-) crianças soldado da Colômbia, Guatemala, El Salvador, República Democrática do Congo, Sudão, Uganda, Libéria, Serra Leoa, Nepal, Sri Lanka, Bruma, Afeganistão, Palestina e Iraque, sendo que trinta e quatro fotojornalistas contribuíram com suas imagens para a produção deste livro. (Sharkey, 2012).

As imagens foram mostradas durante entrevistas conduzidas com adultos entre trinta a sessenta e seis anos, no intuito de apresentar como o entendimento sobre as (ex-) crianças soldado existe, em parte, por conta dessas fotografias que transmitem certas emoções e antecipam respostas afetivas no observador adulto. Todos os adultos participantes possuíam ensino superior completo e viviam em uma cidade canadense de tamanho mediano. Durante as entrevistas, Sharkey pediu para as pessoas descreverem o que viam, o que notavam em específico, quais emoções as imagens lhes causavam e como pensavam sobre a condição daquelas crianças. (2012, p. 262). 
Segundo a análise de Sharkey,

[...] all of the participants responded to the photos with a mixture of anger, sadness, and with comments about how imagination-defying the lives of child soldiers must be, and with the following words and questions hanging in the air: Why? How can this be? What can be done? What about the rest of the lives of these kids? (2012, p. 263, itálico meu).

Essas impressões e reações conduzem a mais perguntas e incertezas sobre fatos e rastros que não são visíveis nas fotos, histórias que permanecem em silêncio por entre as imagens e os textos. As perguntas que norteiam tal visão para as imagens das (ex-) crianças soldado estão envolvidas em um olhar específico sobre a posição temporal do sujeito adulto. Ou seja, em particular, destaco a última pergunta e o modo como remete aos contornos temporais da criança em formação. Assim, a posição temporal do adulto que olha a criança, neste caso, para a (ex-) criança soldado, relaciona-se com emoções e percepções sobre um passado e um futuro: o da criança que um dia fora e do adulto que ela está se tornando.

Conrad (2011), corrobora esse cenário ao expor que, dada a importância do tempo na significação da infância para os adultos, reconhecer as interpretações das temporalidades e das subjetividades vindas das crianças torna-se um desafio e uma dificuldade, uma vez que a percepção do adulto em relação à vida das crianças no presente está sempre direcionada à lembrança de um passado e à esperança de um futuro. Estando em retrospectiva e continuidade, portanto, a mirada do sujeito adulto mostra uma percepção linear do tempo que marca, igualmente, o ideal temporal do discurso do retorno para (ex-) criança soldado. Desse modo, neste momento, procuro trazer algumas das propostas alternativas à visão dicotômica do ser e tornar-se, propostas essas capazes de questionar a linearidade temporal do discurso do desenvolvimento infantil e da criança que espera, envolvendo as múltiplas temporalidades da infância e da adultez.

Em um primeiro momento, Uprichard (2008) propõe pensar tanto a infância quanto as crianças sempre e necessariamente como ambos: ser e tornar-se. Nesse sentido, ao invés de perceber a criança ora como human being (ator social que constrói ativamente sua infância) ora como human becoming (o adulto em formação), é possível reconhecê-la como ambos: o ser e o tornar-se atuam de maneira complementar, já que, conforme a autora, nenhuma das abordagens 
isoladas consegue englobar, satisfatoriamente, as temporalidades da criança e da infância.

Dessa forma, a proposta é incorporar o presente e o futuro da criança com a finalidade de equilibrar suas importâncias nos discursos da infância e da adultez, problematizando a visão binária do 'ou'. Além disso, a infância como evento temporal e tratando a criança como human being e human becoming amplia a noção de agência, e as crianças são projetadas como indivíduos capazes de construir suas vidas no presente e no futuro.

Hence, conceptualising children as 'being and becomings' is not only constructive in terms of explicitly addressing the ageing process within childhood itself, it also reflects the ways that children themselves see themselves and their changing world within which they are necessarily situated. (Uprichard, 2008, p. 310).

Sob outro aspecto, Hanson (2017), com o propósito de entender as crianças individual e coletivamente, afirma ser necessário não somente abranger como o presente e o futuro são equilibrados nas narrativas, mas também destacar, mais explicitamente, o passado das crianças e da infância. Parafraseando: além do being e do becoming, é preciso que haja uma terceira posição complementar, o been, abrigando, igualmente, o entendimento do passado nas vidas das crianças.

O autor acrescenta que esta noção triangular oferece um olhar mais produtivo para os estudos das crianças e da infância, porquanto envolve uma relação temporal mais complexa entre passado, presente e futuro. Outrossim, Hanson afirma que, em casos de pós-conflito, o passado não pode ser simplesmente esquecido, ainda mais quando crianças e jovens participaram do conflito armado. Por isso, as histórias das crianças e suas percepções sobre o conflito devem ser levadas em conta durante os processos de reconciliação social, com o objetivo de compreender as complexas relações sociais que causaram ao conflito. "Embracing the 'been' child might even lead to moving children from the periphery to the centre of the social world itself, that always incorporates dynamic but indeterminate relationships between past, present and future.” (Hanson, 2017, p. 284).

Já a proposta de Conrad (2011), em outro momento, traz a temporalidade dinâmica como forma de aprender mais sobre como as crianças podem se imaginar em relação ao tempo e imaginar também o tempo em relação a suas vidas. Ou seja, questionando a construção linear do tempo adulto, a temporalidade dinâmica 
representa uma produção criativa do registro temporal que envolve alongar o presente ou o passado através do aspecto gramatical e de escrita (por exemplo, flexão verbal ou uso de um tempo verbal específico como o presente ou passado contínuo), amarrar o passado no futuro por meio do presente, ligar o futuro no presente, entre outros aspectos de manipulação criativa.

A partir da leitura e análise de poemas escritos por jovens e crianças, Conrad demonstra como as crianças conseguem manipular o tempo por meio da linguagem lírica e trazer suas relações temporais e subjetivas com o mundo ao redor. Reconhecendo, igualmente, a multiplicidade e ambiguidade das visões sobre o tempo nos escritos das crianças, a autora não se limita em propor uma unitária 'perspectiva da criança', pois as plurais produções poéticas são capazes de abranger variadas formações criativas e subjetivas acerca dos arranjos temporais.

Dessa maneira, levando em conta a análise temporal crítica de Shapiro (2016) e Fasolt (2004), percebo que a proposta de Conrad (2011) sobre a temporalidade dinâmica consegue traduzir, de certa forma, as produções das temporalidades e subjetividades das crianças e, assim, também mostrar as complexas e plurais relações temporais entre as (ex-) crianças soldado e o (pós-) conflito. Ou melhor, o futuro anterior (will-have-been) na análise de Shapiro também representa uma proposta crítica de manipulação e modelagem do tempo por meio da gramática e da estrutura da escrita. Essas propostas, portanto, são capazes de mover além dos limites temporais estipulados e de remodelarem, criativamente, os contornos do tempo ao "stretching out duration, crossing temporal frames, subverting linear trajectories, or otherwise claiming power over time." (Conrad, 2011, p. 216).

The skills I learned for self-defence I can use when I go back to civilian life. [Excriança soldado das Filipinas, recrutado com doze anos]. (UNICEF, 2002, p. 57). ${ }^{23}$

Esses meios criativos e subjetivos de modelar o tempo, simultaneamente, trazem outras histórias e estórias do envolvimento militar sob a perspectiva das excrianças soldado - narrações plurais e múltiplas entre si - mesclando as temporalidades e dinamizando o modo como os eventos no grupo armado são colocados no passado. As possibilidades de narrar o passado militar e suas relações

${ }^{23}$ Com a finalidade de conceder destaque aos depoimentos das (ex-) crianças soldado, decidi apresentá-los sob o modelo de citação longa. 
na continuidade do ser no presente mostram como outras noções de superação e de futuro acabam sendo desenhadas.

Sendo assim, com a perspectiva da temporalidade dinâmica, Conrad propõe pensar no tempo da infância e da criança além do binarismo ser e tornar-se a fim de se abrir às multiplicidades e ambiguidades das produções temporais subjetivas. Por isso, voltando à foto da (ex-) menina soldado, vejo que a presença do espelho e da arma de fogo refletem as maneiras de se projetar o sujeito durante as temporalidades que se alongam nos discursos da (ex-) criança soldado. Trazer a (ex-) criança soldado como construtora de sua percepção temporal, igualmente, implica reconhecer as múltiplas temporalidades que compõem o sujeito narrador e que cercam as histórias e estórias do (pós-) conflito e do envolvimento militar infantil além daquelas de rupturas narradas pelo discurso adulto do retorno.

Ao questionar a noção opositora entre ser e tornar-se e ao abranger também o modo como as temporalidades são imaginadas pelas crianças, as histórias e estórias das ex-crianças soldado conseguem habitar um espaço discursivo e temporal de indecisão, incertezas e ambiguidades, traduzindo os desenhos temporais difusos de sua categoria, visto que, ao invés de se estabilizar em um modo específico de narração e também do sujeito narrador, a multiplicidade e dinamismo das temporalidades que se emaranham nos eventos trazem outras histórias e, em consequência, outras maneiras de contá-las. 


\section{3}

\section{A interrogação que se mantém: os desenhos temporais difusos das (ex-) crianças soldado}

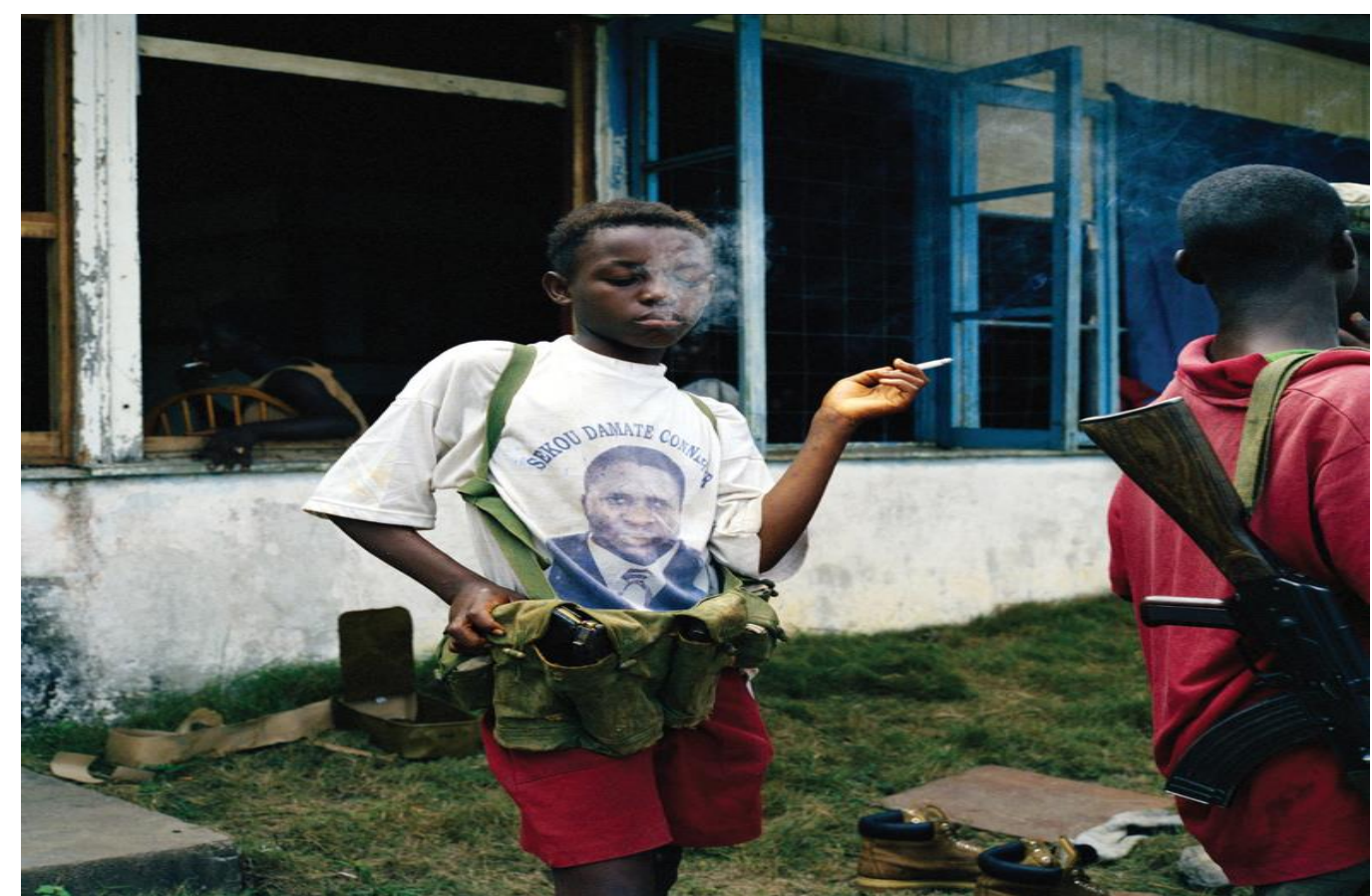

Figura 7: Foto do livro Child Soldiers de Leora Kahn (ed.), 2008. ${ }^{24}$

Durante as sombras dos retratos, esta imagem propõe um desafio: permanecer em interrogação. Por meio de incertezas, indistinções e inexatidão, as fronteiras entre a criança e o adulto e entre o feminino e o masculino se bagunçam e difundemse como a fumaça de um cigarro. Os contornos do silêncio mostram, através das palavras esfumaçadas que saem da boca da (ex-) criança soldado, um momento ambíguo para tornar-se presente. Os olhos fechados marcam as impossibilidades de se traduzirem esses incômodos que nos desviam olhares, é primeiro uma parcela de invisibilidade seguida por várias interrogações.

Noto, ainda, nesta foto, muitas outras maneiras de contar histórias que trazem o invisível e o não-dito sobre as temporalidades do envolvimento militar infantil e do (pós-) conflito. Os esquecimentos que envolvem tanto a (re)configuração do passado militar - narrado no tempo ausente e acabado do passado - quanto à mudança da percepção do "eu", antes soldado e agora civil (assim, criança) são refletidos, criticamente, quando a visão linear do tempo e a relação, essencialmente, de oposição entre os discursos do trauma e da resiliência são questionados.

24 Disponível também em: < http://www.powerhousebooks.com/books/child-soldiers/> Acesso em: 26 mar. 2018. 
Nessa perspectiva analítica, o sujeito ex-criança soldado resiliente, que reflete a imagem do herói redimido, descreve um passado militar como superado e, ao mesmo tempo, espera um futuro civil de estabilidade. As maneiras, primeiro, de narrar o passado traumático superado e depois da ex-criança soldado enxergar a si mesmo como criança e civil, são projetadas como modos racionais de superação, pois separaram, nitidamente, os dois mundos: o mundo do conflito armado moderno e o da infância moderna e, assim, conseguem ser traduzíveis no mundo adulto. Por conta disso, as outras histórias das ex-crianças soldado que trazem o passado militar no presente e a identidade do soldado são encaixadas nas linhas do 'estar traumatizadas' e movimentam reações de passividade e incômodo nas entrelinhas dos discursos tradicionais sobre a categoria (ex-) crianças soldado.

I don't regret being a combatant. I was able to serve the people, to help the needy. And that's one thing I can be proud of. [Ex-criança soldado das Filipinas, recrutado com quatorze anos]. (UNICEF, 2002, p. 56).

Essa fala, como exemplo, consegue abraçar outras formas de colocar as experiências militares nas (des)continuidade de um passado presente e perceber o "eu" nos "entres" do envolvimento no grupo armado. Portanto, outras percepções temporais e subjetivas de superação entram em cena, bagunçando as temporalidades entre o passado militar, o presente da criança e o futuro do adulto.

De outro lado, entretanto, uma história de superação é capaz de ser narrada quando a ex-criança soldado não mais reflete sua arma perante o espelho e o reflexo do soldado está no passado, nas conjugações verbais do pretérito. Logo, a possibilidade de projetar o passado militar como um tempo ausente e imutável é o que torna a ex-criança soldado um narrador resiliente, que conta racionalmente uma história de superação.

Esse modo de traçar o passado militar está em conexão com a própria linha construída entre passado e presente, ou seja, "absence and immutability are crucial for the fascination the past exercises over the minds of those who think of it. " (Fasolt, 2014, p.5). Assim, a produção do sujeito racional no centro do mundo moderno leva ao desenho de um determinado entendimento temporal e de um certo posicionamento do ser humano perante o tempo. Dentre uma concepção temporal linear adulta e dividida entre antes/agora/depois, as histórias das crianças, neste 
caso das (ex-) crianças soldado, são posicionadas em um discurso temporal de desenvolvimento (tornar-se) e de superação (resiliência).

É neste sentido que vejo o prefixo temporal 'ex', nos discursos plurais da resiliência para a categoria ex-criança soldado, movimentando a capacidade de (re)configurar o passado militar e também de esperar um futuro estável por meio de esquecimentos subjetivos e temporais. Esquecimentos esses que demandam um olhar antagônico entre o 'estar traumatizada' e o 'ser resiliente' e também entre a criança e o soldado, construindo um ideal específico de superação para ex-criança soldado. Todavia, as ambíguas temporalidades que se cruzam nas plurais histórias e estórias das ex-crianças soldado mostram o quão (des)contínuas e complexas são as relações entre os discursos do trauma e da resiliência as quais (re)produzem sua categoria.

Thinking back, it was a good experience for me. If I had stayed in the town, without enough food I might have had to do something bad, such as stealing or something like that. Now I think more about studying, continuing my education. Now my aim is not to be a soldier but to do other things. I would like to go to Bible school. [Excriança soldado de Myanmar, recrutada com doze anos] (UNICEF, 2002, p. 56).

I've changed my way of thinking now and want to complete my education. Fighting would be my second priority. [Ex-criança soldado de Papua Nova Guiné, recrutada com oito anos]. (UNICEF, 2002, p. 67).

I am a registered soldier - even if under false identity of an adult soldier who already died - and in theory I am eligible for the benefits promised under the demobilization programme. [Ex-criança soldado de Camboja, recrutado com treze anos Camboja]. (UNICEF, 2002, p. 69).

Desse modo, as temporalidades e a maneira como as crianças se percebem em relação ao tempo, de acordo com essas falas, mobilizam diferentes e difusas percepções temporais e subjetivas sobre o envolvimento militar e o (pós-) conflito. No terceiro depoimento, por exemplo, a ex-criança soldado identifica-se no presente como um soldado formalizado, enquanto se localiza nos processos de desmobilização (como combatente).

As histórias e estórias das (ex-) crianças soldado, portanto, marcam vários modos de perceber os plurais envolvimentos militares das crianças em cada contexto social, abrangendo os contornos temporais e sociais de cada (pós-) conflitos. As (des)continuidades temporais entre a (ex-) criança soldado e o (pós-) conflito refletem quão ambíguas e complexas são as relações entre o 'estar 
traumatizada' e o 'ser resiliente' que qualificam a sua categoria, indo além dos antagonismos que marcam sua posição de espera no presente.

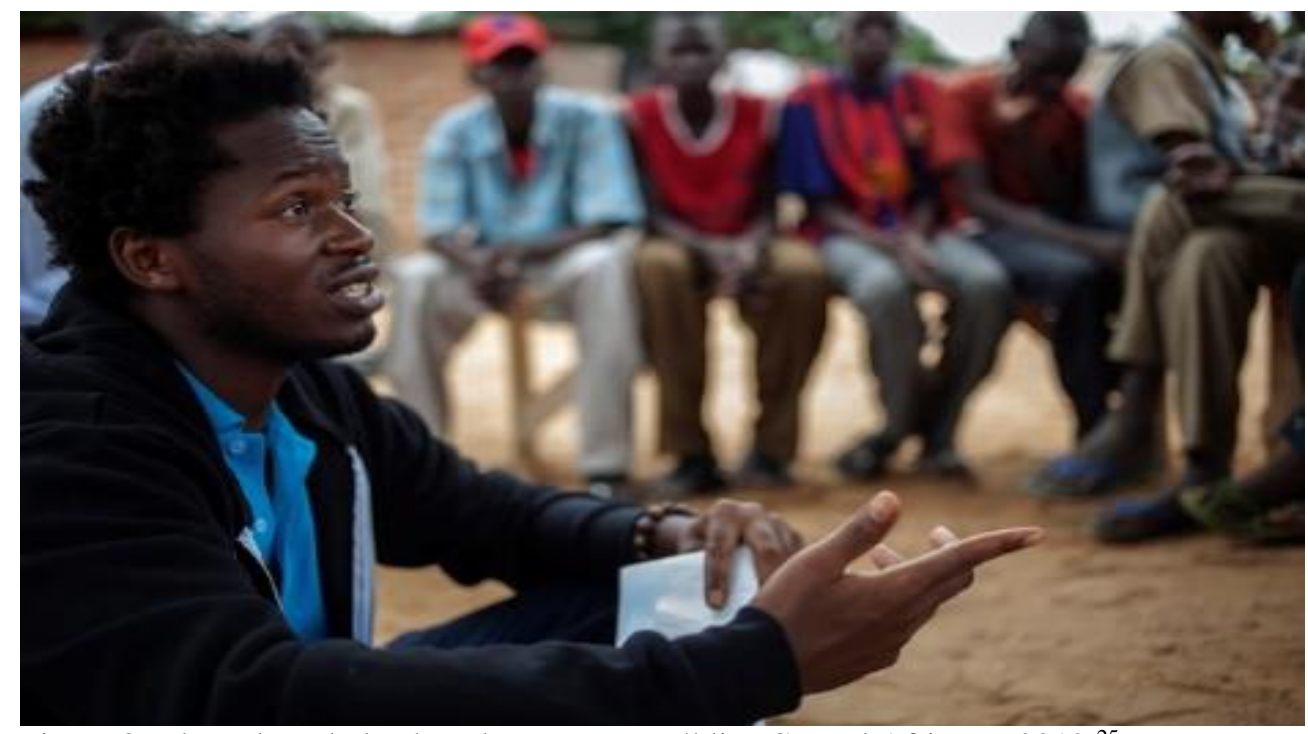

Figura 8: Ishmael Beah dando palestras na República Central Africana, 2012.25

As desenvolturas do falar/narrar/contar uma história de superação para as excrianças soldado e os processos de tradução envolvidos nesses discursos são capazes de refletir um ideal de unificação e homogeneidade, tanto em relação à categoria ex-criança soldado, quanto à projeção de um caminho de superação. A foto de Ishmael Beah transparece, por entre fala e escuta, uma certa relação de permissões e negações, desvios e possibilidades no vai e vem das palavras, uma vez que, para moldar uma "história de sucesso", determinados esquecimentos e promessas estão em jogo entre o 'estar traumatizada' e o 'ser resiliente'.

Destarte, a concepção de redenção, ou melhor, a imagem do herói redimido trazido por Denov (2010) marca esta posição temporal específica do sujeito narrador e sua mirada ao passado militar, posto que o prefixo temporal 'ex' traz também a possibilidade de projetar uma redenção por meio do distanciamento da (ex-) criança soldado tanto do grupo armado quanto do conflito, reafirmando o ideal de retorno à infância moderna como caminho de superação. Assim sendo, a excriança soldado redimida é quem sobreviveu aos males da guerra e agora se mostra capaz de lidar com o passado militar traumático e retomar o curso natural do

\footnotetext{
${ }^{25}$ Inter Press Service (ago. 2012). Disponível em: <http://www.ipsnews.net/2012/08/qa-swappingchildren-for-protection-in-central-african-republic/ishmael-beah-unicef-advocate-for-childrenaffected-by-war-visits-central-african-republic/> Acesso em: 28.jan 2017.
} 
desenvolvimento infantil. Histórias e trajetórias como aquelas contadas nas músicas de Emmanuel Jal e no livro de Ishmael Beah (por mais ambíguas que se apresentem) ganham um status de celebridade e fama, principalmente nas sociedades ocidentais, silenciando outras estórias de outras (ex-) crianças soldado, cujas traduções não se acomodam no discurso adulto do retorno (ocidentalizado).

Além disso, segundo Mastey (2016), o livro de Beah foi a história sobre criança soldado mais bem-sucedida cultural e financeiramente entre o público leitor ocidental. Este fato se deu por conta do crescente interesse, por parte dos leitores dos Estados Unidos (por exemplo), desse gênero literário específico, que narra as dificuldades e mazelas das relações entre as (ex-) crianças soldado e o (pós-) conflito armado, em sua maioria, localizadas no continente africano.

Essas histórias sobre crianças soldado como gênero foram, recentemente, inseridas como produto cultural de um tempo em que o recrutamento militar infantil está em voga nos discursos públicos, políticos, sociais e de segurança. Englobado no campo da literatura de miséria (não-ficcional), o gênero das crianças soldado traz histórias de personagens que passaram por inúmeros abusos físicos e emocionais, mas conseguiram superar essas circunstâncias trágicas e se deram 'bem na vida'.

No que tange à (re)produção dessas histórias em livros, o sucesso de publicação e de venda está relacionado à modelagem e mistura de cenas (construídas como não-ficcionais) de violência e de redenção do ser criança (no singular) que levam o leitor a computar certos significados e sentidos das informações presentes nas narrativas. Ou seja, o leitor se vê lidando com a relação paradoxal e conflituosa entre dois mundos: o da infância moderna e o do conflito armado moderno.

Some of these characteristics are self-evident: the protagonists are African children recruited by government or non-state forces to be soldiers. But there are other essential traits that also bind the works together. They offer scenes of life prior to enlistment and following decommission, but a majority of the narratives emphasize their wartime experiences. All but one of the characters are combatants in the traditional sense - they are responsible for maiming or murdering other young people and adults, the destruction and theft of property, and, in roughly half of the works, sexual violence. Sometimes this behaviour is coerced by comrades or commanding officers, but these characters are also frequently depicted as willing participants in criminal activities. The narratives reflect on sociopolitical circumstances that would lead to child soldiering, its embrace by some adults and rejection by others. They portray the traumatic effects of the practice on the children themselves, as well as on 
western conceptions of childhood that US readers are assumed to possess. Finally, they nearly always gesture towards the possibility of redemption. A few characters are ultimately denied in this regard, but many others are given the opportunity to become children again, often through the intercession of western humanitarian aid workers and in several cases by ultimately settling in western countries. (Mastey, 2016, p. 148).

Essa concepção de redenção, de certa forma, distorce a noção linear de tempo, pois se configura como um retorno a um estado inicial marcado, neste caso, por uma volta ao ideal da infância moderna, para que seja possível, por conseguinte, retomar ao tal curso linear e progressivo do tempo de desenvolvimento rumo ao sujeito adulto. Outrossim, acredito que, ao problematizar as desenvolturas temporais demarcadas, as marcas do sujeito redimido (a principal face do ser resiliente para a ex-criança soldado) bagunçam e ajeitam o fluxo linear contínuo do tempo em busca de uma união, harmonia e estabilidade tidas como 'perdidas'.

Contudo, as demais cenas de redenção que se mantêm nos desenhos temporais do envolvimento militar infantil e do (pós-) conflito traduzem eventos difusos que se emaranham nas construções das variadas histórias e estórias da ex-criança soldado e também durante a incerteza da presença ou não do prefixo 'ex' em sua categoria - mostrada aqui pelo uso do parêntese.

Ademais, inspirada pela análise estética da política de Shapiro $(2013,2016)$ e Rancière (2009), mostro como os desenhos temporais difusos e ambíguos da categoria (ex-) criança soldado são capazes de romper com certas distribuições das falas e dos silêncios, do visível e do invisível e das maneiras de traduzir específicas posições temporais e identidades. Nesse mesmo enfoque, Bleiker assevera que

aesthetic approaches, by contrast, embark on a direct political encounter, for they engage the gap that inevitably opens up between a form of representation and the object it seeks to represent. Rather than constituting this gap as a threat to knowledge and political stability, aesthetic approaches accept its inevitability. (p. 512).

Desse modo, tais análises estéticas mostram as incompletudes e as incertezas que rodeiam os processos de significações, abrindo-se às outras formas de representação dos sujeitos, objetos e relações. Portanto, refletir a partir de (des)encontros com as plurais representações artísticas nos traz um modelo diferente de dúvida e de questionamento, cujas críticas incomodam as maneiras comuns de pensar e de tornar inteligível a realidade social. 
Aqui mais uma cena. Agu chega à tenda de seu comandante e o avisa sobre a falta de munição dentro do grupo, alguns dos outros garotos se aproximam deles e anunciam que irão sair do grupo armado por causa da ausência de planos, comida, dinheiro, água e munição. A partir dessa atitude, o comandante se levanta, lentamente, e discursa para os meninos soldado sobre as trágicas consequências desse ato de saída, enfatizando a rejeição das famílias e das comunidades, o desemprego generalizado e o desamparo social e nacional. Seu movimento de falar e caminhar por entre os garotos busca traçar um momento para o envolvimento militar, dizendo: “- Eu sou o futuro de vocês”, e um dos meninos lhe aponta a arma.

“- Como vai atirar em mim se não tem munição?" O comandante pergunta ao garoto enquanto saca sua própria arma. Ao final da pergunta, Agu lhe aponta sua arma. O comandante ajoelha em sua frente: “- E você, Agu? Quer matar seu comandante? [...]. Quer se render? ” Agu responde em afirmativo à última pergunta, e o homem se levanta, novamente, ordenando que os garotos partam. Todos vão caminhando para a partida, no entanto Agu permanece ao lado do comandante até o momento em que o homem se vira e começa a caminhar de volta a sua tenda, gritando.

De costas ainda, o comandante diz: “- Agu, fique aqui, porque eles não...” e quando se vira, percebe-se falando sozinho. Agu seguia seus companheiros rumo à retirada.

Essa cena, para minha análise, compartilha muitas temporalidades sobre a concepção temporal de redenção e da categoria (ex-) criança soldado entre o sair, permanecer, morrer, viver e voltar. Render-se, neste espaço temporal, envolve, para Agu, (sobre)viver nas incertezas, sair delas e voltar a elas, além das ambiguidades de sua posição espacial e temporal como (ex-) criança soldado. Durante os movimentos corporais dos meninos soldado e do seu comandante, Agu se rende perante seu envolvimento militar já não mais desejoso de permanecer no presente e nem de se alongar em um futuro; deixando, entretanto, rastros que marcam as plurais subjetividades e temporalidades de sua categoria.

Por isso, considero que ir além do binarismo ser e tornar-se e da visão antagônica entre os discursos plurais do trauma e da resiliência possibilita-nos reconhecer as pluralidades e ambiguidades que cercam a (re)produção da categoria ex-criança soldado. E, ao mesmo tempo, como as entrelinhas do contar uma história de superação busca estabelecer uma subjetividade infantil e a temporalidade da 
criança que espera. A interrogação estaria relacionada, nesses discursos, à posição da ex-criança soldado no presente que espera para tornar-se um adulto e ser resiliente; o futuro, neste caso, traria uma certeza impossível de permanecer no presente. Porém, quando as temporalidades são bagunçadas, discussão que tentei elaborar com minha análise crítica do tempo, a posição de interrogação da categoria ex-criança soldado se mantém a partir de complexos relacionamentos e ambíguas vivências do (pós-) conflito e do grupo armado.

Passado, presente e futuro se alongam, misturam-se e ganham outras relevâncias e sentidos políticos e subjetivos, sejam no âmbito individual e/ou coletivo, no passo das histórias e estórias das (ex-) crianças soldado. Consequentemente, as relações ambíguas entre os discursos do trauma e os da resiliência para a ex-criança soldado que amarram os eventos e suas temporalidades em definições difíceis de permanecerem conseguem dinamizar as temporalidades sob a ótica das crianças e suas narrativas.

\section{4 \\ Concluindo: bagunçando as temporalidades}

A posição incômoda da categoria ex-criança soldado no presente, dentre os discursos do trauma e da resiliência que formam sua categoria, movimenta os discursos da criança (no singular) que espera, junto com o desejo de superação do passado militar traumático. Nesse caso, o prefixo 'ex' traz um passado militar que necessita ser (re)configurado a fim de ser contado pela ex-criança soldado resiliente que espera um futuro adulto estável. Assim, conversando com os dois sentidos do termo espera na língua portuguesa - aguardo e esperança - minha análise trouxe o modo como a categoria ex-criança soldado espera um momento para ser adulto e, ao mesmo tempo, resiliente. Essa posição de espera delimita o pensar sobre a categoria (ex-) criança soldado entre o 'estar traumatizada' e o 'ser resiliente' por meio da construção de um passado militar traumático, um presente de espera e a esperança de um futuro estável no mundo adulto.

A partir do exposto, constata-se que há a projeção de um ideal específico de superação para ex-criança soldado capaz de colocar o envolvimento militar no passado (tempo acabado e imutável) e de trazer identificação do ser criança (no singular) como o desejado reflexo do espelho. Contudo, quando as múltiplas 
temporalidades que (de)formam as histórias e estórias das (ex-) crianças soldado são bagunçadas, esta posição de interrogação de sua categoria se mantém por entre os complexos relacionamentos e ambíguas vivências do (pós-) conflito e dentro do grupo armado.

Ademais, os discursos sobre ser (human being) e tornar-se (human becoming) e, principalmente, as análises que questionam o antagonismo de suas relações trouxeram a possibilidade de mostrar os desenhos temporais difusos da categoria (ex-) criança soldado nos "entres" do tempo. Então, seja através do questionamento do discurso temporal linear seja pela crítica da visão, essencialmente, contrária entre os discursos do trauma e da resiliência que formam a categoria (ex-) criança soldado, as linhas e vozes presentes nas variadas outras histórias de superações ganham pluralidade e ambiguidades.

A interrogação que permanece vai e volta no prefixo temporal 'ex' e mostra sua presença durante os desvios e possibilidades concedidos às (ex-) crianças soldado ao narrar suas histórias e estórias. Isto é, as perguntas e dúvidas que guiam as (des)continuidades temporais entre as (ex-) crianças soldado, o envolvimento militar e o (pós-) conflito continuam, deixando suas marcas, representadas pela presença do parêntese, que aqui, traduz os difusos desenhos temporais e subjetivos da sua categoria. Construo, dessa forma, o parêntese como um recurso gráfico com presença política, capaz de desenhar e bagunçar as temporalidades que produzem a ex-criança soldado ora como traumatizada ora como resiliente em posição de espera no presente. Os desenhos temporais difusos da categoria (ex-) criança soldado encontram, portanto, no parêntese um modo de permanecer ambiguidade e interrogação durante as múltiplas temporalidades que abraçam a criança soldado, a ex-criança soldado, o adulto, a infância e a adultez. 


\section{5 \\ Considerações Finais: os "entres" temporais e as estórias das ex-crianças soldado}

Ao escutar, de novo, a batida pesada de Emmanuel Jal "I believe I've survived for a reason to tell my story to touch lives (touch lives, touch lives touch lives, touch lives) " (Jal, 2008), penso que poderia ter começado esta história acadêmica, desde o início, com o conhecido era uma vez, pois, acredito que seja a maneira como muitas passagens da vida desejariam ser narradas. Entretanto, nestas linhas, fui da vírgula ao ponto, incomodando o era do pretérito imperfeito - de um passado longínquo - e o uma vez da unidimensional essência e representação do evento.

Vários dos meus livros infantis contavam suas histórias a partir do era uma $v e z$, partiam desta expressão a fim de trazerem, em seu nome, específicas expectativas e, por isso, resgatavam a linearidade fixada do tempo entre passado (era), presente (ato de narrar) e futuro (o confortável final feliz). Por mais que a narrativa chegasse a um clímax desafiador a(o) personagem principal, a certeza do “feliz(es) para sempre” permanecia, ou melhor, de que o evento 'traumático' estava mergulhado e afundado nas memórias que me eram apresentadas, naquele momento, pelo narrador (adulto), porém não mais afetavam a vida presente dos personagens. Essas histórias dos meus livros já havia sido uma vez e agora era narrada com o intuito de se fazer conhecer.

Era no cômodo final feliz das histórias infantis que os personagens permaneciam desenhados no final das histórias, todos sorrindo para a eternidade. Por entre as narrativas de superação, os participantes ganhavam existências ao contar suas histórias, como modelos e exemplos de lutas e glórias, seus depoimentos, portanto, iam sendo reproduzidos com o objetivo de esboçarem uma "lição de vida" específica e uma "história de sucesso". A fala e a escuta dos personagens eram, igualmente, guiadas por um mecanismo de compreensão do que venha a ser um evento traumático, a partir de rupturas, e conceber a superação como resolução. Ou melhor, uma determinada superação - nas entrelinhas do ser resiliente - como capaz de trazer um futuro feliz.

Outrossim, reconheço que essas histórias movem mais do que ideais de superação, traduzem também um entendimento temporal determinado para o sujeito narrador, junto a um desejo de unidade e coerência que nos possibilita traçar 
divisões entre o passado, presente e futuro. Como agora adulta, reconheço o compasso que essas narrativas mobilizam e as expectativas que são projetadas para a adultez, sendo o adulto construído como sujeito autônomo, competente e estável capaz de movimentar relações de autoridade baseadas em convenções fictícias sobre essa etapa. A necessidade de afirmação do sujeito adulto como autônomo e independente, em oposição à criança, firma-se em processos difíceis de se manterem nas experiências e vivências entre a infância e adultez.

Essa concepção do adulto foi criada e mantida com a finalidade de assegurar certas relações de poder e autoridade deles perante às crianças. Porém, assim como Lee (2011) afirma, “[...] this assumption of finished stability no longer holds good in either adult's working lives or in their intimate relationships." (p.19). Neste sentido, as múltiplas relações e temporalidades que marcam as experiências das 'misturas' entre o ser e tornar-se traduzem também incertezas e instabilidades no mundo adulto e 'bagunçam' as linhas temporais, espaciais e culturais que separam a infância e a adultez, a criança e o adulto.

Deixo aqui uma reflexão, capturada de uma das inúmeras cenas marcantes do filme, que consiste na cena de uma partida, quando Agu, em sua meninice, é obrigado pelo seu pai a deixar a cidade junto com sua mãe, sua irmã mais nova e o bebê, uma vez que fora decidido que crianças e mulheres deveriam abandonar a vila antes dos ataques, enquanto os homens ficariam para protegê-la. No momento da partida, várias cores se mesclam com o movimento das pessoas que buscam, freneticamente, uma vaga entre os carros que partem, as cenas rápidas e as passagens dão a ideia de fluxo intenso de pessoas, animais e coisas se misturando em multidões. Contudo, há uma passagem de câmera que mostra, ao fundo, soldados fardados segurando armas na varanda somente observando a movimentação abaixo, havendo, neste ponto, um contraste entre a estabilidade militar e a instabilidade civil.

A travessia de Agu até a capital - sua saída da vila - era exata e tudo estava até então planejado, no entanto, seu pai não obteve sucesso ao barganhar outra vaga além da de sua mãe, da menina e do bebê dentro do carro, visto que o motorista, rodeado por inúmeras propostas e notas, não estava aberto para diálogo e negociação. As ações e decisões deveriam ser rápidas: ou todos ficavam ou somente a mãe e as crianças mais novas iriam. A separação entre mãe e filho é marcada por choro, emoção, promessas e indecisões. 
O movimento de Agu é confuso, não lhe era permitido ficar até então, sua construída vulnerabilidade infantil o jogava para fora da cidade, todavia, naquele momento, ele era compelido a permanecer junto aos homens adultos. Nesta posição, neste vão temporal, existe um desvio espacial, seu lugar agora é aquele não esperado ou planejado: o do mundo adulto masculino da esperada coragem e maturidade.

A imagem e a cena transmitem relações de incertezas e dúvidas, o ambiente movimentado e a figura de Agu correndo sem consolo, distanciando-se de seu pai, parece nos incomodar de inúmeras formas. Seu corpo permanece em interrogação por entre os processos de ser e tornar-se criança/adulto. Essa infância dada ao menino e, ao mesmo tempo, suspendida, mobiliza concepções de dúvidas entre a inocência e imaturidade, que demarcam o espaço e o tempo esperado para a criança e a maturidade do sujeito adulto, o qual permanece na violência do conflito.

Em face disso, durante esta dissertação, busquei mostrar como a categoria (ex-) criança soldado foi adquirindo sentido, entendimento, permissões e negações dentro de, principalmente, específicos discursos do trauma e da resiliência que a (re)produzem, a partir de uma noção temporal adulta de rupturas e (des)continuidades.

As construções discursivas dominantes (da chamada 'frouxa coalizão') para as (ex-) crianças soldado as formam como 'novo problema' no cenário internacional, em urgência de controle e erradicação, no durante e após seu envolvimento militar. Esses discursos são capazes de construir um imaginário da ex-criança soldado e de sua alocação temporal entre a (re)produção das narrativas da infância moderna, do conflito armado moderno e do tempo moderno, por meio dos desvios e possibilidades projetados para sua categoria no presente.

Nesse enfoque, relacionei a projeção da (ex-) criança soldado como desviante em relação a dois pontos, em específicos: primeiro, o da infância moderna ideal da criança, essencialmente inocente e, segundo, o da sua posição incerta e duvidosa no presente, capaz de ser traduzida por meio do passado militar e do futuro adulto. A posição da ex-criança soldado no presente é incerta e incômoda, por isso a principal pergunta que guia sua ocupação temporal se vê traduzida nos contornos difusos entre passado e futuro. Isto é, será a ex-criança soldado capaz de superar seu passado traumático e se transformar em um sujeito adulto 'saudável' e 'bemsucedido'? Entre o passado miliar e o futuro adulto, o presente é a espera (aguardo 
e, ao mesmo tempo, esperança), um tempo mencionado entre esquecimentos e superação para a categoria (ex-) criança soldado.

Em contrapartida, as possibilidades que lhe cabem vêm através de uma ideia de retorno à infância desejada, cujas falas ganham sentido na vitória da ex-criança soldado resiliente perante seu passado militar traumático. Por esse motivo, minha intenção foi refletir e questionar a posição fixada do prefixo 'ex' no passo do seu entendimento temporal e o quanto noções de rupturas entre a normalidade e o desvio entre passado e presente vão se apoiando em uma visão unificante da relação entre infância moderna e conflito armado moderno.

Contudo, a coexistência das múltiplas temporalidades durante as histórias e estórias das (ex-) crianças soldado mostram as (des)continuidades temporais que guiam o modo de se pensar a infância moderna (ocidentalizada) em relação ao (pós-) conflito moderno (não-ocidental). Já que, entre chegadas e partidas, inexiste coesão, exatidão e simplificação. As histórias e estórias das (ex-) crianças soldado se desenrolam de modo (des)contínuo e bagunçado, embaralhando as imagens que as qualificam entre traumatizadas e resilientes e entre passado militar negativo e futuro do adulto estável.

Sob esse prisma, a fim de mostrar os discursos da resiliência (em relação aos do trauma) que formam a categoria ex-criança soldado, analisei três documentos de linguagens e escritas diferentes, plurais entre si, que modelaram entendimentos temporais e subjetivos específicos para a categoria (ex-) criança soldado entre o 'estar traumatizada' e o 'ser resiliente'. O primeiro documento foi o Handbook of Resilience in Children of War (2013), organizado por Chandi Fernando e Michel Ferrari; depois, o manual para fins humanitários Iasc Guidelines on Mental Health and Psychosocial Support in Emergency Settings (2007), e o terceiro foi a narrativa autobiográfica de Ishmael Beah "Muito longe de casa: memórias de um meninosoldado".

Esses textos traduzem, cada um a seu modo, os intentos de afirmar ou silenciar um significado estável para a categoria ex-criança soldado e sua alocação temporal. As discussões sobre os textos, entretanto, trouxeram fissuras de incertezas e mais questionamentos sobre a posição temporal incômoda da (ex-) criança soldado e o ato de narrar uma história de superação, construídos a partir da relação antagônica entre o 'estar traumatizada' e o 'ser resiliente'. As diversas experiências e vivências das (ex-) crianças soldado mostram quão (des)contínuas se apresentam 
suas posições temporais e as configurações do seu passado militar, tendo em vista que as relações difusas e ambíguas entre os discursos do trauma e da resiliência se dão além de apenas oposições, estando também em deslocamentos, sobreposição, ambiguidades, complementaridades e simultaneidade. Portanto, a interrogação que se mantém, durante a posição incômoda da ex-criança soldado no presente, reflete histórias e estórias de multiplicidade, heterogeneidade e ambiguidades, mesmo que haja tentativas de afirmar e manter a estabilidade de uma certa relação entre as (ex-) crianças soldado e o (pós-) conflito.

Sendo assim, as análises temporais críticas de Shapiro (2016), Fasolt (2004) e Conrad (2011), principalmente, ajudaram-me a montar as reflexões sobre os difusos desenhos temporais da categoria (ex-) criança soldado a partir de propostas políticas de escrita. São linguagens que questionam a produção das linhas divisórias, trazendo alternativas de análises através dos encontros com o estético e englobando a produção criativa do tempo. As formas criativas e subjetivas de se projetar o tempo marcam outras histórias e estórias do envolvimento militar sob a perspectiva das ex-crianças soldado, narrações plurais e múltiplas que misturam as temporalidades e dinamizam o modo como as vivências no grupo armado são conjugadas no passado.

Dessa forma, percebo que, ao questionar a visão opositora entre ser e tornarse e também entre o 'estar traumatizada' e 'ser resiliente' que formam a categoria ex-criança soldado, recontamos mais outras histórias sobre outras maneiras de trazer os tempos e as temporalidades em cena, tanto dos (pós-) conflitos no plural, quanto dos variados tipos de envolvimento militar infantil. Esclareço que, de modo algum, estou projetando uma postura positiva sobre os conflitos armados e o envolvimento militar infantil, mas sim, problematizando as relações discursivas homogêneas e fechadas que guiam seus entendimentos, relações essas incapazes de abranger as ambiguidades e multiplicidades na produção dos eventos.

Os conceitos e categorias, antes naturalizados, são colocados em espaços e tempos de incertezas, ambiguidades, coexistências e dinamismos, posto que, ao invés de se estabilizarem em um modo específico de narração, as múltiplas temporalidades que se emaranham trazem outras histórias e estórias e diferentes maneiras de contá-las.

Além disso e em virtude das relações mencionadas, nesses meus (des)começos, envolvi-me na análise estética da política a partir de (des)encontros 
que me fizeram refletir e questionar, principalmente, a estabelecida alocação temporal da ex-criança soldado e suas histórias.

Apoiando em teorias de Rancière (2009), o qual traduz a estética da política como "um recorte dos tempos e dos espaços, do visível e do invisível, da palavra e do ruído que define ao mesmo tempo o lugar e o que está em jogo na política como forma de experiência. " (p. 17), expus as fissuras e ambiguidades das disposições sensíveis, das maneiras de se contar uma história de superação dentre certos tempos. Outrossim, busquei questionar as posições da ex-criança soldado ora como traumatizadas, ora como resiliente ao mostrar quão difusos são seus desenhos temporais.

Mostrar esses desenhos temporais difusos das ex-crianças soldado foi essencial para se abrirem espaços e tempos outros capazes de abraçar variadas análises sobre infância, temporalidades, eventos, trauma e resiliência e se reconhecerem as (des)continuidades e ambiguidades que as cercam. Pretendo, em passos futuros, seguir explorando as relações ambíguas e plurais da (re)produção da categoria (ex-) criança soldado com o (pós-) conflito por meio de reflexões estéticas e de linguagem.

Ademais, considero que trazer mais elementos empíricos e expandir o vínculo entre as ex-crianças soldado e os modos artísticos apresenta-se como formas de englobar as outras estórias silenciadas e as imagens não-visíveis que se projetam no imaginário ideal construído para sua categoria. Dando um fluxo contínuo a esse raciocínio, penso, futuramente, trazer novas reflexões sobre, por exemplo, as perspectivas de gênero que traduzem as experiências e vivências das ex-meninas soldado e seus diferentes olhares sobre as temporalidades do envolvimento militar infantil.

Enfim, esta dissertação fez me (des)conhecer um pouco mais, olhar por entre os espelhos de minhas palavras e reconhecer os desvios e possibilidades que cercam os meus encontros com as imagens, falas e filmes das (ex-) crianças soldado. Vi meu ser e meu tornar-se em interação durante os tempos e temporalidades da minha escrita, bagunçando os processos que me tornaram e os que me fazem ser pesquisadora, internacionalista, brasileira, adulta e mulher. Portanto, vou permitir ao meu desfecho ser interrogação e não afirmação: sob quais interrogações nossas histórias e estórias permanecem? 
6

\section{Referências bibliográficas}

BAKAKI, Z.; HINKKAINEN, K. Do child soldiers influence UN Peacekeeping? International Peacekeeping, v.23, p. 540-567, 2016.

BALL, N.; VAN DE GOOR, L. Disarmament, Demobilization and Reintegration: Mapping issues, dilemmas and guiding principles. Clingendael Research Paper. Haia: Netherlands Institute of International Relations, 2006.

BARBER, B. K.; DOTY, S. B. How can a majority be resilient? Critiquing the utility of the construct of resilience through a focus on youth in contexts of political conflicts. In: FERNANDO, C.; FERRARI, M. (Eds.). Handbook of resilience in children of war. New York: Springer, 2013. p.233-52.

BAUMAN, Z. Modernidade líquida. Tradução Plínio Dentzien. Rio de Janeiro: Zahar, 2001.

$\mathrm{BEAH}$, I. Muito longe de casa: memórias de um menino-soldado. 1.ed. Tradução Cecilia Giannetti. São Paulo: Companhia de bolso, 2015.

BEN-ARI, E. Facing child soldiers, moral issues, and 'real soldiering': anthropological perspective on professional forces. Militaria: African Journal Military Studies, v.37, n.1, p.1-24, 2009.

BETANCOURT, T. S.; KHAN, K. T. The mental health of children affected by armed conflict: protective processes and pathways to resilience. International Review of Psychiatry, v. 20, n.3, p. 1-17, 2008.

BHABHA, J. The child: what sort of human? PMLA, v.121, n.5, p.15261535, 2006.

Child migration \& human rights in a global age. New Jersey: Princeton University Press, 2014.

BLEIKER, R. The aesthetic turn in International Political theory. Millennium: Journal of International Studies, v. 30, n. 3, p. 509-533, 2001.

BOYDEN, J. Children's experience of conflict related emergencies: some implications for relief policy and practice. Disaster, v. 18, n.3, p. 254-67, 1994.

The moral development of child soldiers: what do adults have to fear? Peace and Conflict: Journal of Peace Psychology, v.9, n.4, p.343362, 2003.

BRETT, R.; SPETCH, I. Young Soldiers: Why they Choose to Fight. Boulder, CO: Lynne Rienner, 2004. 
BOUREBEAU, P. Resilience and International Politics: premises, debates, agenda. International Studies Review, v.17, p. 374-395, 2015.

BROCKLEHURTS, H. Children and War. In: COLLINS, A. (Ed.). Contemporary Security Studies: Oxford University Press, 2006.

BUCHANAN, M.J. et al. Children of war in Colombia and Iraq. In: FERNANDO, C.; FERRARI, M. (Eds.). Handbook of resilience in children of war. New York: Springer, 2013. p. 107-16.

BURMAN, E. Innocents abroad: western fantasies of childhood and the iconography of emergencies. Disasters, v.18, n.3, p.238-253, 1994.

Routledge, 2008.

Deconstructing developmental psychology. 2.ed. London:

CARUTH, C. Unclaimed experience: trauma, narrative, and history. London: The Johns Hopkins University Press, 1996.

CARAMÉS, A.; FISAS, V.; SANZ, E. Analysis of Disarmament, Demobilization and Reintegration programs existing in the world during 2006. Escola de Cultura de Pau, 2007.

CHANDLER, D. Resilience and the autotelic subject: toward a critique of the societalization of security. International Political Sociology, v.7, n.2, p.210-226, 2013.

Resilience and human security: the post-interventionist paradigm.

Security dialogue, v.43, n.3, p. 213-229, 2012.

. Resilience ethics: responsibility and the globally embedded subject. Ethics \& Global Politics, v.6, n.3, p. 175-194, 2013.

CLAUSEWITZ, C.V. Da Guerra. 1.ed. Tradução Maria Teresa Ramos. São Paulo: Martins Fontes, 1979.

COALITION TO STOP THE USE OF CHILD SOLDIERS. Child Soldiers Global Report 2008. London, 2008a.

Londres, 2008b.

Returning Home: Children's perspectives on reintegration.

COALICIÓN ESPAÑOLA PARA ACABAR CON LA UTILIZACIÓN DE NIÑOS SOLDADO. Informe Global: Niños Soldados. Edición resumida, 2004. Disponível em:

$<$ http://www.entreculturas.org/files/documentos/biblioteca/Menores_Solda do_Informe_Global_2004.pdf?download>. Acesso em: 20 fev. 2018.

COOK, D.T. Editorial: When a child is not a child, and other conceptual hazards of childhood studies. Childhood, v.16, n.1, p. 5-10, 2009. 
CONRAD, R. 'My future doesn't know ME': Time and subjectivity in poetry by young people. Childhood, v. 19, n. 2, p. 2014-2018, 2011.

COUTO, M. Na berma de nenhuma estrada: e outros contos. São Paulo: Companhia das letras, 2015.

2009.

. E se Obama fosse africano? São Paulo: Companhia das letras,

CORTES, L.; BUCHANAN, M. J. The experience of Columbian child soldiers from a resilience perspective. International Journal for the Advancement Counselling, v. 29, n. 1, p. 43-55, 2007.

D'COSTA, B. Children and justice: past crimes, healing and the future. In: D'COSTA, B.; HUYNH, K.; LEE-KOO, K. (Eds.) Children and Global Conflict. Cambridge: Cambridge University Press, 2015.p. 212-248.

DAUPHINEE, E. The ethic of Autoethnography. Review of International Studies, v.36, n.3, p. 799-818, 2010.

DENOV, M. Child Soldiers: Sierra Leone's Revolutionary United Front. New York: Cambridge University Press, 2010.

DERLUYN, I. et al. Victims and/or perpetrators? Towards an interdisciplinary dialogue on child soldiers. BMC International Health and Human Rights, v. 15, n. 28, p.15-28, 2015.

DERRIDA, J. Monolingualism of the other: or the prosthesis of origin. Translated by Patrick Mensah. Stanford: Stanford University Press, 1998.

DRUMBL, M. Unlawful recruitment and use of children: from proscription to prevention. In:__ Reimagining Child Soldiers in International Law and Policy. New York: Oxford University Press, 2012. p. 134-137.

EMMANUEL. Warchild. E. Jall. [Compositor]. In: Warchild. [S.I.]: Sonic360, 2008. 1 CD (ca. $47 \mathrm{~min} 41 \mathrm{~s})$. Faixa 1 (3 min $51 \mathrm{~s}$ ). Remasterizado em digital.

ESTATUTO DE ROMA DO TRIBUNAL PENAL INTERNACIONAL, 1998. Disponível em: <http://pfdc.pgr.mpf.mp.br/atuacao-e-conteudos-deapoio/legislacao/segurancapublica/estatuto_roma_tribunal_penal_internac ional.pdf >. Acesso em: 20 fev. 2018.

ESTÓRIA. In: DICIONÁRIO Online Caldas Aulete. [s.I]: Lexikon Editora Digital, 2016. Disponível em: <http://www.aulete.com.br/estória>. Acesso em: 21 maio 2018. 
FASOLT, C. The limits of history. Chicago: University of Chicago Press, 2004.

FISHER, K. Transitional justice for Child Soldier: accountability and social reconstruction in post-conflict contexts. Nova York: Palgrave Macmillan, 2013.

FOUCAULT, M. Microfísica do Poder. 5.ed. Organização Roberto Machado. Rio de Janeiro: Paz e Terra, 2017.

GUYOT-DIANGONE, J. Brief literature review of resilience and the child soldier. 2012. Disponível em: <https://howard.academia.edu/JulieGuyot> Acesso em: 20. nov 2016.

HANSEN, L. Discourse analysis, identity, and foreign policy. In: Security as Practice: Discourse Analysis and the Bosnian War. Nova York: Routledge, 2006. p. 15-32.

HANSON, K. Embracing the past: 'been', 'being' and 'becoming' children. Childhood, vol. 24, n. 3, p. 281-285, 2017.

HOWELL, A. The demise of PTSD: from governing through trauma to governing resilience. Alternatives: Global, Local, Political, v.37, n.3, p.214-226, 2012.

HIGONNET, A. Pictures of the innocence: the history and crisis of ideal childhood. New York: Thames and Hudson, 1998.

HUMAN RIGHTS WATCH. Forgotten Fighters: Child Soldiers in Angola. New York, 2003.

INAYATULLAH, N. Falling and flying: an introduction. In: INAYATULLAH, N. (Ed.) Autobiographical International Relations: I, IR. London: Routledge, 2011. p. 1-12.

INTER-AGENCY STANDING COMMITTEE. IASC Guidelines on mental health and psychosocial support in emergency settings. Geneva: IASC, 2007.

INTERNATIONAL RESILIENCE PROJECT. Project report 2006.

Canada, 2006. Disponível em:

<http://resilienceresearch.org/research/projects/international-

resilience\#publications > Acesso em: 7.ago 2017.

JAMES, A. Understanding childhood from an interdisciplinary perspective. In: PUTFALL, P, B.; UNSWORTH, R, P. (Eds). Rethinking childhood. New Brunswick: Rutgers University Press, 2004, p. 25-37.

JAMES, A.; PROUT, A. A new paradigm for the sociology of childhood? Provenance, promise and problems. In: (Eds.) Constructing and 
Reconstructing Childhood: Contemporary issues in the sociological study of children. London: Falmer Press, 1991. p. 7-34.

JENKS, C. Constituting Childhood. In: Childhood. London: Routledge, 2005. p. 1-28.

JÉZÉQUEL, J. Child soldiers in Africa: a singular phenomenon? Centre de réflexion sur l'action et les savoir humanitaires, n.89, p. 99-108, 2006.

KALDOR, M. New and Old Wars: organized violence in a global era. California: Stanford University Press, 2001.

KLASEN, F. et al. Posttraumatic resilience in former Ugandan child soldiers. Child Development, v.81, n.4, p. 1096-1113, 2010.

LEE, N. Childhood and Society: Growing up in an age of uncertainty. Maidenhead: Open University Press, 2001.

LEE-KOO, K. Children and peace building: propagating peace. In: D'COSTA, B.; HUYNH, K.; LEE-KOO, K. (Eds.) Children and Global Conflict. Cambridge: Cambridge University Press, 2015.p.185-209.

LIEUTENANT-GENERAL THE HONOURABLE ROMÉO A. DALLAIRE. Biography. Disponível em: <http://www.romeodallaire.com/> Acesso em: 02 set. 2017.

MACCALLIN, M. Child development and resilience. In: NOSWORTHY, D. (Ed.). Seen, but not heard: placing children and youth on the security governance agenda. Berlim: LIT VERLAG, 2009.p. 55-79.

MAGID, B.; BOOTHBY, N. Promoting resilience in children of war. In: FERNANDO, C.; FERRARI, M. (Eds.). Handbook of resilience in children of war. New York: Springer, 2013. p. 39-49

MACHEL, G. Promotion and protection of the Rights of Children: Impact of armed conflict on children. Report of Graça Machel, expert of the Secretary General of the United Nations, Nova York, A/50/60, 1996.

MACMILLAN, L. The Child Soldier in North-South Relations, International Political Sociology, v.3, n.1, p.36-52, 2009.

MASTEN, A. Global perspective on resilience in children and youth. Child Development, v. 85, n. 1, p. 6-20, 2014.

MASTEY, D. Child soldier stories and their fictions. Interventions: International Journal of Postcolonial Studies, v.18, n.1, p. 143-158, 2016.

MCKAY, S. Girlhoods stolen: the plight of girl soldiers during and after armed conflict. In: BOOTHBY, N.; STRANG, A.; WESSELLS, M. (Eds.) 
A World Turned Upside Down: Social ecological Approaches to Children in War Zones. Kumarian Press, 2006. p.89-110.

MILLIKEN, J. The study of discourse in International Relations: a critique of research and methods. European Journal of International Relations, v.5, n.2, p. 225-254, 1999.

MUTUA, M. Savages, victims, and saviors: the metaphor of human rights. Harvard International Law Journal, v. 42, n. 1, p.201-245, 2001.

NOSWORTHY, D. (Ed.). Seen, but not heard: placing children and youth on the security governance agenda. Berlim: LIT VERLAG, 2009.

OVUGA et al. Post-traumatic stress disorder among former child soldiers attending a rehabilitative service and primary school education in Northern Uganda. African Health Sciences, v.8, n.3, p. 136-141, 2008.

PETERS, K.; RICHARDS, P. Why we fight: voices of youth combatants in Sierra Leone. Africa, v. 68, n.2, p. 183-210, 1998.

PUPAVAC, V. Misanthropy without borders: the international Children's Rights Regime. Disasters, v.25, n.2, p.95-112, 2001.

QVORTRUP, J. Childhood as a structural form. In: QVORTRUP, J.; CORSARO, W; HONIG, M.S. (Eds.). The Palgrave Handbook of Childhood Studies. Houndmills: Palgrave, 2009. p. 21-33.

Editorial: The waiting child. Childhood, v.11, n.3, p.267-273, 2004.

RANCIÈRE, J. A partilha do sensível: estética e política. 2.ed. Tradução Mônica Costa Netto. São Paulo: Editora 34, 2009.

ROMÉO DALLAIRE CHILD SOLDIERS INITIATIVE. Centre for Foreing Policy Studies. Child soldiers: a handbook for security sector actors. Halifax: Dalhousie University, 2012.

ROSEN, D. Who is a child? The legal conundrum of child soldiers. Connecticut Journal of International Law, v.25, n.1, p.81-118, 2009.

Armies of the Young: Child soldiers in war and terrorism. New Jersey: Rutgers University Press, 2005.

ROSEN, S. M.; ROSEN, D. Representing Child Soldiers in Fiction and Film. Peace Review: A Journal of Social Justice, v.24, n.3, p.305-312, 2012.

SHAPIRO, J. M. Studies in trans-disciplinary method: after the aesthetic turn. London, New York: Routledge, 2013.

Methods and Nations: Cultural Governance and the Indigenous Subject. Nova York: Routledge, 2004. 
SHAPIRO, J. M. The politics of representation: writing practices in biography, photography, and policy analysis. The University of Wisconsin Press, 1988.

Politics and time. Cambridge: Polity Press, 2016.

SHARKEY, D. Picture the child soldiers. Peace Review: A Journal of Social Justice, v. 24, n.3 p. 262-267, 2012.

SHEPLER, S. Learning "child soldiers" across contexts. Informal reintegrators, communities, and NGOs. In: Childhood deployed: remaking child soldiers in Sierra Leone. New York: New York University Press, 2014. p. 81-99. p. 101-130.

SHERATT, Y. Continental philosophy of social science: hermeneutics, genealogy and critical theory from Ancient Greece to the twenty-first century. Cambridge: Cambridge University Press, 2006.

SINGER, P.W. Caution: children at war. Disponível em:

$<$ http://ssi.armywarcollege.edu/pubs/parameters/Articles/2010winter/Singe r.pdf >. Acesso em: 06 mar. 2018.

. Children at War. California: University of California Press, 2006.

SMALL ARMS SURVEY. Weapons and markets. Disponível em: <http://www.smallarmssurvey.org/weapons-and-markets/transfers.html>. Acesso em: 20 fev. 2018.

SPIVAK, G.C. Pode o Subalterno Falar? Tradução Sandra Regina Goulart Almeida, Marcos Pereira Feitosa e André Pereira Feitosa. Belo Horizonte: Editora UFMG, 2014.

STARK, L.; WESSELLS, M. The fallacy of the ticking time bomb: resilience of children formerly recruited into armed forces and groups. In: FERNANDO, C.; FERRARI, M. (Eds.). Handbook of resilience in children of war. New York: Springer, 2013. p. 95-106.

STEPHENS, S. Introduction. In: STEPHENS, S. (Ed.) Children and the Politics of Culture. Princeton: Princeton University Press, 1995. p.3-48.

SUMMERFIELD, D. The invention of post-traumatic stress disorder and the social usefulness of a psychiatric category. BMJ Clinical Research, v. 322, p. 95-98, 2001.

TABAK, J. As vozes de ex- crianças soldado: reflexões e críticas sobre o Programa de Desarmamento Desmobilização e Reintegração das Nações Unidas. Rio de Janeiro, 2009. 169 f. Dissertação (Mestrado em Relações Internacionais) - Departamento de Relações Internacionais, Pontifícia Universidade Católica do Rio de Janeiro. (PUC-Rio). 
TABAK, J. In the best interest of whom? Rethinking the limits of the international order through the (re)constructions of the world child and childsoldiers. Rio de Janeiro, 2014. 218 f. Tese (Doutorado em Relações Internacionais) - Departamento de Relações Internacionais, Pontifícia Universidade Católica do Rio de Janeiro. (PUC-Rio).

TAPIA, F. S., CIDONCHA GONZÁLEZ, R. M. Reporte internacional anual 2012 sobre la infancia afectada por la guerra: los dos congos de la guerra, 2012. Disponível em:

$<$ http://resourcecentre.savethechildren.se/content/library/documents/report e-internacional-anual-2012-sobre-la-infancia-en-la-guerra-los-dos-co>. Acesso em: 20 fev. 2018.

THE LANCET. Editorial: The hidden health trauma of child soldiers. The Lancet, v.363, p. 831, 2004.

The trauma of war in Sierra Leone. The Lancet, v.355, p. 20672068, 2000.

THE ROMÉO DALLAIRE CHILD SOLDIERS INITIATIVE. Annual report 2016. Canada, 2016.

TOL, W. A. et al. Promoting mental health and psychosocial well-being in children affected by political violence: Part I - current evidence for an ecological resilience approach. In: FERNANDO, C.; FERRARI, M. (Eds.). Handbook of resilience in children of war. New York: Springer, 2013. p.11-27.

UNICEF. Cape Town principles and best practices. Adopted at the Symposium on The Prevention of Recruitment of Children into Armed Forces and on Demobilization and Social Reintegration of Child Soldiers in Africa, Cape Town: UNICEF, 1997. Disponível em: <http://www.unicef.org/emerg/files/Cape_Town_Principles(1).pdf>. Acesso em: 20 fev. 2018.

The Paris Principles: Principles and Guidelines on Children Associated with Armed Forces or Armed Groups. Paris: UNICEF, 2007a. Disponível em: $<$ http://www.unicef.org/emerg/files/ParisPrinciples310107Eng-lish.pdf>. Acesso em: 20 fev. 2018.

Will you listen? Young voices from the conflict zone. Geneva: UNICEF, 2007b.

The State of the World's Children. New York: UNICEF, 2016.

Adult Wars, Child Soldiers. Geneva: United Nations, 2002. 
UNICEF. Psychosocial support and well-being, 2011. Disponível em: <https://www.unicef.org/protection/57929_57998.html> Acesso em: 10 ago.2017.

UNITED NATIONS (UN). Convention on the Rights of the Child, 20 nov. 1989, United Nations, Treaty Series, vol. 1577, p. 3. Disponível em: <http://www.refworld.org/docid/3ae6b38f0.html> Acesso em: 20 fev. 2018.

. Optional Protocol to the Convention on the Rights of the

Child on the Involvement of Children in Armed Conflict, 25 maio 2000. Disponível em: <http://www.refworld.org/docid/47fdfb180.html> Acesso: 20 fev. 2018.

UPRICHARD, E. Children as 'being and becomings': children, childhood and temporality. Children \& Society, vol. 22, p.303-3013, 2008.

VAN DIJK, J. Free the victim: a critique of the western conception of victimhood. International Review of Victimology, v.16, p. 1-33, 2009.

VERHEY, B. Child soldiers: preventing, demobilizing and reintegrating. Africa Region Working Paper Series. n. 23, Washington, DC: Banco Mundial, 2011.

WATSON, A. M. S. Resilience is its own resistance: the place of children in post-conflict settlement. Critical Studies on Security, v.3, n. 1, p. 47-61, 2015.

WESSELLS, M. Child Soldiers: From Violence to Protection. Massachusetts: Harvard University Press, 2006.

. Child soldiers, peace education, and postconflict reconstruction for peace. Theory into Practice, v.44, n.4, p. 363-369, 2005.

WEST, H. Girls with Guns: Narrating the Experiences of War of Frelimo's "Female Detachment". In: BOYDEN, J.; DE BERRY, J. (Eds.) Children and Youth on the Front Line: Ethnography, Armed Conflict, and Displacement. New York: Berghahn Books, 2004. p. 105-129.

WOODHEAD, M. Child Development and the Development of Childhood. In: QVORTRUP, J.; CORSARO, W.; HONIG, M.S. (Eds.). The Palgrave Handbook of Childhood Studies. Houndmills: Palgrave, 2011. p.46-61.

YNGVESSON, B. The child who was left behind: 'Dynamic temporality' and interpretations of history in transnational adoption. Childhood, v.20, n. 3, p. 354-367, 2013.

ZACK-WILLIAMS, T. When children become killers: child soldiers in the civil war in Sierra Leone. In: FERNANDO, C.; FERRARI, M. (Eds.). Handbook of resilience in children of war. New York: Springer, 2013. p.83-106. 


\section{Referências visuais}

Children of Conflict: República Democrática do Congo (Parte I). Produção Rede Aljazeera. Documentário, 12 min. 08 s., 2007. Disponível em: <https://www.youtube.com/watch?v=kpd3ykS4QOQ> Acesso em 07 mar. 2018.

. (Parte II). Documentário, 11 min. 38 s., 2007. Disponível em: <https://www.youtube.com/watch?v=BwSa1BGBMjs > Acesso em 07 mar. 2018.

Beats of No Nation. Produção Amy Kaufman, Riva Marker e Daniela Taplin Lundberg, direção de Cary Joji Fukuhaga. Filme original da Netflix. Disponível online em sua plataforma, 2015, 137 min. color. son.

Shapiro. Direção e produção: Isabela Carpena. Documentário, 41min. 42s., 2015. Disponível em: <https://www.youtube.com/watch?v=cAPNJc6yVBQ > Acesso em: 9 ago. 2016. 